Portland State University

PDXScholar

Summer 10-10-2014

\title{
The Ground Slate Transition on the Northwest Coast: Establishing a Chronological Framework
}

Joshua Daniel Dinwiddie

Portland State University

Follow this and additional works at: https://pdxscholar.library.pdx.edu/open_access_etds

Part of the Anthropology Commons

Let us know how access to this document benefits you.

Recommended Citation

Dinwiddie, Joshua Daniel, "The Ground Slate Transition on the Northwest Coast: Establishing a Chronological Framework" (2014). Dissertations and Theses. Paper 2076.

https://doi.org/10.15760/etd.2075

This Thesis is brought to you for free and open access. It has been accepted for inclusion in Dissertations and Theses by an authorized administrator of PDXScholar. Please contact us if we can make this document more accessible: pdxscholar@pdx.edu. 
The Ground Slate Transition on the Northwest Coast:

Establishing a Chronological Framework

\author{
by \\ Joshua Daniel Dinwiddie \\ A thesis submitted in partial fulfillment of the \\ requirements for the degree of
}

Master of Science
in
Anthropology

Thesis Committee:

Kenneth M. Ames, Chair

Shelby L. Anderson

Virginia L. Butler

Portland State University

2014 
(C) 2014 Joshua Daniel Dinwiddie 


\section{Abstract}

This thesis establishes the earliest appearance of ground slate points at 50 locations throughout the Northwest Coast of North America. Ground slate points are a tool common among maritime hunter-gatherers, but rare among hunter-gatherers who utilize terrestrial subsistence strategies; ground slate points are considered one of the archaeological hallmarks of mid-to-late Holocene Northwest Coast peoples. The appearance of ground slate points in the archaeological record is frequently marked by a concurrent decline in the prevalence of flaked stone points, a phenomenon often referred to as "the ground slate transition." Until now, the specific timing of the appearance of these tools has been ill-defined, and a number of competing theories have arisen to explain the apparent preference for ground slate points over flaked points by prehistoric peoples. By drawing upon a sample of 94 artifact assemblages from 50 sites in Alaska, British Columbia, and Washington, I have constructed a database of artifacts counts, provenience information, and radiocarbon dates which allows for inter-site comparisons of the earliest appearance of the technology. My research has identified a general north to south trend in the appearance of slate points; which begin to appear in the archaeological record around 6,300 cal BP in southeast Alaska, to 2,900 cal BP in Puget Sound. There are notable exceptions to this pattern, however. Given that these data are drawn from both cultural resource management reports and academic literature, I have qualified these findings by addressing some of the common problems of making inter-site comparisons, such as the comparability of radiometric dates, which I address by undertaking a radiocarbon hygiene program. The chronology constructed here provides an important tool for evaluating theories about the ground slate transition, and thereby aiding in untangling the link between aquatic subsistence strategies and technological decision making. 
For Anna. 


\section{Acknowledgements}

This thesis would not have been possible without the help and guidance of many people. First, I would like to thank the faculty and staff at Portland State University, especially Connie Cash, who was always so kind to expedite my invariably late paperwork. Thanks also to my cohort, for all the camaraderie and long evening discussions. Thanks to Diana Cooper and the staff at the British Columbia Archaeology Branch, who provided invaluable assistance in compiling many of the reports used in this thesis. And of course, the warmest of thanks go to my committee; thanks to Dr. Shelby Anderson, for both agreeing to serve on my committee, and giving me my start in professional archaeology out on the Alaskan tundra. Thanks also to Dr. Virginia Butler, who through her instruction and comments taught me to think like a scientist. And of course thanks to Dr. Ken Ames, who taught me to write like a scientist; and for his guidance and wellspring of knowledge. Thank you to my parents John and Annie, for their love and support, and for making my graduate career possible. Finally and foremost, I would like to thank my wife and indefatigable editor Anna, whose years of love, patience, and wise counsel helped bring this thesis to fruition. 


\section{Table of Contents}

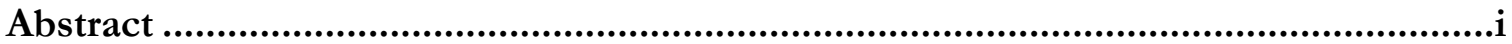

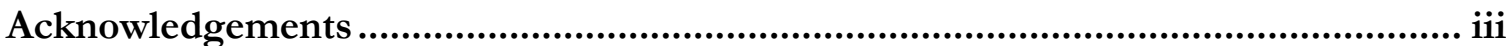

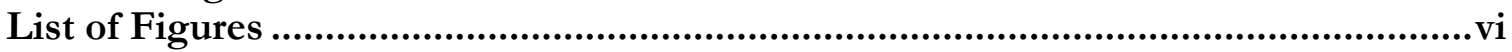

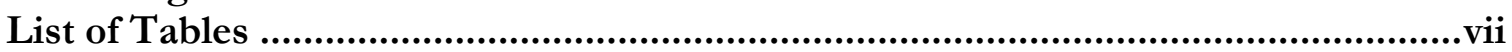

Chapter 1: Introduction ...................................................................................... 1

1.1 What Are Ground Slate Points? ...................................................................4

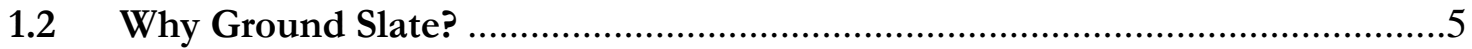

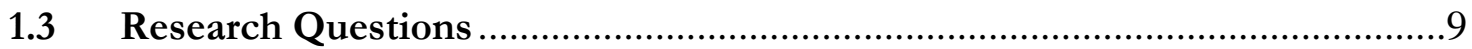

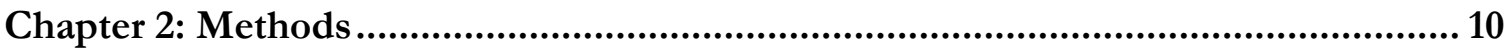

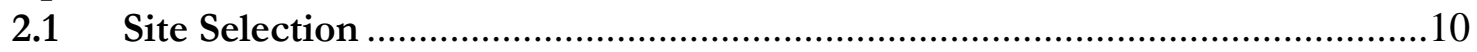

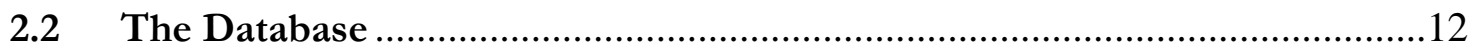

2.3 Radiocarbon Calibration and Hygiene ................................................ 17

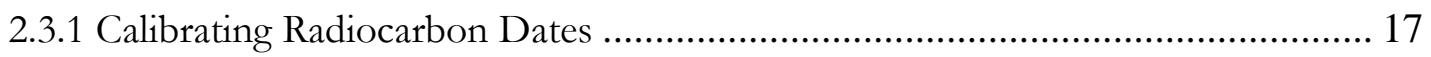

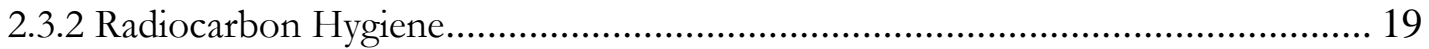

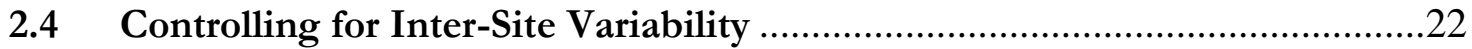

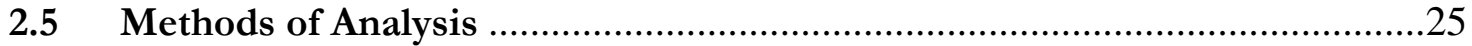

2.5.1 Inter-Site Comparability Analyses .................................................................. 25

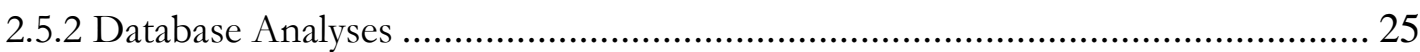

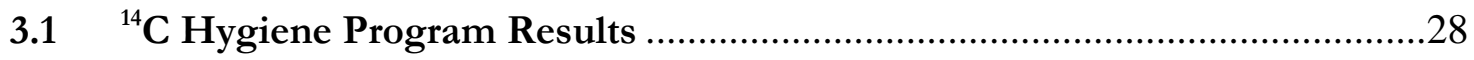

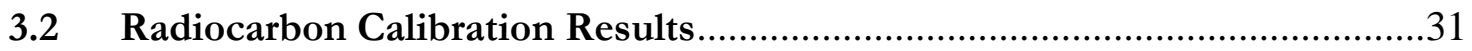

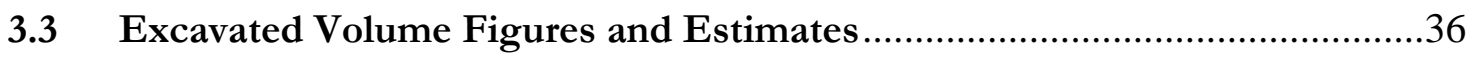

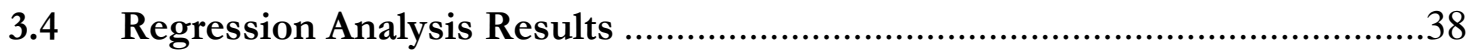

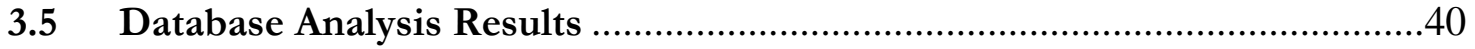

3.6 A Comparison of the Earliest Ground Slate Point Dates and Geography .....43

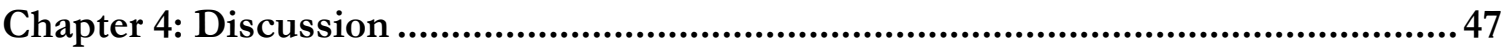

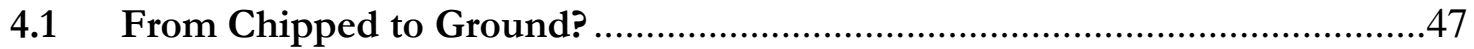

4.2 The Appearance of Ground Slate on the Northwest Coast .........................50

4.3 Is Absence of Evidence Really Evidence of Absence? ..................................52

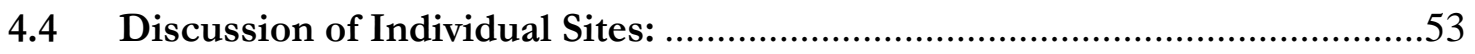

4.4.1 The Northern Study Area: Kodiak Island to Haida Gwaii ............................... 53

4.4.2 The Southern Study Area: Vancouver Island, the Salish Sea, and the Fraser River

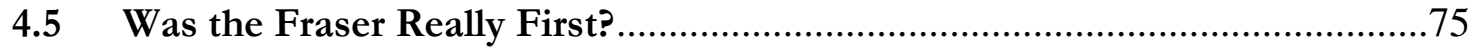




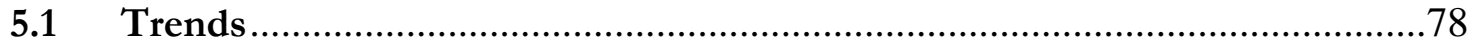

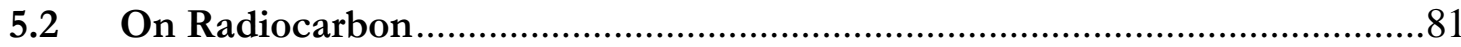

5.3 Implications, Speculations, and Future Directions .................................83

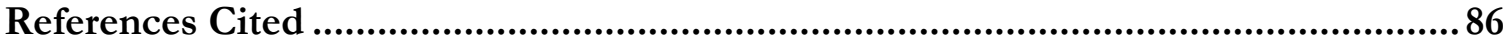

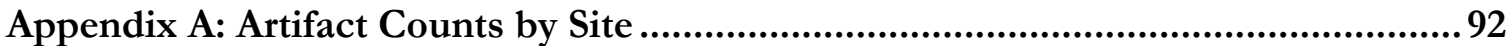




\section{List of Figures}

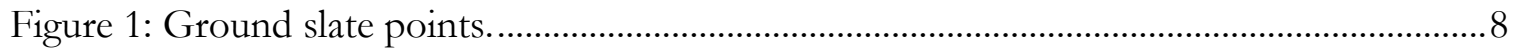

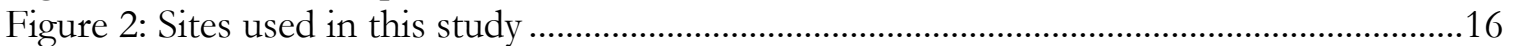

Figure 3: Frequency distribution of radiocarbon hygiene scores for $14 \mathrm{C}$ dates .......................29

Figure 4: Regression analysis for area and ground slate points recovered.................................3

Figure 5: Regression analysis for volume and ground slate points recovered............................39

Figure 6: Bar chart showing the earliest occurrence of ground slate points for all sites. ........44

Figure 7: Bar chart showing the earliest occurrence of ground slate points, with ground slate

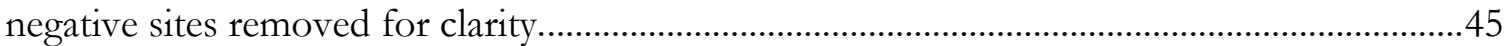

Figure 8: Bar chart showing the earliest occurrence of ground slate points for all sites, based

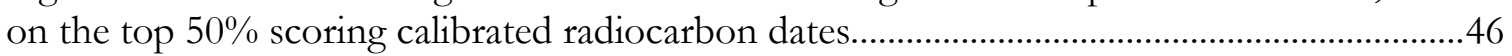

Figure 9: Geographic trends in the abundance of slate points versus flaked stone points. ....49

Figure 10: Radiocarbon calibration probability distribution for sites in Southeast Alaska .....53

Figure 11: Radiocarbon calibration probability distribution for sites in Prince Rupert Harbor

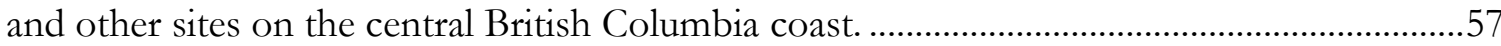

Figure 12: Radiocarbon calibration probability distribution for sites on Haida Gwaii (Queen

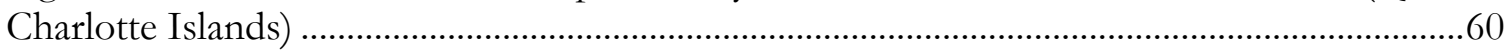

Figure 13: Vancouver Island, the Strait of Georgia and Fraser River sites showing the

median earliest date (two sigma) associated with ground slate points........................................63

Figure 14: Vancouver Island, the Strait of Georgia and Fraser River sites showing the earliest

date (two sigma) associated with ground slate points...........................................................64

Figure 15: Radiocarbon calibration probability distribution for sites on the Fraser River......68

Figure 16: Radiocarbon calibration probability distribution for sites on the east coast of

Vancouver Island and other sites in the Salish Sea ................................................................. 70

Figure 17: Radiocarbon calibration probability distribution for sites on the west coast of

Vancouver Island 


\section{List of Tables}

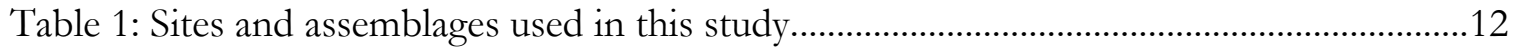

Table 2: Scoring criteria for confidence in radiometric samples .................................................22

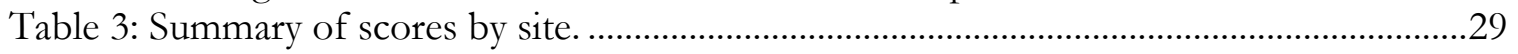

Table 4: Calibrations of the 69 radiocarbon samples used for analysis in this work.................32

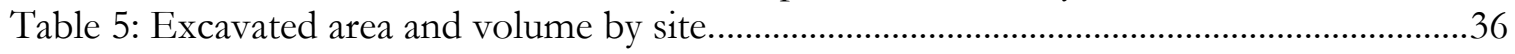

Table 6: Presence or absence of ground slate points by site and component...........................40

Table 7: Relative proportions of slate points, slate knives, and flaked points for sites in the

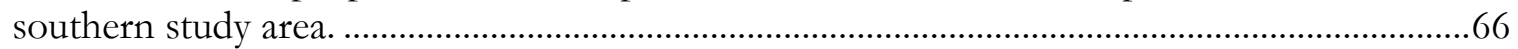

Table 8: Comparison of Components: Duke Point (DgRx-5) and Deep Bay (DiSe-7)..........72 


\section{Chapter 1: Introduction}

Ground stone tools begin to appear globally during the Holocene, and this thesis is concerned specifically with the earliest appearance of one such type of tool, ground slate points, on the Northwest Coast of North America. Archaeologists on the Northwest Coast have for decades remarked on the "ground slate transition", a general trend common throughout the region of flaked stone tools being replaced by functionally similar tools made of ground slate. In spite of years of speculation as to the causes and effects of this transition, (e.g. Ames 2009; Borden 1962; Clark 1982; Dumond 1968; Fitzhugh 2004; Moss 2004; Ritchie 1969) the spatiotemporal patterning of the appearance and spread of ground slate points remains murky. Generally speaking, slate points begin to supplant comparable chipped stone technologies in the archaeological record by the Early Pacific period (6,3503,750 BP). By the Middle Pacific (3,750- 1,750 BP), ground slate points are an even greater part of the Northwest Coast hunter-gather toolkit. However, the variability in the decline of chipped stone tools relative to ground stone is poorly understood during this period (Ames and Maschner 1999:94) The Middle Pacific was a period of increasing technological diversification, evidenced not only by increasing numbers of slate tools, but also by the introduction of complex, blade-armed socket harpoons. This fact has important implications for this study, as slate points are not complete tools in and of themselves, rather they are commonly thought to have been used to arm composite tools (such as socket harpoons) that were developed specifically for marine mammal hunting. I will return to the link between ground slate points and aquatic subsistence strategies below.

There was also considerable regional variability in the use of ground slate points during the Early and Middle Pacific periods. In some areas of the Northern Coast (Southeast 
Alaska, British Columbia’s Prince Rupert Harbor), ground slate technology is found in abundance during the Early Pacific. In addition to slate points, other grounds stone tools such as adzes and abraders, as well as non-utilitarian items such as pendants and labrets are also common. Conversely, during the same period at sites like Namu, on the Central Coast, ground slate tools are comparatively rare.

While this thesis is concerned primarily with ground slate points within the context of Northwest Coast assemblages, they are in fact a maritime phenomenon, and not just a Northwest Coast one. Slate points can also be found in assemblages from the Aleutian Islands, the Bering Sea, and even the Eastern Arctic. Dumond (1987) remarks that long slate points are a hallmark of early $(\sim 4,500-3,500 \mathrm{BP})$ Kodiak assemblages. Slate points are somewhat less common, and appear considerably later in the western Aleutians, appearing sometime around 1,000 BP (Hatfield 2010). Slate points also appear somewhat late in the higher latitudes, appearing in small numbers in Choris $(\sim 3,000-2,500 \mathrm{BP})$, Norton $(\sim 2,500$ 1,900 BP), Ipiutak ( 2,000-1,500 BP) assemblages, and eastern arctic Dorset assemblages at around $\sim 2,800$ BP. Slate points do not become a significant part of the arctic toolkit until the Thule phase, 950 BP (Dumond 1987).

As was alluded to above, the appearance of ground slate points is often associated with an increase in aquatic subsistence activities, as well as increasing sedentism among hunter-gatherers (Ames 2009; Ames and Maschner 1999; Clark 1982; Fitzhugh 2001) In all of these regions, the fluorescence of slate tools coincides with an increased use of maritime resources (Ames and Maschner 1999; Dumond 1987; McGhee 2001). Further, archaeologists assume the spatiotemporal distribution of ground slate points is linked to maritime economies due to the prevalence of ground slate points along the coast, compared with their 
exceptional rarity in contemporary interior sites (Clark 1982:110). As such, the ground slate transition would seem to have important implications for the study of hunter-gatherer maritime adaptations and economies.

The study of aquatic adaptation in hunter-gather societies began in earnest with the development of the "New Archaeology" in the 1960's, which provided the theoretical structure within which discussions of hunter-gatherer economies could be framed (Erlandson 2001). These early "New Archaeology" ideas of the role of aquatic resources among hunter-gathers can broadly be described as falling into one of two camps, which Erlandson (2001:290) characterizes the "Garden of Eden" and "Gates of Hell” models. “Garden of Eden" adherents (Cutting 1962; Sauer 1962) contended that aquatic environments provided a reliable, essentially inexhaustible source of nutrition, whereas “Gates of Hell” proponents (Bailey 1978; Cohen 1977) considered aquatic resources to be starvation food for hunter-gatherer peoples, an unfamiliar, low-ranking source of last resort. The general consensus now among researchers on the Northwest Coast is that aquatic resources were not merely important to hunter-gatherers in near-shore environments, they were perhaps the central pillar around which their societies were based (Erlandson 2001; Matson and Coupland 1995; Renouf 1991; Yesner 1980, 1987). For example, Ames (2002) notes that compared to terrestrial hunter-gatherers, aquatic hunter-gathers tend to have higher population densities, and greater degree of sedentism, and frequently form more socially and economically complex societies. There is clearly a link between aquatic adaptation and social complexity (e.g. Arnold 1992; Erlandson 2001), but the question arises, is it a causal link? It is my intent with this thesis to establish a fine-grained chronology of the earliest appearance of ground slate points in the archaeological record of the Northwest 
Coast (from Kodiak Island to Puget Sound for the purposes of this study). The intent being to provide a framework that can then be correlated with other lines of evidence (e.g. huntergatherer diet data derived from faunal assemblages, sea level data, other technological studies, etc.) to help untangle the relationship between aquatic resources and social complexity.

\subsection{What Are Ground Slate Points?}

Ground slate points are piercing implements, usually bifacially worked from "sawnand-snapped" blanks or "beach-rolled bars" (Clark 1982), naturally occurring tabular pieces of slate smoothed by wave action. These raw slate bars are then made into points by scraping, grinding on abrasive stones, or more rarely by initially chipping large pieces of the material away, and then grinding or scraping the product (Clark 1982). Little has been published on ground slate tool manufacture, but Moss (2004), discussing unpublished experiments conducted by Jon Erlandson, contends that while large slate points require considerable manufacturing effort, slate possesses a number of advantages over the cryptocrystalline materials used to make chipped stone tools. For example, slate tools suffer fewer manufacturing failures, and the finished product is more durable. Erlandson concluded that a chipped stone point is more likely to shatter when dropped, while a ground slate point may chip, but can be re-sharpened through grinding. This is in contrast to earlier notions about the functional properties of slate points. Clark (1982) contends that while slate cannot be proven to have an advantage over flaked stone points when hunting on the water, on land it has a distinct disadvantage, supposing that a slate point which misses its target is more likely to suffer a broken tip. 
Ground slate point morphology is highly variable for a number of reasons; foremost, slate points have been used in a variety of weapons systems, (e.g. many different types of compound harpoon heads, arrows, lances, etc.) accordingly, they are also regionally variable (as different regions preferred different weapons systems). In Southeast Alaska, slate points are frequently bayonet-shaped; both stemmed and unstemmed are common. In the Gulf of Georgia and Puget Sound regions, triangular and bipointed points are the most common forms. Slate point morphology is also temporally patterned. Much like flaked stone projectile points, later period slate points are frequently smaller than earlier points. See Figure 1.

This study looks specifically at slate points (hafted piercing implements), and not ground slate technology in a more general sense (e.g. objects such as transverse ground slate knives and salmon knives) though both are often lumped into a package of traits known as the "Developed Northwest Coast Pattern" (Matson and Coupland 1995). While produced by a similar process, ground slate knives and points serve different functions. Slate knives were commonly used for tasks such as filleting fish, as slate tools can be made very thin, and their smooth cutting edge is less likely to damage the delicate meat than a flaked edge (Clark 1982). On the other hand, slate points are used primarily for food procurement, rather than processing. In this sense, slate points are functionally analogous to earlier flaked stone points, and accordingly make an ideal case study for examining what factors drive technological change.

\subsection{Why Ground Slate?}

Many more theories have been developed to address the invention or adoption of new technologies among hunter-gatherers, and a few hypotheses more specifically address the archaeological significance of the appearance of ground slate points on the Northwest 
Coast. I will briefly outline three of these general theories of technological change (from farreaching to more specific), as well as discussing some general ideas common to a number of theories about the cause of the ground slate transition.

Bamforth and Bleed (1997) espouse a selectionist (i.e. Darwinian) approach to understanding why new technologies are adopted. Very briefly, the selectionist approach argues that changes in human behavior (tool making, in this example) are the result of a differential persistence of one kind of behavior or artifact variant over another, with successful artifact types "selected" by external (often environmental) conditions. Bettinger et al. (2006), when considering the same question (what causes changes in technology) instead frame the problem in economic terms, by considering the ratio of time and resource investment to the expected (and actual) return on that investment. They argue that new technologies only persist when this return is above a certain threshold. Collard et al.(2005) focus on the role of risk in explaining toolkit variation. They argue that risk of resource failure is the primary factor which makes hunter-gatherers diversify their tool kits, the idea being that high-risk scenarios will favor innovation.

With regards to the adoption of ground slate points specifically, most hypotheses can be placed into one of two camps: technological explanations (e.g., ground slate points are a superior tool, because $X$ or $Y$ ) or raw material explanations (e.g. $X$ or $Y$ has led to a differential access to non-slate tool stone). These general categories need not be mutually exclusive, however. In an example of the former, Christopher Ames (2009) proposes that the adoption of ground slate points is part of an overall pattern of resource diversification (including marine resources); whereas Clark (1982) sees their adoption as application of methods used to make bone points (e.g. sawing, scraping) to slate, without implying any 
direct economic (i.e. subsistence) implications. In the most developed example of the later, Moss (2004) suggests that the primary factor in the adoption of ground slate is the availability of the raw material. She notes that slate cobbles are readily available throughout much of the Northwest Coast, while cryptocrystalline materials were rarer. She suggests that over time, as population pressure increased along the coast, increased levels of territoriality limited access to resources such as obsidian quarries, leading to increased use of locally available slate. This theory is particularly attractive as it provides a causal explanation for the timing (not just a technological explanation) of the transition from chipped stone to ground slate.

While these researchers make good cases for their theories, I feel that they are all at present equally untenable. As the precise timing of the ground slate transition has not yet been established, correlations between the transition to other factors (such as population, or evidence of resource diversification, etc.) are tenuous at best. The goal of this thesis is to establish the when of ground slate transition, in order to evaluate these why theories more effectively. 

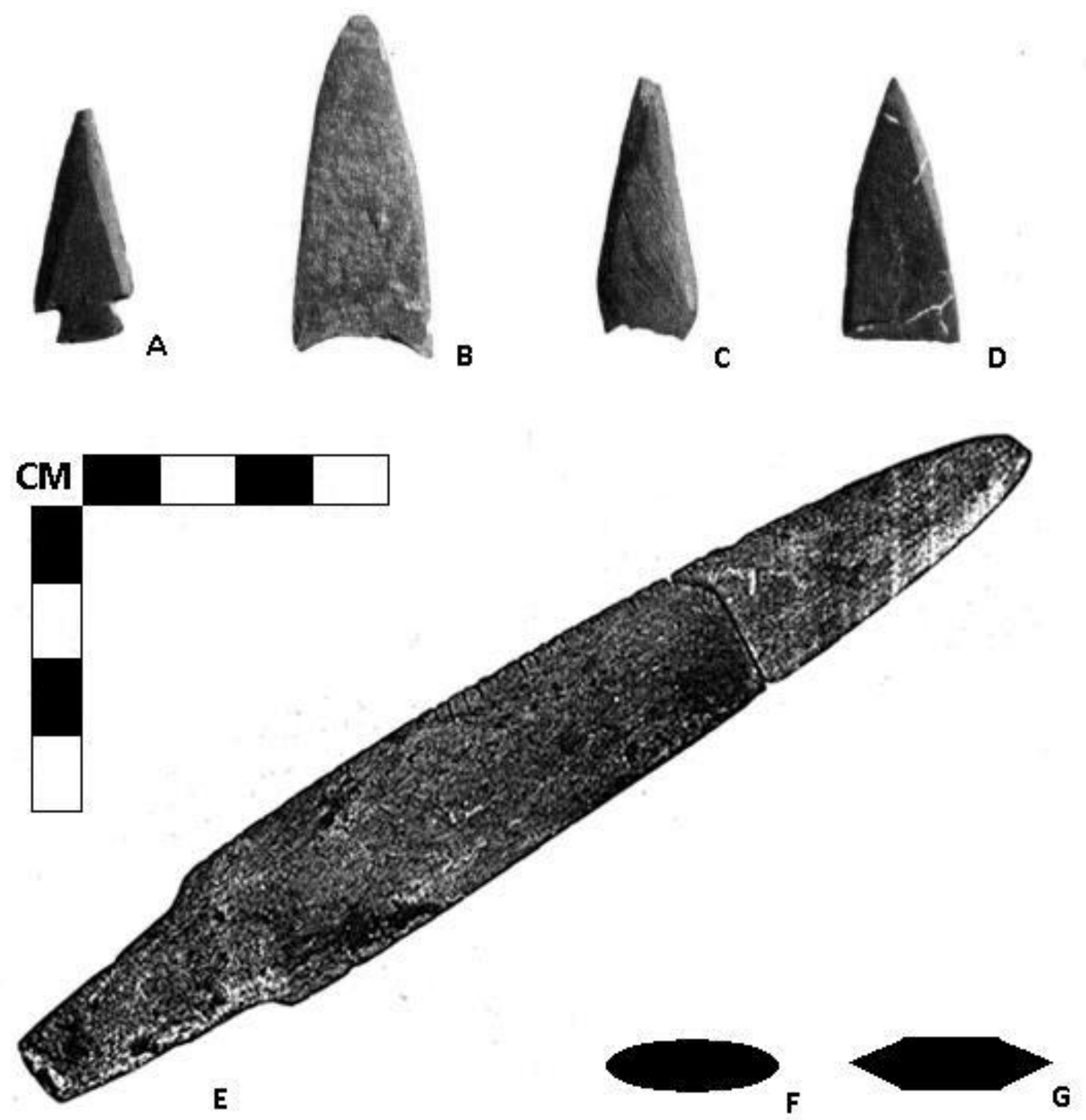

Figure 1: Ground slate points. A-D: Triangular points from Deep Bay, DiSe-7 (Monks 1977). E: Stemmed bayonet-shaped point (or lanceolate) from Hidden Falls, 49SIT119 (Clark 1979). F-G: Slate point cross sections, lenticular (F) and hexagonal (G). F-G by the author. 


\subsection{Research Questions}

The initial goal of this project to was test a number of these hypotheses regarding the adoption of ground slate points on the Northwest Coast, and more generally what drove technological change among hunter-gatherers on the whole. The reality of the ground slate transition is not in question; it is indisputable that a wide-spread adoption of the technology is apparent in the archaeological record. The problem is that these hypotheses cannot be tested given our current state of knowledge, as the chronological and geographic dimensions of the transition have never been clearly defined. Accordingly, this study is aimed at answering three distinct questions:

1. Did slate points in fact replace functionally comparable chipped stone technologies (i.e. can this appearance be properly termed a "transition")?

2. When did ground slate points first appear in the archaeological record of the Northwest Coast?

3. Further, geographic or temporal trends exist between the adoption of slate points and the decline of chipped stone technologies, either regionally or coast-wide? This project is, out of necessity, largely atheoretical. Only once the spatiotemporal patterns of ground slate points are better understood, the real task — the search for what this transition is telling us_-can begin. The Northwest Coast ground slate transition might present the ideal case study for evaluating the hypotheses of technological change outlined in section 1.2, but without foundational works such as the one proposed here, we cannot hope to answer such higher-level questions with any certainty. 


\section{Chapter 2: Methods}

Building a chronological framework for the earliest appearance of ground slate points was a multi-step process. I began by searching for archaeological site reports from southeast Alaska to the Salish Sea, and then by selecting those reports which met certain suitability criteria. The next step was to construct a Microsoft Access database of artifactual data, radiocarbon dates, and provenience data from these site reports. This database made it possible to associate each radiocarbon date with the presence or absence of ground slate points and flaked stone points at the finest level of vertical provenience available, often by component, occasionally as specific as individual strata. The collected radiocarbon dates were then subjected to a scoring process (a practice termed radiocarbon hygiene) in an effort to quantify relative confidence in both the quality of the ${ }^{14} \mathrm{C}$ assay, and the confidence that the sample is associated with the archaeological phenomena in question. This pool of radiocarbon dates was then calibrated. These calibrated dates, along with the information of whether or not they were associated with ground slate points, were then used to construct floating bar plots which illustrate the geographic and temporal parameters of the earliest occurrence of ground slate points for these sites. Further work, such as estimating excavated volumes for these sites, was needed to assure that the data used in this study were both comparable and representative of the assemblages from which they were drawn.

\subsection{Site Selection}

In order to find site reports for this study, I utilized three primary repositories: the Portland State University Library/SUMMIT/interlibrary loan, the British Columbia Provincial Archaeological Reports Library (PARL), and the personal library of Dr. Kenneth Ames. These sources allowed me to utilize both university-produced site reports as well as 
cultural resource management reports. Sites were selected for this study using three primary criteria: 1 sites with a sufficient time depth to potentially have both a chipped stone and ground slate component; 2 . assemblages of a sufficient size to allow performing simple statistical tests (greater than fifty combined chipped and ground slate points, ideally); and 3. reliable radiometric dates, since without chronological controls, the timing of the transition cannot be established. It is worth noting that not all technologies employed by a particular people are to be found in all of their sites. This fact is especially relevant to this study, given the collector-oriented economies of Northwest Coast peoples, with specific tool kits associated with particular sites (i.e. residential bases, field camps, caches, etc.) (Binford 1980). I have endeavored to represent as many of these site types as possible when selecting sites for this study, but the sample is no doubt weighted towards habitation sites, given the large assemblage size requirements. Site selection was also constrained by the availability of reports; some regions are better studied than others (i.e. Vancouver Island or Puget Sound, where cultural resource management work has produced an abundance of research) and some reports can be accessed more easily than others. For these reasons, parts of southeast Alaska (e.g. the Alexander Archipelago) are unfortunately underrepresented in this study. Archaeological records were requested from PARL on a regional basis; the staff there will provide reports for a given Borden block. As such, not all reports returned to me were included in the database, many did not meet the criteria outlined above (i.e. no radiocarbon dates reported, too little excavated area to have yielded any tools, etc.). While records were not kept of how many site reports were examined and found to be unsuitable for analysis in this study, I would estimate that something like $50 \%$ of the reports I examined were not suitable for my purposes (e.g. no slate points, no provenience information, or no 
radiocarbon dates). While my site selection process was not systematic or exhaustive, I feel that it represents a large enough sample (94 components from 50 sites) from which to draw valid conclusions. Table 1 contains a complete list of sources used for this study.

\subsection{The Database}

The next task in this study was the construction of a database of information from the selected reports. Site locations, geographic context (e.g. small island, large island, mainland coastal riverine, etc.), excavated volume/area, artifact counts, and basic artifact morphology were all recorded. Vertical provenience (analytic units, component, or strata) was also recorded for artifactual data. A second (linked) table for radiometric dates, vertical provenience, and positive or negative association with ground slate points was also compiled. This database contains information from 94 distinct components from a collection of 50 sites, as well as 484 radiocarbon dates. This database was then used in conjunction with geographic information systems (GIS) software, as well as spreadsheet and graphing software (Microsoft Excel) for analysis (See section 2.5).

Table 1: Sites and assemblages used in this study. Some assemblages were grouped when it was not possible to attribute ${ }^{14} \mathrm{C}$ dates to individual components.

\begin{tabular}{|c|c|c|c|c|}
\hline Site Name & Site Number & $\begin{array}{l}\text { Assemblage/ } \\
\text { Component }\end{array}$ & Phase & Source \\
\hline Baldwin & GbTo 36 & - & Prince Rupert II & Ames 2005 \\
\hline Belcarra Park & DhRr 6 & Components I-II & $\begin{array}{l}\text { Locarno-Gulf of } \\
\text { Georgia }\end{array}$ & Charlton 1980 \\
\hline Blue Jackets Creek & F1ua-4 & - & - & Severs 1974 \\
\hline Boardwalk & GbTo 31 & $\mathrm{AU} / \mathrm{S}$ & - & Ames 2005 \\
\hline Boardwalk & GbTo 31 & AU 1 & Prince Rupert III & Ames 2005 \\
\hline Boardwalk & GbTo 31 & AU 2 & Prince Rupert II & Ames 2005 \\
\hline Boardwalk & GbTo 31 & AU 3 & Prince Rupert II & Ames 2005 \\
\hline Boardwalk & GbTo 31 & AU 4 & Prince Rupert I & Ames 2005 \\
\hline British Camp & $45 \mathrm{SJ} 24$ & Ethnozone I & Marpole & Stein 1992 \\
\hline British Camp & $45 \mathrm{SJ} 24$ & Ethnozone II & Gulf of Georgia & Stein 1992 \\
\hline Buckley Bay & DjSf-13 & - & Marpole & Mitchell 1974 \\
\hline
\end{tabular}




\begin{tabular}{|c|c|c|c|c|}
\hline Site Name & Site Number & $\begin{array}{l}\text { Assemblage/ } \\
\text { Component }\end{array}$ & Phase & Source \\
\hline Cahoe Creek & FjUb 10 & Components I-III & Moresby (?) & $\begin{array}{l}\text { Fedje and Mathewes } \\
2005\end{array}$ \\
\hline Cahoe Creek & FjUb 10 & Component IV & Transitional (?) & $\begin{array}{l}\text { Fedje and Mathewes } \\
2005\end{array}$ \\
\hline Ch'uumat'a & DfSi 4 & - & West Coast (?) & $\begin{array}{l}\text { McMillan and St. Claire } \\
1994\end{array}$ \\
\hline Chert Site & 49AFO106 & Ocean Bay II & Ocean Bay II & Clark 1982 \\
\hline Chert Site & 49AFO106 & Ocean Bay I & Ocean Bay I & Clark 1982 \\
\hline Coffman Cove & 49PET067 & - & Locarno Beach & Clark 1979 \\
\hline Crescent Beach & DgRr1 & - & Locarno Beach (?) & Matson, et al. 1991 \\
\hline Decatur Island I & $45 \mathrm{SJ} 165$ & - & - & Walker 2003 \\
\hline Decatur Island II & $45 \mathrm{SJ} 169$ & Component I & - & Walker 2003 \\
\hline Decatur Island II & $45 \mathrm{SJ} 169$ & Component II & - & Walker 2003 \\
\hline Decatur Island II & $45 \mathrm{SJ} 169$ & Component III & - & Walker 2003 \\
\hline Decatur Island II & 45SJ169 & Component IV & - & Walker 2003 \\
\hline Decatur Island II & $45 S J 169$ & Component V & - & Walker 2003 \\
\hline Deep Bay & DiSe-7 & Component I & Locarno Beach & Monks 1977 \\
\hline Deep Bay & DiSe-7 & Component II & Marpole & Monks 1977 \\
\hline Deep Bay & DiSe-7 & Component III & Gulf of Georgia & Monks 1977 \\
\hline Dionisio Point & $\mathrm{DgRv}_{\mathrm{V}} 3$ & House 2 & Marpole & Grier 2002 \\
\hline Duke Point & $\operatorname{DgRx} 5$ & Component I & Locarno Beach & Murray 1982 \\
\hline Duke Point & $\operatorname{DgRx} 5$ & Component II & Marpole & Murray 1982 \\
\hline Duke Point & $\operatorname{DgRx} 5$ & Component III & Gulf of Georgia & Murray 1982 \\
\hline Esilao & DjRi-5 & Upper & - & Mitchell 1963 \\
\hline Esilao & DjRi-5 & Lower & - & Mitchell 1963 \\
\hline False Narrows & $\mathrm{DgRw} 4$ & Components III-IV & $\begin{array}{l}\text { Gulf of } \\
\text { Georgia/Historic }\end{array}$ & Burley 1989 \\
\hline FaTt 28 & FaTt 28 & Unknown & - & Acheson 1991 \\
\hline Garden Island & GbTo 23 & AU 1 & - & Ames 2005 \\
\hline Garden Island & GbTo 23 & AU Unknown & - & Ames 2005 \\
\hline Georgeson Bay & DfRu 24 & Component I & Locarno Beach & $\begin{array}{l}\text { Haggarty and Sendey } \\
1976\end{array}$ \\
\hline Georgeson Bay & DfRu 24 & Component II & Gulf of Georgia & $\begin{array}{l}\text { Haggarty and Sendey } \\
1976\end{array}$ \\
\hline Glenrose Cannery & $\operatorname{DgRr} 6$ & Old Cordilleran & Old Cordilleran & Matson 1976 \\
\hline Glenrose Cannery & $\operatorname{Dg} \operatorname{Rr} 6$ & Marpole & Marpole & Matson 1976 \\
\hline Glenrose Cannery & $\operatorname{DgRr} 6$ & St. Mungo & St. Mungo & Matson 1976 \\
\hline Grant Anchorage & Fc'Te-4 & - & - & Simonsen 1973 \\
\hline Ground Hog Bay & 49JUN018 & Component I & - & Ackerman 1968 \\
\hline Ground Hog Bay & 49JUN018 & Component II & - & Ackerman 1968 \\
\hline Hatzic Rock & DgRn-23 & Components I-III & Charles & Mason 1994 \\
\hline
\end{tabular}




\begin{tabular}{|c|c|c|c|c|}
\hline Site Name & Site Number & $\begin{array}{l}\text { Assemblage/ } \\
\text { Component }\end{array}$ & Phase & Source \\
\hline Hesquiat Village & DiSo 1 & - & - & Haggarty 1985 \\
\hline Hidden Falls & 49SIT119 & Component I & - & Davis 1989 \\
\hline Hidden Falls & 49SIT119 & Component II & - & Davis 1989 \\
\hline Hidden Falls & 49SIT119 & Component III & - & Davis 1989 \\
\hline Indian Island & 45JE16 & - & - & $\begin{array}{l}\text { Onat and Haversat } \\
1977\end{array}$ \\
\hline Katz Site & DiRj 1 & Zone A & Locarno Beach & Hanson 1973 \\
\hline Katz Site & DiRj 1 & Zone B & Locarno Beach & Hanson 1973 \\
\hline Kilgii Gwaay & $\begin{array}{l}\text { 1325T (FaTs- } \\
\text { ?) }\end{array}$ & - & - & $\begin{array}{l}\text { Fedje and Mathewes } \\
2005\end{array}$ \\
\hline Kitandach & GbTo 34 & - & - & Ames 2005 \\
\hline Lachane & GbTo 33 & - & - & Ames 2005 \\
\hline Loon Cave & DiSo 9 & - & - & Haggarty 1985 \\
\hline $\begin{array}{l}\text { Montague } \\
\text { Harbour }\end{array}$ & DfRu 13 & Component I & Locarno Beach & Mitchell 1971 \\
\hline $\begin{array}{l}\text { Montague } \\
\text { Harbour }\end{array}$ & DfRu 13 & Component III & Gulf of Georgia & Mitchell 1971 \\
\hline Narvaez Bay & $1642 \mathrm{~T}$ & - & - & Fedje, et al. 2009 \\
\hline O'Connor & EeSu 5 & Components I-III & - & Chapman 1982 \\
\hline Pitt River & DhRq-21 & Kroeker & Gulf of Georgia & Patenaude 1985 \\
\hline Pitt River & DhRq-21 & Logodi- Charles & Charles & Patenaude 1985 \\
\hline Pitt River & DhRq-21 & Logodi- Locarno & Locarno Beach & Patenaude 1985 \\
\hline Pitt River & DhRq-21 & Mackenzie- Charles & Charles & Patenaude 1985 \\
\hline Pitt River & DhRq-21 & $\begin{array}{l}\text { Mackenzie- } \\
\text { Locarno }\end{array}$ & Locarno Beach & Patenaude 1985 \\
\hline Richardson Island & $1127 \mathrm{~T}$ & - & - & $\begin{array}{l}\text { Fedje and Mathewes } \\
2005\end{array}$ \\
\hline Sequim Bypass & 45CA426 & Component II & $\begin{array}{l}\text { Locarno } \\
\text { Beach/Marpole }\end{array}$ & Morgan, et al. 1999 \\
\hline Shoemaker Bay & DhSe-2 & Component I & Marpole & $\begin{array}{l}\text { McMillan and St. Claire } \\
1982\end{array}$ \\
\hline Shoemaker Bay & DhSe-2 & Component II & Gulf of Georgia & $\begin{array}{l}\text { McMillan and St. Claire } \\
1982\end{array}$ \\
\hline Sitkalidak Roadcut & 49KOD438 & Ocean Bay II & Ocean Bay II & Clark 1982 \\
\hline Sitkalidak Roadcut & 49KOD438 & Ocean Bay I & Ocean Bay I & Clark 1982 \\
\hline Slate Site & 49AFO109 & - & Ocean Bay II & Clark 1982 \\
\hline $\begin{array}{l}\text { St. Mungo } \\
\text { Cannery }\end{array}$ & $\operatorname{DgRr}-2$ & - & - & Calvert 1970 \\
\hline T’ukw’aa & DfSi 23 & "Defensive" Site & West Coast (?) & $\begin{array}{l}\text { McMillan and St. Claire } \\
1992\end{array}$ \\
\hline T'ukw’aa & DfSi 23 & "Village" Site & West Coast (?) & $\begin{array}{l}\text { McMillan and St. Claire } \\
1992\end{array}$ \\
\hline Tanginak Spring & 49KOD481 & - & - & Fitzhugh 2004 \\
\hline \multirow[t]{2}{*}{ Tsawwassen } & DgRs 2 & Transitional & Transitional & $\begin{array}{l}\text { ARCAS Consulting } \\
1999\end{array}$ \\
\hline & DgRs 2 & Stselax & Stselax & ARCAS Consulting \\
\hline
\end{tabular}




\begin{tabular}{|c|c|c|c|c|}
\hline Site Name & Site Number & $\begin{array}{c}\text { Assemblage/ } \\
\text { Component }\end{array}$ & Phase & Source \\
\hline Tsawwassen & & & & 1999 \\
\hline Tsawwassen & DgRs 2 & Marpole & Marpole & $\begin{array}{l}\text { ARCAS Consulting } \\
1999\end{array}$ \\
\hline Tsawwassen & DgRs 2 & St. Mungo & St. Mungo & $\begin{array}{l}\text { ARCAS Consulting } \\
1999\end{array}$ \\
\hline Tsawwassen & DgRs 2 & Unknown & - & $\begin{array}{l}\text { ARCAS Consulting } \\
1999\end{array}$ \\
\hline Ts'ishaa & DfSi 16 & "Back Terrace" & $\begin{array}{l}\text { West } \\
\text { Coast/Locarno-like }\end{array}$ & $\begin{array}{l}\text { McMillan and St. Claire } \\
2005\end{array}$ \\
\hline Ts'ishaa & DfSi 16 & Area 1 & $\begin{array}{l}\text { West } \\
\text { Coast/Locarno-like }\end{array}$ & $\begin{array}{l}\text { McMillan and St. Claire } \\
2005\end{array}$ \\
\hline Ts'ishaa & DfSi 16 & Area 2 & $\begin{array}{l}\text { West } \\
\text { Coast/Locarno-like }\end{array}$ & $\begin{array}{l}\text { McMillan and St. Claire } \\
2005\end{array}$ \\
\hline Ts'ishaa & DfSi 16 & Area 3 & $\begin{array}{l}\text { West } \\
\text { Coast/Locarno-like }\end{array}$ & $\begin{array}{l}\text { McMillan and St. Claire } \\
2005\end{array}$ \\
\hline West Point & $45 \mathrm{KI} 428 / 9$ & Component I & 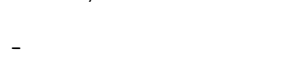 & $\begin{array}{l}\text { Larson and Lewarch } \\
1995\end{array}$ \\
\hline West Point & $45 \mathrm{KI} 428 / 9$ & Component II & - & $\begin{array}{l}\text { Larson and Lewarch } \\
1995\end{array}$ \\
\hline West Point & $45 \mathrm{KI} 428 / 9$ & Component III & - & $\begin{array}{l}\text { Larson and Lewarch } \\
1995\end{array}$ \\
\hline West Point & $45 \mathrm{KI} 428 / 9$ & Component IV & - & $\begin{array}{l}\text { Larson and Lewarch } \\
1995\end{array}$ \\
\hline Wet Creek & HiTp 1 & - & - & Fladmark 1985 \\
\hline Yuquot & DjSp 1 & Component II & - & $\begin{array}{l}\text { Folan and Dewhirst } \\
1980\end{array}$ \\
\hline Yuquot & DjSp 1 & Component III & - & $\begin{array}{l}\text { Folan and Dewhirst } \\
1980\end{array}$ \\
\hline
\end{tabular}




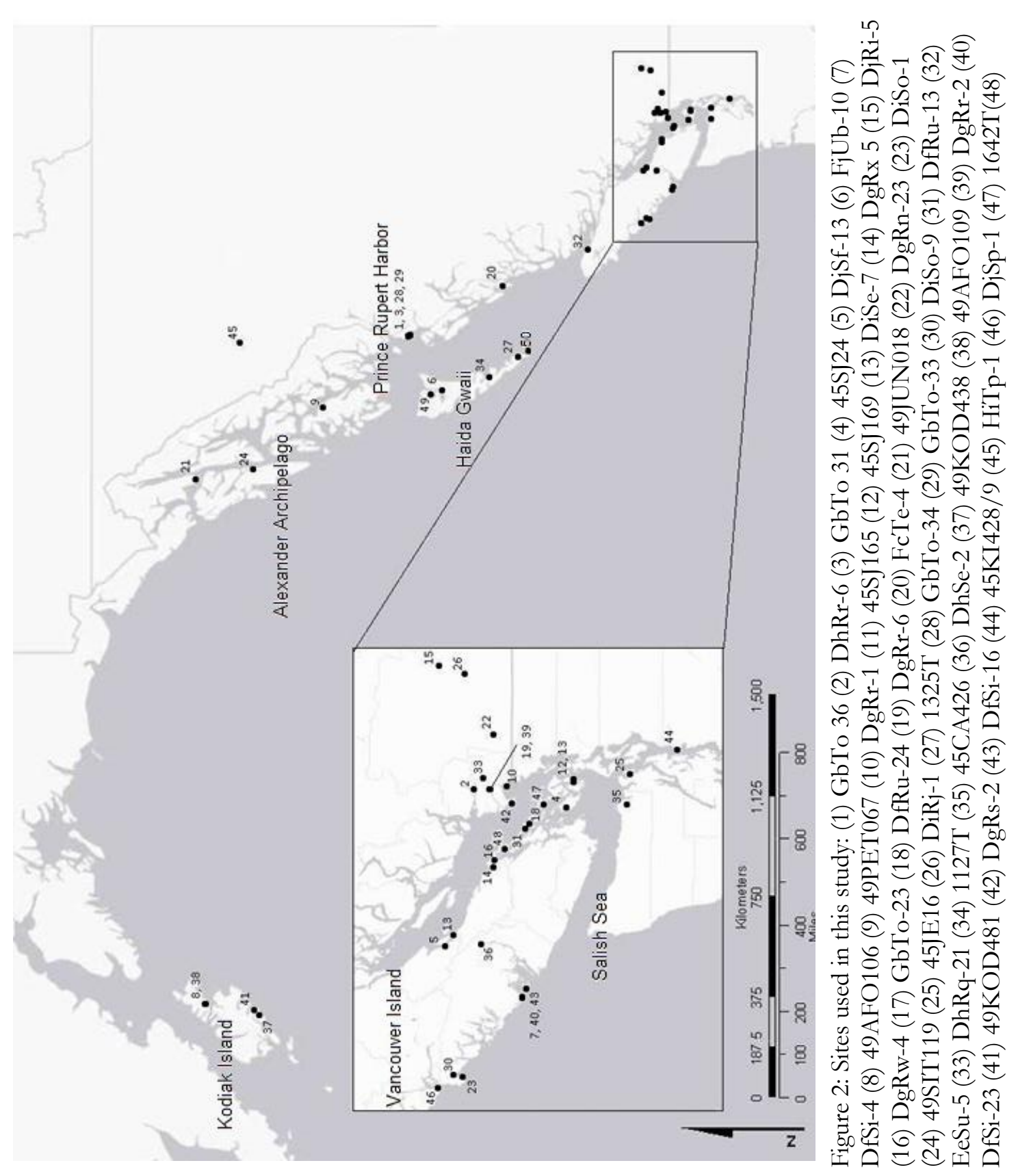




\subsection{Radiocarbon Calibration and Hygiene}

Associating the appearance of slate points with as specific a date as possible is the cornerstone of this thesis, and radiocarbon dating allows us to establish, within a margin of error, the date of an archaeological deposit. Radiocarbon dating is a method which allows for the dating of organic material (charcoal, most often) by counting how much of the isotope carbon $14\left({ }^{14} \mathrm{C}\right)$ remains in the sample. ${ }^{14} \mathrm{C}$ decays at a constant rate, and organisms stop absorbing it from the atmosphere (or ocean) once they perish. When selecting ${ }^{14} \mathrm{C}$ samples for my database, I took special note of any information which might help me better associate the samples with human activities more closely, such as samples from hearths, or bone (and more rarely wood) tools.

All dates used in this thesis are reported in calibrated form (i.e. converted to calendar years). The decision to calibrate all dates in the database was made in order to establish some degree of standardization for the variety of reporting practices found in the site reports. Some authors report dates uncalibrated, and those who did report calibrated dates may very likely have used different calibration curves (calibration curves are discussed in greater detail below). As timing is the key to this study, I felt that calibrating (or recalibrating) all dates using the same, recent calibration curve would help to minimize the variability introduced by collecting dates from so many different sources.

\subsubsection{Calibrating Radiocarbon Dates}

Radiocarbon dates are frequently reported uncalibrated, that is, not corrected for the variation over time in the levels of ${ }^{14} \mathrm{C}$ found in atmospheric or oceanic $\mathrm{CO}_{2}$. A number of radiocarbon calibration curves have been established to control for this variation. Calibration curves are constructed by measuring the radiocarbon age of tree rings of known or other 
independently dated samples, which allows us to convert radiocarbon years to calendar years (Stuiver et al. 2005a). I used the program CALIB 7.0, and the provided "IntCal13" curve for the Northern Hemisphere for most samples (Stuiver, et al. 2005b). For shell samples, an additional procedure was necessary. Marine (and lacustrine) organisms absorb their $\mathrm{CO}_{2}$ from the surrounding water, not from the atmosphere like terrestrial organisms. Aquatic sources of $\mathrm{CO}_{2}$ have a different isotopic carbon ratio $\left({ }^{13} \mathrm{C} /{ }^{14} \mathrm{C}\right)$ than the atmosphere, and unless this marine reservoir effect is accounted for, the calibration will produce an erroneous date (Stuiver, et al. 2005a). As such, I used the "Marine13" curve for where a marine correction was necessary, which corrects global variation in carbon 14. Shell samples could be corrected even further by inputting a $\Delta \mathrm{R}$ value, which corrects the global oceanic ${ }^{14} \mathrm{C}$ levels to a local value. Additionally, research by Deo et al. (2004) has indicated that $\Delta \mathrm{R}$ values vary not just geographically, but temporally (as does atmospheric ${ }^{14} \mathrm{C}$ ). In their study of ${ }^{13} \mathrm{C} /{ }^{14} \mathrm{C}$ fractions in the Puget Sound and Gulf of Georgia region, they found that while a $\Delta \mathrm{R}$ value of +400 years for the region was common from $0-500 \mathrm{BP}$, this value dropped to almost zero for dates spanning the period of 500-1,200 BP, and returned to around 400 years for 1,200-3,000 BP. There were eight shell dates in the database I have complied, four from the Boardwalk Site in Prince Rupert Harbor had $\Delta \mathrm{R}$ corrections supplied by the author of the Report (Ames 2005), and four from Vancouver Island's Duke Point site did not. Fortunately, there exists an online marine reservoir correction database maintained by Queen's University Belfast (http://calib.qub.ac.uk/marine), and a $\Delta \mathrm{R}$ value collected from an area $25 \mathrm{~km}$ from the Duke Point site was available (+440 years). Only one shell date from the Gulf of Georgia was employed in my analyses, which retuned a calibrated date of 3,1432,560 cal BP. This date puts the sample well outside the 500-1,200 BP anomaly identified by 
Deo et al. The $\Delta \mathrm{R}$ values used in this study, and their sources, are listed in Section 3.2, Table 4. Samples with mixed marine/terrestrial ${ }^{14} \mathrm{C}$ sources (e.g. bones from humans who eat significant amounts of marine protein) are still further complicated, as calibration requires an estimate of the percentage of marine carbon in the diet. Fortunately, of the 26 dates run on human bone used for this study, 25 had estimations of marine diet percentage supplied by the authors of the reports, and only one such date was selected for analysis in this work. The calibration software used in this study (CALIB 7.0) allows for the input of marine carbon estimates to further refine calibrated dates. For the results of the radiocarbon date calibrations undertaken for this study see section 3.2.

\subsubsection{Radiocarbon Hygiene}

The notion that an investigator must be cognizant of how closely their radiocarbon sample is associated with the phenomenon they wish to study is not a new one, on the contrary, it is over four decades old (Waterbolk 1971). This problem is of special importance to studies which make use of large radiocarbon datasets from diverse sources, such as this one, because the author's conclusions are only as strong as their least reliable data. Pettitt et al. (2003) have developed a method, building on the work of Spriggs (1983) and Springs and Anderson (1993), to address this issue. They identify two areas of concern when comparing radiometric dates from different sources: chronometric (confidence in the laboratory methods) and archaeological (confidence that the dated sample is relevant to the archaeological event(s) under study). They note that while it is generally accepted that some

${ }^{14} \mathrm{C}$ dates have greater archaeological validity than others, archaeologists are rarely fully explicit about their selection criteria for retaining or rejecting dates (Pettitt et al. 2003:1685). In an effort to codify this selection procedure, they have constructed a rubric for scoring the 
chronometric and archaeological validity of a sample; the idea being that the investigator's selection process for radiometric dates is "transparent," and strives for some degree of objectivity.

Many of Pettitt et al.'s criteria treat issues of unknown ${ }^{14} \mathrm{C} /{ }^{12} \mathrm{C}$ fractions (e.g. bone vs. charcoal samples) or accuracy beyond two ${ }^{14} \mathrm{C}$ half-lives. The latter is not directly applicable in this study (all the samples in this study are within a two ${ }^{14} \mathrm{C}$ half-life timeframe, and frequently one), and the former can largely be side-stepped by primarily using charcoal samples of terrestrial origin, or dates calibrated to account for the marine reservoir effect.

I established a simplified rubric (Table 2) for determining a confidence score for radiometric dates to be used in this study, using a 1-5 scoring of four criteria, based largely on Pettitt et al.'s work (2003:1690) but modified to work more effectively with the aggregated dataset used here. I frequently did not have access to the detailed information that their system requires, such as the likelihood of post-depositional contamination, or the size of the sample material. My four criteria can be grouped into two categories which address different areas of uncertainty. I have termed the first category "Chronometric" (Criteria I and II), which considers the possible difference between the date returned by the sample and the actual date of deposition (e.g. the old wood problem). Criterion I addresses the precision of the assay: was the date the result of a single sample of carbon, and not an aggregate ("bulked") sample of carbon? Criterion II addresses the source of sample, is the origin (i.e. marine, terrestrial) of the sample known and reported? Is the sample likely subject to the "old wood" problem? The next category is "Archaeological" (Criteria III and IV), which considers how closely the sample is related to the archaeological phenomena under study. Criterion III is concerned with certainty of association (i.e. can the dated sample be 
associated with human activity?). Criterion IV addresses the relevance of the dated sample (i.e. can the dated sample be associated with the specific archaeological event(s) in question?).

My initial plan, once each dated sample was scored, was to take samples which scored in the top $5 \%$ and $20 \%$ of dates to establish confidence intervals for the resulting timeframes. Samples that score below 50\% could be rejected as insufficiently reliable. A preliminary examination of the 484 dates for the 50 sites used here produced a few concerns, mostly in regards to criterion IV (relevance of dated sample, see Table 2). However, the majority of samples were charcoal, or in a few cases marine corrected bone or shell. There were less than 10 instances of charcoal samples being identified to plant genus, and the size of the sample is almost never reported. This did not allow me to make any account for "old wood" error. This is a greater problem at higher latitudes where timber is scarce, but it can be argued that driftwood is an attractive fuel source no matter how locally abundant live timber may be. The abundance of cedar (Thuja sp.) on the coast is also a cause for concern, as some trees can live for several hundred years. An interesting solution to the old wood problem has been employed by Friesen and Arnold (2008), who use radiocarbon dates run terrestrial mammal bone in their study of the Thule migration. Of the 484 dates collected for my database, only one was from a terrestrial mammal (bear). This date provided its own problems, as the marine content of a bear's diet is difficult to estimate, whereas the caribou bone employed by Friesen and Arnold was not subject to such ambiguity. The results of the radiocarbon hygiene program are reported in Section 3.1. 
Table 2: Scoring criteria for confidence in radiometric samples. Individual dates will be evaluated using these criteria, and the combined score (4-20) can then be recorded, allowing conclusions to be drawn from dates which fall into any percentage of confidence desired.

\begin{tabular}{|c|c|c|}
\hline \multirow[b]{2}{*}{ 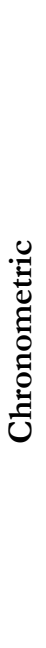 } & $\begin{array}{l}\text { I. Precision of sample- Was the date } \\
\text { the result of a single sample of } \\
\text { carbon, and not an aggregate } \\
\text { ("bulked") sample of carbon? }\end{array}$ & $\begin{array}{l}\text { 1. No confidence } \\
\text { 2. Little confidence } \\
\text { 3. Somewhat confident } \\
\text { 4. Confident } \\
\text { 5. Very confident }\end{array}$ \\
\hline & $\begin{array}{l}\text { II. Source of sample- Is the origin } \\
\text { (i.e. marine, terrestrial) of the sample } \\
\text { known and reported? Is the sample } \\
\text { likely subject to the "old wood" } \\
\text { problem? }\end{array}$ & $\begin{array}{l}\text { 1. The source of the sample is unknown } \\
\text { 2. The sample is marine in origin and uncorrected } \\
\text { 3. The sample is marine in origin, and has been } \\
\text { corrected globally, or the sample is terrestrial in origin, } \\
\text { but the "old wood" problem cannot be ruled out } \\
\text { 4. Or the sample is marine in origin and has been } \\
\text { locally corrected } \\
\text { 5. The sample is charcoal of terrestrial origin and for } \\
\text { which an "old wood" estimation can likely be ruled out } \\
\text { (i.e. small twigs, or samples identified to genus) }\end{array}$ \\
\hline \multirow[b]{2}{*}{ 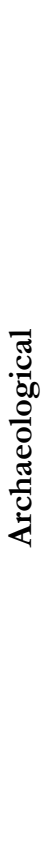 } & $\begin{array}{l}\text { III. Certainty of association- Can } \\
\text { the dated sample be associated with } \\
\text { human activity? }\end{array}$ & $\begin{array}{l}\text { 1. No confidence (e.g. sample was recovered from a } \\
\text { horizon with no evidence of human activity) } \\
\text { 2. Little confidence } \\
\text { 3. Somewhat confident } \\
\text { 4. Confident } \\
\text { 5. Very confident (e.g. dated sample is of human } \\
\text { manufacture) }\end{array}$ \\
\hline & $\begin{array}{l}\text { IV. Relevance of dated sample- } \\
\text { Can the dated sample be associated } \\
\text { with the specific archaeological } \\
\text { event(s) in question? }\end{array}$ & $\begin{array}{l}\text { 1. No confidence (e.g. no provenience data for dated } \\
\text { sample) } \\
\text { 2. Unlikely association (e.g. dated sample cannot be } \\
\text { attributed to any particular horizon or cultural layer) } \\
\text { 3. Likely association (e.g. sample is from a strata or } \\
\text { level associated with the culture in question) } \\
\text { 4. High probability of association (e.g. sample was } \\
\text { recovered from a feature, such as a hearth, that can be } \\
\text { demonstrably associated with the culture in question) } \\
\text { 5. Explicitly associated (e.g. the dated sample is either } \\
\text { culturally diagnostic itself, or it meets the criteria set out } \\
\text { in IV.4, as well as bearing traces of human manufacture } \\
\text { or modification }\end{array}$ \\
\hline
\end{tabular}

\subsection{Controlling for Inter-Site Variability}

There are a number of problems with making inter-site and inter-assemblage comparisons. Given the necessity of incorporating a wide array of data for this project (e.g. 
site reports not only from different authors and institutions, but different eras of archaeological practice); I have identified three major hurdles to data compatibility:

1. Comparability of radiometric data. As was noted above, this project requires compiling radiometric data from many investigators, some of which were collected as early as fifty years ago, with varying field and laboratory methodologies. This concern was addressed in Section 2.3.

2. Issues of reporting methods and standards. There are as many ways of reporting archaeological data as there are archaeologists, and each project has its own focus. There was no systematic way to deal with this issue; it was necessary to undertake the work of identifying and noting the idiosyncrasies of each investigator's methods, and to use the best data available on a case-by-case basis.

3. Issues of assemblage size, richness, and diversity. How many artifacts are necessary to provide an adequate sample to say something about the presence or absence of ground slate? Can one safely say that the people who occupied a given site did not use ground slate, when only 50 artifacts were recovered? Can one justify comparing data from a $4 \mathrm{~m}^{2}$ and $40 \mathrm{~m}^{2}$ excavations side by side?

This is not an uncommon question on the Northwest Coast, given the immense size of many sites in the region (e.g. shell middens). The problem has been addressed by Lyman (1991), in his study on the effects of excavation strategies on artifact richness and diversity. Lyman became concerned that perhaps site "type" attributions (sensu Binford 1980) based on artifact assemblages were more likely a function of how much of the site had been excavated, rather than reflecting actual, intrinsic properties of the site. To this end, he and his student Betz (1991) undertook a study to see if they could identify a correlation between 
number of artifacts recovered (richness), number of artifact classes recovered (diversity), and excavated volume and area. Betz's preliminary findings, based on her study of 21 sites on the Oregon coast, found a strong correlation between excavated area and number of individual artifacts recovered, with area possibly accounting for as much as $75 \%$ of the variability in an assemblage (Betz 1991:54). Excavated volume was only available for 12 of the 21 sites in her study, and possibly accounted for as much as 54\% of the artifact variability (Betz 1991:55). Betz postulated that this counterintuitive result arose from either greater assemblage variability in the upper, younger levels of archaeological sites or was simply due to the fact that there were considerably fewer sites with volume reported (Betz 1991).

Lyman took this work and built upon it, testing the regression formulae developed by Betz against 16 additional sites (Lyman 1991). In his study, Lyman actually found that Betz's equation for volume, not area, proved to be a better predictor of artifact richness and diversity. Using equations refined with his additional sites and artifact assemblages, Lyman concluded that to be reasonably assured that artifact diversity is adequately represented, $100 \mathrm{~m}^{3}$ of material must be excavated per 1,000 radiocarbon years spanned. He also concluded that $100 \mathrm{~m}^{3}$ at one site was "better" (i.e. provided a richer database) than ten $10 \mathrm{~m}^{3}$ excavations (Lyman 1991:313).

While Betz and Lyman were concerned primarily with attributing site types to assemblages, their work is useful for addressing my problem of assemblage completeness. Like Betz, I have excavated area figures for considerably more of my sites than I do excavated volume, and perhaps only ten which meet Lyman's cubic meters/per radiocarbon years threshold. Volume and area for my sites were recorded at the finest scale available from the site reports (rarely by component, more often on a site-wide basis). Often, 
excavated volume and area were not directly listed in the text of the reports, in these instances I made estimates based on plan view drawings on the excavations as well as profile drawings. However, these data do provide a useful metric for quantifying confidence in each assemblage used in this study relative to the others.

\subsection{Methods of Analysis}

The analyses employed in this thesis fall into two broad categories: analyses carried out for the purpose of evaluating inter-site comparability, and analyses aimed at establishing a spatiotemporal framework for the adoption of ground slate as well as the character of the chipped stone-ground slate point transition.

\subsubsection{Inter-Site Comparability Analyses}

As was mentioned in section 2.4, volume and area for my sites were recorded at the finest scale available from the site reports. It was necessary to estimate excavated volume for some sites; based on plan view drawings of the excavations as well as profile drawings. These data allowed me to evaluate how strongly excavated area and volume were influencing the number of ground slate points recovered for the sites used in this study. I performed a regression analysis (Pearson's r) using Microsoft Excel for both area and volume against number of ground slate points recovered to look for a correlation between these variables. The results of these analyses are reported in Section 3.4, Figures 4 and 5.

\subsubsection{Database Analyses}

A number of analyses were carried out using the database in an effort to identify patterns in the data. Microsoft Access and Excel were used to produce a table (Section 4.1, Table 7) which summarizes the changes in relative proportions (by component) of flaked stone points and ground slate points at each site. Excel was also employed to construct a 
series of floating bar charts, which allowed me to compare the earliest appearance of ground slate points at each site, and to sort and group the sites geographically and chronologically. The strongest pattern was evident when the sites are sorted by latitude, south to north, which gives a rough approximation (due to the complex geography of the Northwest Coast) of the order in which they would be encountered when moving down the coast. Radiocarbon dates for these figures were selected from the complete pool of calibrated dates using a general formula: the oldest date associated with ground slate points, and where applicable, the latest date preceding the appearance of ground slate, not associated with ground slate points, (to "bracket" the period of transition). This study is concerned specifically with the earliest appearance of ground slate points, not the longevity of the technology; and by selecting only the oldest positive date much of the "noise" is removed from the data. The earliest date without slate has been included to give some clue as to when the transition may have occurred, as well as illustrating how early that excavation reached. All dates used in these figures include a $2 \sigma$ error range. There are exceptions to this general pattern for selecting dates to plot. For example, several sites without a ground slate component have been included because this absence also carries information about the spread of the technology. This same procedure was repeated using only the top $50 \%$ scoring dates as a way to provide a higher level of confidence in the conclusions that can be drawn from the data, as well as to evaluate the effectiveness of my radiocarbon hygiene program. These data are reported in Section 3.6. In addition, I used ArcMap 10 to display regional details of this same information geographically by using classified (shaded) symbols overlaid on site locations. These results are presented in section 4.5 (Figures 13 and 14) as part of the discussion of individual sites. 


\section{Chapter 3: Results}

The analyses I present herein are aimed at answering the three research questions posed in Section 1.3, which to reiterate are: did slate points in fact replace functionally comparable chipped stone technologies? When did ground slate points first appear in the archaeological record of the Northwest Coast? And what geographic or temporal trends exist between the adoption of slate points and the decline of chipped stone technologies, either regionally or coast-wide?

Resolving the issue of the validity of inter-site comparisons is foundational to answering these questions, and as such I present 1 . The results of the radiocarbon hygiene program (section 3.1), 2. The results of my radiocarbon date calibrations (section 3.2), and 3 . The results of regression analyses which test for a correlation between excavation size and number of slate points recovered (sections 3.3 and 3.4), which are all aimed at demonstrating that the inter-site comparisons drawn in this thesis are robust and valid.

The final two sections in this chapter address my research questions directly. Section 3.5 presents the results of an analysis of the relative proportions of slate and chipped stone tools in the database I have assembled, in an effort to elucidate whether or not a chipped-toground transition is really evident. Section 3.6 presents a geographic and chronological sorting of my data, the product of which is a site-by-site chronological framework for the adoption of ground slate points, which addresses both the earliest appearance of ground slate points in the study area, and regional and temporal patterns evident therein. 


\section{1 $\quad{ }^{14} \mathrm{C}$ Hygiene Program Results}

Of the 484 dates used in this study, the mode score was 17, with a range of 4-19. See Figure 3. This narrow distribution meant that my original notion of using scores by $10 \%$ percentile group was not practical, so it was necessary instead to construct the chronology based on the top scoring $50 \%$ of dates (score of 17 or better). To evaluate the utility of the radiocarbon hygiene method, I have also constructed a chronology using the complete pool of dates to see if different conclusions can be drawn from this larger, but less reliable dataset.

With regards to the breakdown of scores by criteria at each site (Table 3), Criterion IV (association with specific archaeological events) was frequently the lowest scoring, with four dates scoring less than “3”, 193 dates scoring a “3”, 281 scoring a "4", and only six dates scoring a " 5 ". Most dates scored very well under Criteria II and III, which suggests that the investigators have an excellent familiarity with the problems associated with dating marine materials (criterion II), as well as excellent basic sample selection practices (criterion III). Criterion I did not prove to be the problem I had anticipated, even given that some of the dates used in this study are from the 1960's. There were no instances of investigators reporting unequivocally "bulked" dates, and only two dates where aggregate sampling was not explicitly reported, but possible (though unlikely) based on contextual clues from the report; both from the Georgeson Bay site (Haggarty and Sendey 1976). 


\section{${ }^{14} \mathrm{C}$ Hygiene Scores $(n=484)$}

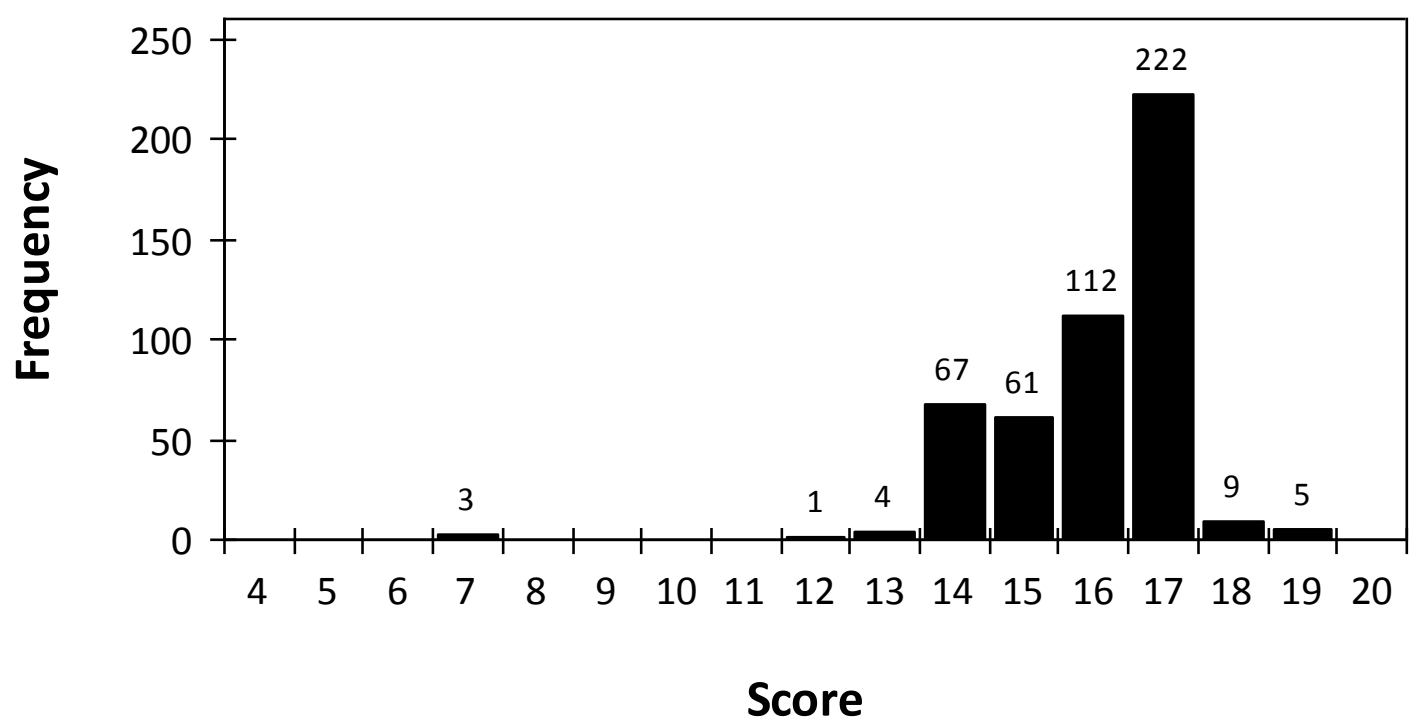

Figure 3: Frequency distribution of radiocarbon hygiene scores for $14 \mathrm{C}$ dates used in this study.

Table 3: Summary of scores by site; fractional mean scores represent instances when not all dates from a site received the same score (e.g. dates from hearths or tools). "Number of Dates" column reflects those likely to be associated with ground slate technology.

\begin{tabular}{|l|l|r|r|r|r|r|}
\hline \multirow{2}{*}{ Site Name } & Site Number & \multirow{2}{*}{$\begin{array}{c}\text { Number of } \\
\text { Dates }\end{array}$} & \multicolumn{5}{|c|}{ Mean Scores } \\
\cline { 4 - 8 } & & & I & II & III & IV \\
\hline Baldwin & GbTo-36 & 7 & 5 & 4 & 4 & 3 \\
Belcarra Park & DhRr-6 & 3 & 4 & 4 & 4 & 3 \\
Blue Jackets Creek & F1ua-4 & 2 & 5 & 4 & 4 & 4 \\
Boardwalk & GbTo-31 & 32 & 4.96 & 4 & 4 & 3.96 \\
British Camp & 45SJ24 & 14 & 5 & 4.36 & 4 & 4 \\
Buckley Bay & DjSf-13 & 1 & 5 & 2 & 4 & 4 \\
Cahoe Creek & FjUb-10 & 14 & 5 & 4 & 4 & 4 \\
Ch'uumat'a & DfSi-4 & 10 & 5 & 4 & 4 & 4 \\
Chert Site & 49AFO106 & 2 & 3 & 4 & 3 & 3 \\
Coffman Cove & 49PET067 & 3 & 4 & 4 & 4 & 4 \\
Crescent Beach & DgRr-1 & 11 & 5 & 4 & 4 & 3 \\
\hline
\end{tabular}




\begin{tabular}{|c|c|c|c|c|c|c|}
\hline Site Name & Site Number & Number of & \multicolumn{4}{|c|}{ Mean Scores } \\
\hline Decatur Island I & $45 \mathrm{SJ} 165$ & 2 & 5 & 4 & 3 & 3 \\
\hline Decatur Island II & $45 \mathrm{SJ} 169$ & 13 & 5 & 4 & 3 & 3 \\
\hline Deep Bay & DiSe-7 & 6 & 5 & 4 & 4 & 3.5 \\
\hline Dionisio Point & DgRv-3 & 2 & 5 & 4 & 4 & 4 \\
\hline Duke Point & DgRx -5 & 7 & 4.57 & 2.85 & 4 & 3 \\
\hline Esilao & DjRi-5 & 9 & 5 & 4 & 4 & 3.33 \\
\hline False Narrows & $\mathrm{DgRw}-4$ & 2 & 4.5 & 4 & 4.5 & 4 \\
\hline Garden Island & GbTo-23 & 12 & 5 & 3.16 & 4 & 4 \\
\hline Georgeson Bay & DfRu-24 & 2 & 2 & 1 & 3 & 1 \\
\hline Glenrose Cannery & DgRr-6 & 10 & 4 & 4 & 3 & 3 \\
\hline Grant Anchorage & FcTe-4 & 5 & 5 & 4 & 3.8 & 4.8 \\
\hline Ground Hog Bay 2 & 49JUN018 & 8 & 4 & 4 & 4 & 3 \\
\hline Hatzic Rock & DgRn-23 & 5 & 5 & 4 & 4 & 3.6 \\
\hline Hesquiat Village & DiSo-1 & 7 & 4 & 4 & 4 & 3 \\
\hline Hidden Falls & 49SIT119 & 27 & 4 & 4 & 4 & 3 \\
\hline Indian Island & 45JE16 & 4 & 4 & 4 & 4 & 4 \\
\hline Katz Site & DiRj-1 & 3 & 4 & 4 & 4 & 4 \\
\hline Kilgii Gwaay & $1325 \mathrm{~T}$ & 8 & 5 & 4 & 4.25 & 4.25 \\
\hline Kitandach & GbTo-34 & 5 & 5 & 4 & 4 & 4 \\
\hline Lachane & GbTo-33 & 22 & 5 & 4 & 4 & 4 \\
\hline Loon Cave & DiSo-9 & 7 & 4 & 3 & 3 & 3 \\
\hline Montague Harbour & DfRu-13 & 4 & 5 & 4 & 4 & 4 \\
\hline Narvaez Bay & $1642 \mathrm{~T}$ & 1 & 5 & 4 & 4 & 4 \\
\hline O'Connor & EeSu-5 & 3 & 5 & 4 & 4 & 4 \\
\hline Pitt River & DhRq-21 & 16 & 5 & 4.13 & 4.13 & 3.13 \\
\hline Richardson Island & $1127 \mathrm{~T}$ & 16 & 5 & 4 & 4 & 4 \\
\hline Sequim Bypass & 45CA426 & 19 & 5 & 4 & 4 & 4 \\
\hline Shoemaker Bay & DhSe-2 & 6 & 5 & 4 & 4 & 4 \\
\hline Sitkalidak Roadcut & 49KOD438 & 2 & 3 & 4 & 3 & 3 \\
\hline Slate Site & 49AFO109 & 4 & 3 & 4 & 4 & 3 \\
\hline St. Mungo Cannery & $\mathrm{DgRr}-2$ & 15 & 5 & 3.87 & 4.13 & 3.33 \\
\hline T’ukw'aa & DfSi-23 & 6 & 5 & 4 & 4 & 3.16 \\
\hline Tanginak Spring & 49KOD481 & 9 & 5 & 4 & 4 & 4 \\
\hline Tsawwassen & DgRs-2 & 15 & 5 & 3.06 & 4.53 & 4 \\
\hline Ts'ishaa & DfSi-16 & 27 & 5 & 4 & 4 & 4 \\
\hline West Point & $45 \mathrm{KI} 428 / 9$ & 52 & 5 & 4 & 4 & 3.33 \\
\hline Wet Creek & HiTp-1 & 1 & 5 & 4 & 4 & 4 \\
\hline Yuquot & DjSp-1 & 23 & 5 & 1 & 4 & 4 \\
\hline Total & & 484 & - & - & - & - \\
\hline
\end{tabular}




\subsection{Radiocarbon Calibration Results}

Of my database of 484 radiocarbon dates, 69 were selected for analysis, using the criteria outlined in section 2.5.2 (Database Analysis), which, to reiterate are: the oldest date for each site associated with ground slate points, and where applicable, the latest date preceding the appearance of ground slate, not associated with ground slate points.

Additionally, several sites without a ground slate component have been included in this analysis because this absence also carries information about the spread of the technology. In the event that multiple dates fit these criteria, the date with the highest radiocarbon hygiene score was used. Calibration outputs for CALIB 7.0 are expressed as a set of date ranges, and an attached probability that the date of the sample falls within those ranges. Calibrations for these 69 dates are presented below, summarized in Table 4. Figures 10-12, 15-17 (presented in the regional discussion of sites, Section 4.4) represent the probability distribution of these calibrations. 


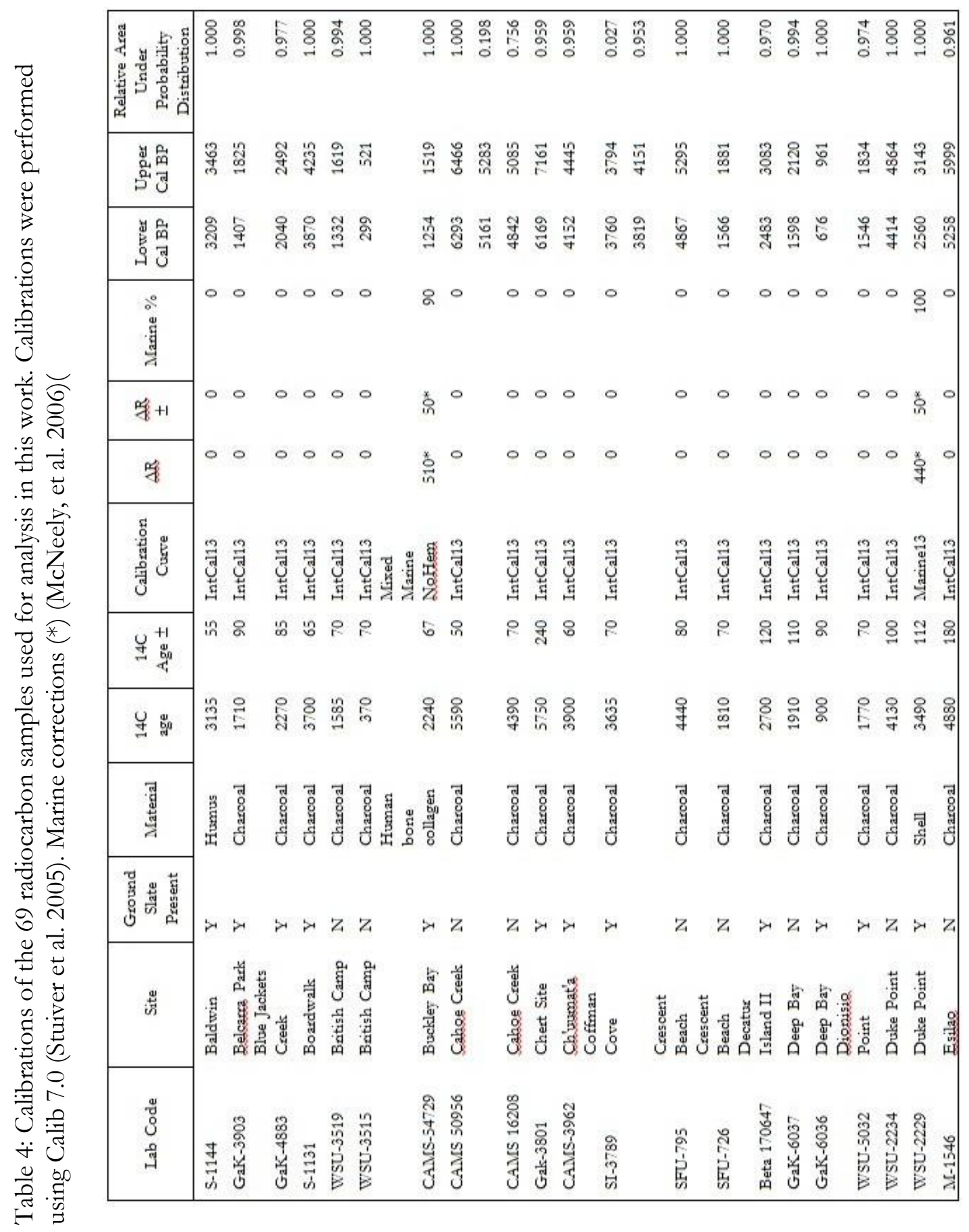




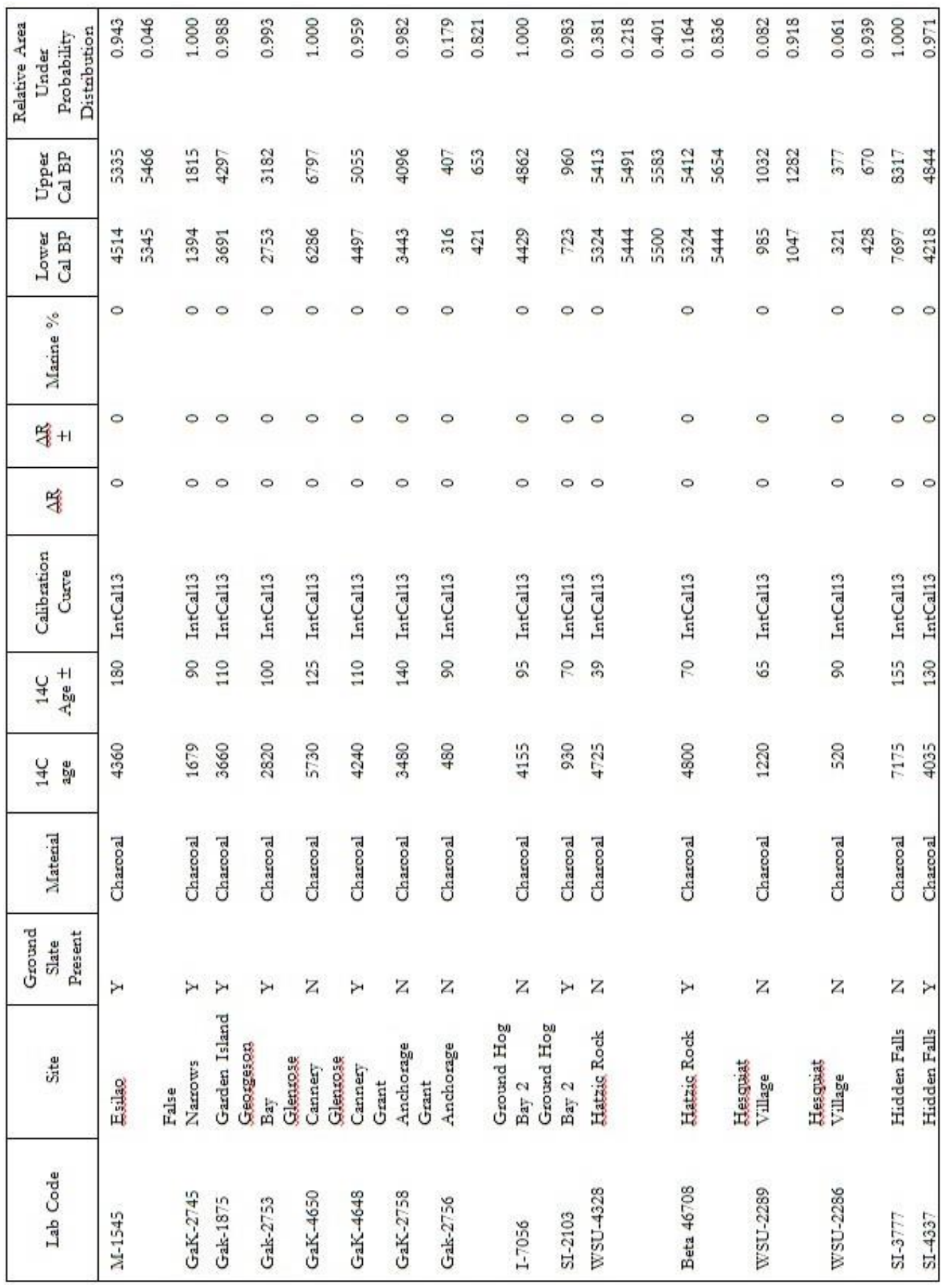




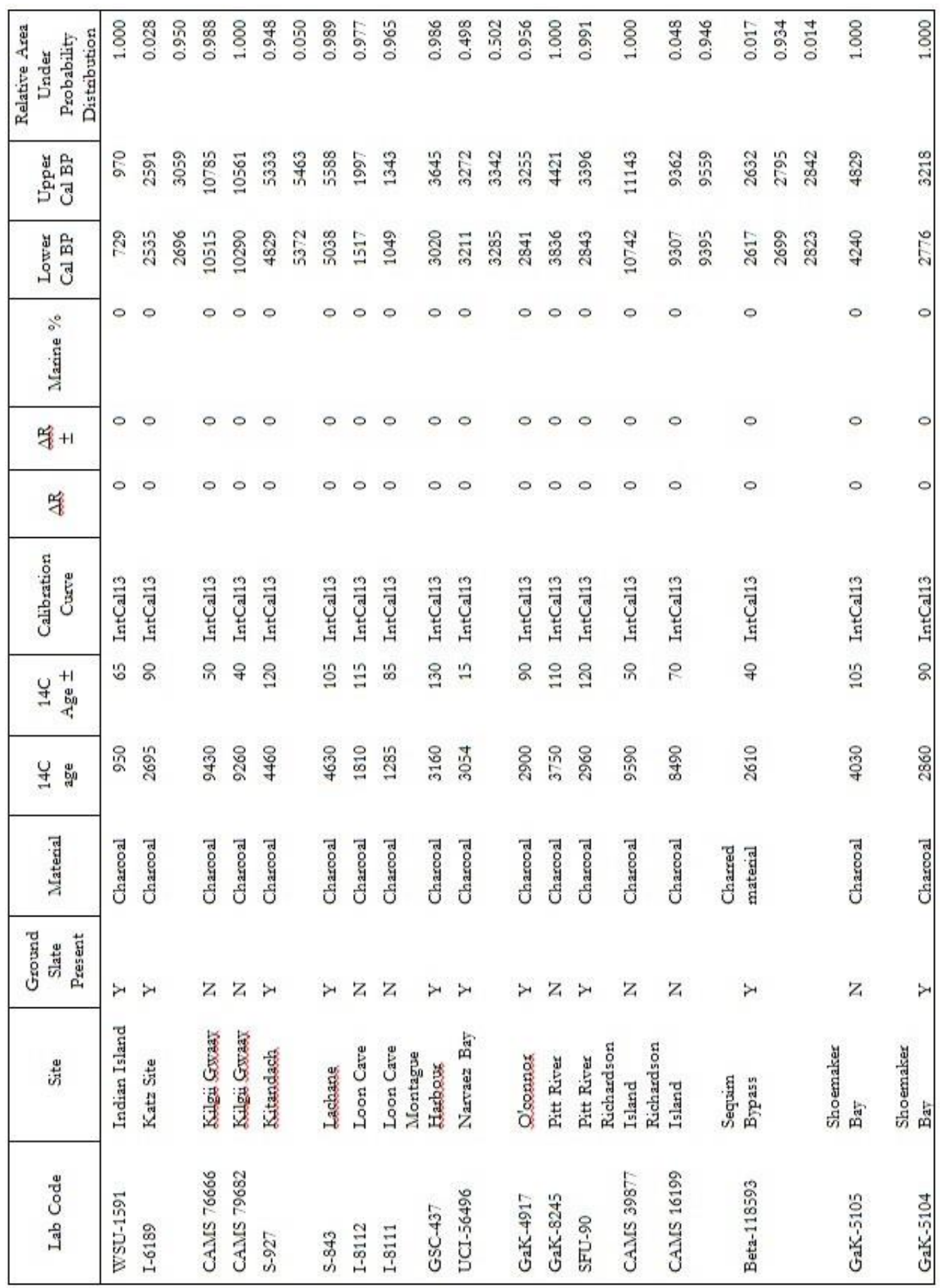




\begin{tabular}{|c|c|c|c|c|c|c|c|c|c|c|c|c|c|c|}
\hline 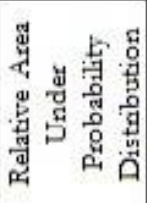 & $\begin{array}{l}\overrightarrow{0} \\
\stackrel{0}{0} \\
0\end{array}$ & ஃ̊ & 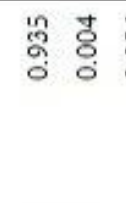 & 융 & 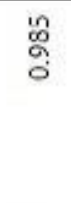 & $\underset{-}{8}$ & in & 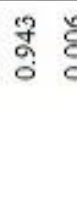 & 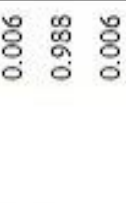 & 88 & $\begin{array}{ll}0 & 5 \\
0 & \delta \\
0 & \delta \\
0 & 0\end{array}$ & \% & & \\
\hline 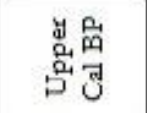 & 哭 & 옴 & 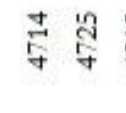 & 管 & 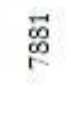 & ్ֻสู & ชู & 亗 & 哭总青 & 䓌 & 害 壳 & 喜 & & 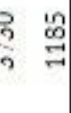 \\
\hline 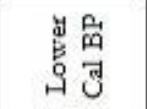 & 5 & 品 & 等穿 & हn & $\overrightarrow{8}$ & 8 & 呑 & \begin{tabular}{ll}
$\infty$ \\
\multirow{2}{7}{} \\
7
\end{tabular} & 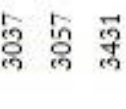 & సี & 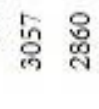 & है & & $\begin{array}{ll}0 \\
0 \\
0 & 0 \\
2 & 0 \\
0\end{array}$ \\
\hline 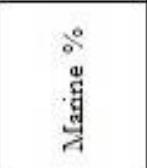 & 0 & 0 & 0 & & $\circ$ & 0 & 0 & $c$ & 0 & $\circ 0$ & $\circ 0$ & 0 & o & 0 \\
\hline$\frac{q}{8}+1$ & $\circ$ & 0 & 0 & & 0 & 0 & 0 & & 0 & $\circ 0$ & $\circ 0$ & 0 & $\circ$ & 0 \\
\hline q & 0 & 0 & 0 & & 0 & 0 & 0 & & 0 & $\circ 0$ & $\circ 0$ & 0 & 0 & 0 \\
\hline 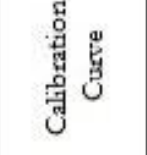 & 录 & 夛 & 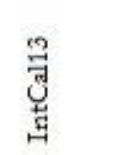 & & 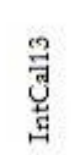 & 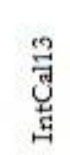 & 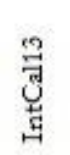 & & 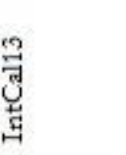 & 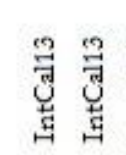 & 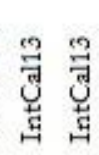 & 窇 & & 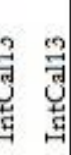 \\
\hline 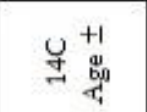 & 2 & 육 & 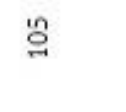 & & 옥 & 8 & 8 & & 웅 & 응 8 & 오용 & 8 & \& & 3. 욤 \\
\hline 导嵒 & ㅇํํ & 喿 & 응 & & 8 & $\begin{array}{l}P \\
\text { !n } \\
\text { nิ }\end{array}$ & 员 & & 요 & 융 윰 & 응 융 & 员 & & ถู \\
\hline $\begin{array}{l}\text { 㚜 } \\
\text { 永 }\end{array}$ & $\begin{array}{l}\text { 졍 } \\
\text { gु } \\
\text { dु }\end{array}$ & $\begin{array}{l}\text { 져 } \\
\text { ठ․ } \\
\text { gु }\end{array}$ & $\begin{array}{l}\text { ]ี } \\
\text { gु } \\
\text { gु }\end{array}$ & & $\begin{array}{l}\text { गु } \\
\text { gु } \\
\text { gु }\end{array}$ & $\begin{array}{l}\text { 경 } \\
\text { 영 }\end{array}$ & $\begin{array}{l}\text { 경 } \\
\text { 영 } \\
\text { తु }\end{array}$ & & $\begin{array}{l}\text { बु } \\
\text { gु } \\
\text { gु }\end{array}$ & 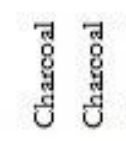 & 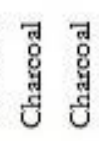 & 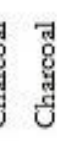 & & 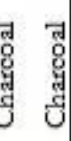 \\
\hline 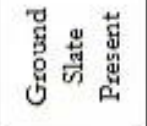 & $-\gamma$ & & $i-1$ & & Z & 乙 & $i$ & & Z & 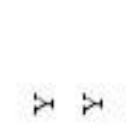 & $\mathrm{zi}$ & -7 & 47 & Z \\
\hline 节 & 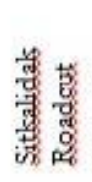 & 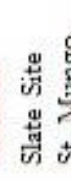 & 势 & & 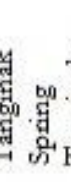 & 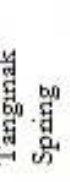 & 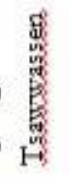 & & 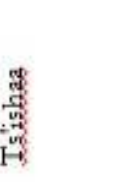 & 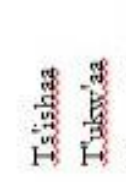 & 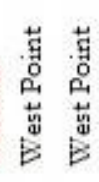 & 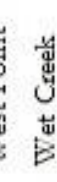 & & 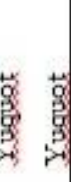 \\
\hline $\begin{array}{l}\text { वृँ } \\
8 \\
\text { बूँ }\end{array}$ & $\begin{array}{l}\frac{9}{8} \\
\text { 总 } \\
\stackrel{1}{1}\end{array}$ & $\underset{\frac{a}{\dot{1}}}{n}$ & 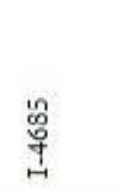 & & 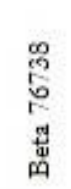 & 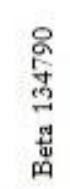 & 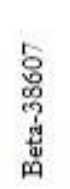 & & 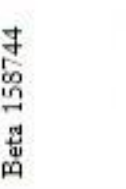 & 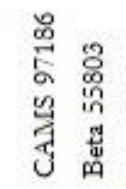 & 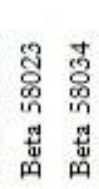 & 豈 & & 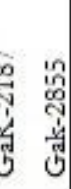 \\
\hline
\end{tabular}




\subsection{Excavated Volume Figures and Estimates}

As was discussed in section 2.4 (Controlling for Inter-Site Variability), it was necessary for this study to take into consideration the effect of variable excavation sizes when comparing artifact assemblages between sites. Table 5 lists excavated area and volume, when reported, for the sites used in this study. This data was then used for regression analyses (section 3.4).

Table 5: Excavated area and volume by site.

\begin{tabular}{|c|c|c|c|}
\hline Site & Site Number & $\begin{array}{l}\text { Excavated Area } \\
\left(\mathrm{m}^{2}\right)\end{array}$ & Excavated Volume $\left(\mathrm{m}^{3}\right)$ \\
\hline Baldwin & GbTo-36 & - & 208 \\
\hline Blue Jackets Creek & F1ua-4 & 24 & $67.2^{*}$ \\
\hline Belcarra Park & DhRr-6 & 60 & 180 \\
\hline Boardwalk & GbTo-31 & - & 1032 \\
\hline British Camp & $45 \mathrm{SJ} 24$ & 24 & - \\
\hline Buckley Bay & DjSf-13 & 36 & - \\
\hline Cahoe Creek & FjUb-10 & 10 & - \\
\hline Chert Site & 49AFO106 & - & - \\
\hline Ch'uumat'a & DfSi-4 & - & 56.4 \\
\hline Coffman Cove & 49PET067 & 7 & - \\
\hline Crescent Beach & DgRr-1 & 58 & 18.8 \\
\hline Decatur Island I/II & $45 \mathrm{SJ} 165 / 9$ & - & - \\
\hline Deep Bay & DiSe-7 & 20 & $60 *$ \\
\hline Dionisio Point & $\mathrm{DgR}_{\mathrm{v}}-3$ & 77 & - \\
\hline Duke Point & $\operatorname{DgRx}-5$ & 92 & - \\
\hline Esilao & DjRi-5 & $120^{*}$ & $500^{*}$ \\
\hline False Narrows & $\mathrm{DgRw}-4$ & 132 & - \\
\hline Garden Island & GbTo-23 & - & 297 \\
\hline Georgeson Bay & DfR- 24 & - & - \\
\hline Glenrose Cannery & DgRr-6 & - & - \\
\hline Grant Anchorage & Fc'Te-4 & 54 & - \\
\hline Ground Hog Bay 2 & 49JUN018 & $12^{*}$ & - \\
\hline Hatzic Rock & DgRn-23 & $92 *$ & - \\
\hline Hesquiat Village & DiSo-1 & 32 & - \\
\hline Hidden Falls & 49SIT119 & - & - \\
\hline Indian Island & 45JE16 & - & - \\
\hline
\end{tabular}




\begin{tabular}{|c|c|c|c|}
\hline Site & Site Number & $\begin{array}{c}\text { Excavated Area } \\
\qquad\left(\mathrm{m}^{2}\right)\end{array}$ & Excavated Volume $\left(\mathrm{m}^{3}\right)$ \\
\hline Katz Site & DiRj-1 & - & - \\
\hline Kilgii Gwaay & $1325 \mathrm{~T}$ & - & 16 \\
\hline Kitandach & GbTo-34 & - & 1655 \\
\hline Lachane & GbTo-33 & & 1000 \\
\hline Loon Cave & DiSo-9 & $24^{*}$ & - \\
\hline Montague Harbour & DfRu-13 & 74.31 & 156.02 \\
\hline Narvaez Bay & $1642 \mathrm{~T}$ & - & - \\
\hline O'Connor & EeSu-5 & 50 & - \\
\hline Pitt River & DhRq-21 & $113^{\dagger}$ & $42^{\dagger}$ \\
\hline Richardson Island & $1127 \mathrm{~T}$ & 2.5 & $12.5^{*}$ \\
\hline Sequim Bypass & 45CA426 & - & 121.7 \\
\hline Shoemaker Bay & DhSe-2 & $180^{*}$ & - \\
\hline Sitkalidak Roadcut & 49KOD438 & - & - \\
\hline Slate Site & 49AFO109 & - & - \\
\hline St. Mungo Cannery & DgRr-2 & - & - \\
\hline Tanginak Spring & 49KOD481 & - & - \\
\hline Tsawwassen & DgRs-2 & - & - \\
\hline Ts'ishaa & DfSi-16 & - & 207.7 \\
\hline T'ukw'aa & DfSi-23 & - & 150.9 \\
\hline West Point & $45 \mathrm{KI} 428 / 9$ & - & - \\
\hline Yuquot & DjSp-1 & - & - \\
\hline
\end{tabular}

* Figure Estimated by J. Dinwiddie.

† Incomplete total- excavated area and volume were only reported for some components. 


\subsection{Regression Analysis Results}

Regression analyses were performed using Microsoft Excel in order to test for the degree of correlation between excavated area (Figure 4) and volume (Figure 5) with the number of ground slate points recovered.

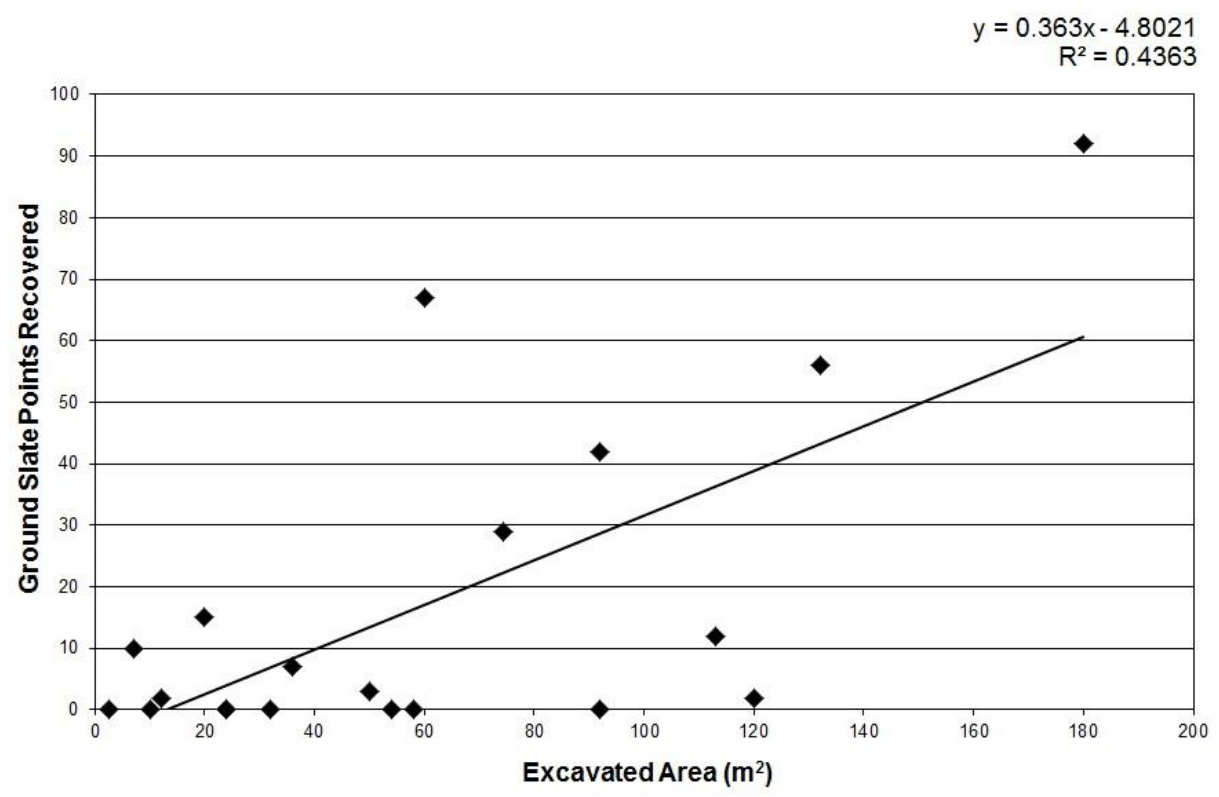

Figure 4: Regression analysis for area and ground slate points recovered $(\mathrm{n}=20)$

With regards to Figure 4, There is a strong positive correlation $(r=0.66)$ between the excavated area and number of ground slate points recovered, and this finding is significant at a 95\% confidence interval $(p=0.001)$. However, the $R^{2}$ statistic $(0.436)$ would suggest that although there is a correlation, area is a poor predictor for the number of ground slate points recovered. From this I gather that while increasing the area of an excavation should yield more ground slate points, this is not the sole factor with regards to the number of points recovered. 


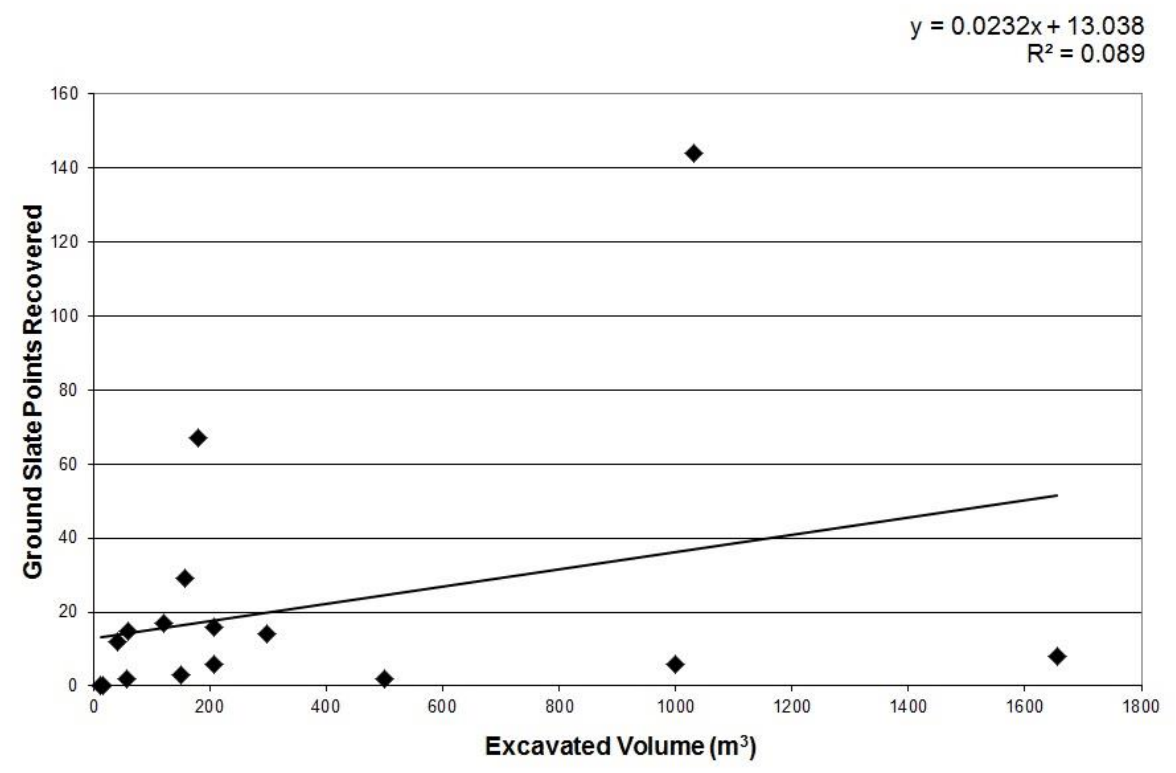

Figure 5: Regression analysis for volume and ground slate points recovered $(n=16)$.

With regards to Figure 5, There is a weak positive correlation $(r=0.30)$ between the excavated volume and number of ground slate points recovered, however, this finding is not significant at a $95 \%$ confidence interval $(\mathrm{p}=0.261)$. The $\mathrm{R}^{2}$ statistic $(0.089)$ would suggest that excavated volume is an extremely poor predictor for the number of ground slate points recovered, but given that correlation has not been unequivocally demonstrated, this result is unsurprising. This test proved to be largely inconclusive, excavation size just does not seem to be affecting the number of slate points recovered from these sites. While further analysis of this data (particularly in regards to outliers) would be interesting, such work is outside the scope of this thesis. 


\subsection{Database Analysis Results}

In an effort to address whether or not the "Ground Slate Transition" is in fact a transition per se, I have compiled the following table which compares the relative proportions of ground slate point and chipped stone points recovered from the study sites. These proportions are compared across components, rather than fixed date ranges, (as would be preferable) due to inconsistent reporting of depth for recovered artifacts. The drawback to this is that these proportion comparisons are valid only within a site, not across sites (unless, as was sometimes the case, components were attributed to a phase, e.g. "Marpole").

Table 6: Presence or absence of ground slate points by site and component. (*) Indicates a site component that is a horizontal (different area of the site) distinction rather than a vertical (chronological) distinction. Where applicable, components are sorted youngest (top) to oldest (bottom).

\begin{tabular}{|c|c|c|c|c|c|}
\hline Site Name & $\begin{array}{c}\text { Site } \\
\text { Number }\end{array}$ & $\begin{array}{c}\text { Assemblage/ } \\
\text { Component }\end{array}$ & $\begin{array}{c}\text { Slate } \\
\text { Points }\end{array}$ & $\begin{array}{l}\text { Flaked } \\
\text { Points }\end{array}$ & $\begin{array}{c}\% \text { Slate } \\
\text { Points of } \\
\text { Total } \\
\text { Points }\end{array}$ \\
\hline Baldwin & GbTo 36 & - & 16 & 0 & 1.00 \\
\hline Belcarra Park & $\operatorname{DhRr} 6$ & Components I-II & 65 & 162 & 0.34 \\
\hline $\begin{array}{l}\text { Blue Jackets } \\
\text { Creek }\end{array}$ & F1ua-4 & 1 & + & + & No data \\
\hline \multirow[t]{5}{*}{ Boardwalk } & GbTo 31 & $\mathrm{AU} / \mathrm{S}^{*}$ & 50 & 0 & 1.00 \\
\hline & & AU 1 & 17 & 0 & 1.00 \\
\hline & & AU 2 & 30 & 0 & 1.00 \\
\hline & & AU 3 & 10 & 0 & 1.00 \\
\hline & & AU 4 & 2 & 0 & 1.00 \\
\hline \multirow[t]{2}{*}{ British Camp } & $45 \mathrm{SJ} 24$ & Ethnozone I & 0 & 26 & 0.00 \\
\hline & & Ethnozone II & 0 & 7 & 0.00 \\
\hline Buckley Bay & DjSf-13 & - & 7 & 0 & 1.00 \\
\hline \multirow[t]{2}{*}{ Cahoe Creek } & FjUb 10 & Components I-III & 0 & 0 & $\mathrm{n} / \mathrm{a}$ \\
\hline & & Component IV & 0 & 0 & $\mathrm{n} / \mathrm{a}$ \\
\hline Ch'uumat'a & DfSi 4 & $-\quad 1+2-2$ & 2 & 0 & 1.00 \\
\hline \multirow[t]{2}{*}{ Chert Site } & 49AFO106 & Ocean Bay II & 31 & 36 & 0.46 \\
\hline & & Ocean Bay I & 0 & 33 & 0.00 \\
\hline $\begin{array}{l}\text { Coffman } \\
\text { Cove }\end{array}$ & 49PET067 & 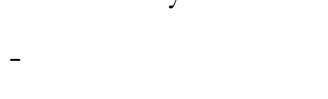 & 10 & 0 & 1.00 \\
\hline $\begin{array}{l}\text { Crescent } \\
\text { Beach }\end{array}$ & DgRr1 & - & 0 & 9 & 0.00 \\
\hline
\end{tabular}




\begin{tabular}{|c|c|c|c|c|c|}
\hline Site Name & $\begin{array}{c}\text { Site } \\
\text { Number }\end{array}$ & $\begin{array}{c}\text { Assemblage/ } \\
\text { Component }\end{array}$ & $\begin{array}{c}\text { Slate } \\
\text { Points }\end{array}$ & $\begin{array}{l}\text { Flaked } \\
\text { Points }\end{array}$ & $\begin{array}{c}\% \text { Slate } \\
\text { Points of } \\
\text { Total } \\
\text { Points }\end{array}$ \\
\hline \multirow{2}{*}{$\begin{array}{l}\text { Decatur } \\
\text { Island I }\end{array}$} & \multirow[t]{2}{*}{$45 \mathrm{SJ} 165$} & \multirow[t]{2}{*}{-} & & & \\
\hline & & & 0 & 1 & 0.00 \\
\hline \multirow{5}{*}{$\begin{array}{l}\text { Decatur } \\
\text { Island II }\end{array}$} & \multirow[t]{5}{*}{$45 \mathrm{SJ} 169$} & Component I & 0 & 1 & 0.00 \\
\hline & & Component II & 1 & 0 & 1.00 \\
\hline & & Component III & 1 & 1 & 0.50 \\
\hline & & Component IV & 0 & 0 & $\mathrm{n} / \mathrm{a}$ \\
\hline & & Component V & 1 & 1 & 0.50 \\
\hline \multirow[t]{3}{*}{ Deep Bay } & \multirow[t]{3}{*}{ DiSe-7 } & Component III & 3 & 0 & 1.00 \\
\hline & & Component II & 11 & 6 & 0.65 \\
\hline & & Component I & 1 & 16 & 0.06 \\
\hline \multirow{4}{*}{$\begin{array}{l}\text { Dionisio } \\
\text { Point } \\
\text { Duke Point }\end{array}$} & $\mathrm{DgRv}-3$ & - & + & + & No data \\
\hline & \multirow[t]{3}{*}{$\operatorname{DgRx} 5$} & Component III & 38 & 15 & 0.60 \\
\hline & & Component II & 3 & 12 & 0.20 \\
\hline & & Component I & 1 & 7 & 0.12 \\
\hline \multirow[t]{2}{*}{ Esilao } & \multirow[t]{2}{*}{ DjRi-5 } & Upper & 2 & 80 & 0.02 \\
\hline & & Lower & 0 & 33 & 0.00 \\
\hline \multirow{4}{*}{$\begin{array}{l}\text { False } \\
\text { Narrows } \\
\text { Garden } \\
\text { Island }\end{array}$} & DgRw 4 & Components III-IV & 56 & 75 & 0.43 \\
\hline & \multirow[t]{3}{*}{ GbTo 23} & AU 1 & 13 & 0 & 1.00 \\
\hline & & AU 2 & 1 & 0 & 1.00 \\
\hline & & AU Unknown & 0 & 0 & $\mathrm{n} / \mathrm{a}$ \\
\hline Georgeson & \multirow[t]{2}{*}{ DfRu 24} & Component II & 8 & 13 & 0.38 \\
\hline Bay & & Component I & 16 & 6 & 0.73 \\
\hline Glenrose & \multirow[t]{3}{*}{$\operatorname{Dg} \operatorname{Rr} 6$} & Marpole & 11 & 15 & 0.42 \\
\hline \multirow[t]{2}{*}{ Cannery } & & St. Mungo & 3 & 20 & 0.13 \\
\hline & & Old Cordilleran & 0 & 5 & 0.00 \\
\hline $\begin{array}{l}\text { Grant } \\
\text { Anchorage }\end{array}$ & FcTe-4 & 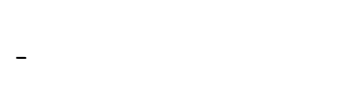 & 0 & 4 & 0.00 \\
\hline Ground Hog & \multirow[t]{2}{*}{ 49JUN018 } & Component I & 2 & 0 & 1.00 \\
\hline Bay 2 & & Component II & 0 & 0 & $\mathrm{n} / \mathrm{a}$ \\
\hline Hatzic Rock & DgRn-23 & Components I-III & $5^{\ddagger}$ & 42 & 0.10 \\
\hline \multirow{4}{*}{$\begin{array}{l}\text { Hesquiat } \\
\text { Village } \\
\text { Hidden Falls }\end{array}$} & DiSo 1 & 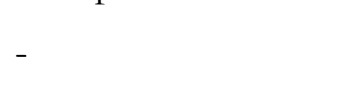 & 0 & 1 & 0.00 \\
\hline & \multirow[t]{3}{*}{ 49SIT119 } & Component III & 19 & 0 & 1.00 \\
\hline & & Component II & 80 & 0 & 1.00 \\
\hline & & Component I & 0 & 0 & $\mathrm{n} / \mathrm{a}$ \\
\hline Indian Island & 45JE16 & $-\quad 1$ & 0 & 1 & 0.00 \\
\hline Katz Site & DiRj 1 & Zone A* & 16 & 57 & 0.22 \\
\hline
\end{tabular}




\begin{tabular}{|c|c|c|c|c|c|}
\hline Site Name & $\begin{array}{c}\text { Site } \\
\text { Number }\end{array}$ & $\begin{array}{c}\text { Assemblage/ } \\
\text { Component }\end{array}$ & $\begin{array}{l}\text { Slate } \\
\text { Points }\end{array}$ & $\begin{array}{l}\text { Flaked } \\
\text { Points }\end{array}$ & $\begin{array}{c}\% \text { Slate } \\
\text { Points of } \\
\text { Total } \\
\text { Points }\end{array}$ \\
\hline & & Zone B* & 1 & 14 & 0.07 \\
\hline Kilgii Gwaay & $1325 \mathrm{~T}$ & Fedje et al. 2005 & 0 & 1 & 0.00 \\
\hline Kitandach & GbTo 34 & - & 8 & 0 & 1.00 \\
\hline Lachane & GbTo 33 & - & 6 & 0 & 1.00 \\
\hline Loon Cave & DiSo 9 & Component I/II & 0 & 0 & $\mathrm{n} / \mathrm{a}$ \\
\hline Montague & DfRu 13 & Component III & 18 & 11 & 0.62 \\
\hline Harbour & & Component I & 11 & 15 & 0.42 \\
\hline Narvaez Bay & $1642 \mathrm{~T}$ & - & + & $?$ & No data \\
\hline O'Connor & EeSu 5 & Components I-III & 3 & 0 & 1.00 \\
\hline \multirow[t]{5}{*}{ Pitt River } & DhRq-21 & Kroeker & 5 & 2 & 0.71 \\
\hline & & Mackenzie- Locarno & 2 & 0 & 1.00 \\
\hline & & Logodi- Locarno & 3 & 9 & 0.25 \\
\hline & & Mackenzie- Charles & 0 & 3 & 0.40 \\
\hline & & Logodi- Charles & 2 & 1 & 0.00 \\
\hline $\begin{array}{l}\text { Richardson } \\
\text { Island }\end{array}$ & $1127 \mathrm{~T}$ & - & 0 & 0 & $\mathrm{n} / \mathrm{a}$ \\
\hline $\begin{array}{l}\text { Sequim } \\
\text { Bypass }\end{array}$ & 45CA426 & Component II & 17 & 16 & 0.52 \\
\hline Shoemaker & DhSe-2 & Component II & 17 & 13 & 0.57 \\
\hline Bay & & Component I & 75 & 22 & 0.77 \\
\hline Sitkalidak & 49KOD438 & Ocean Bay II & 34 & 1 & 0.97 \\
\hline Roadcut & & Ocean Bay I & 6 & 10 & 0.38 \\
\hline Slate Site & 49AFO109 & - & 145 & 13 & 0.92 \\
\hline $\begin{array}{l}\text { St. Mungo } \\
\text { Cannery }\end{array}$ & DgRr-2 & - & + & + & $\mathrm{n} / \mathrm{a}^{\dagger}$ \\
\hline T'ukw'aa & DfSi 23 & $\begin{array}{l}\text { "Defensive" Site* } \\
\text { "Village" Site* }\end{array}$ & $\begin{array}{l}0 \\
3\end{array}$ & $\begin{array}{l}0 \\
0\end{array}$ & $\begin{array}{l}\mathrm{n} / \mathrm{a} \\
1.00\end{array}$ \\
\hline $\begin{array}{l}\text { Tanginak } \\
\text { Spring }\end{array}$ & 49KOD481 & - & 0 & 154 & 0.00 \\
\hline \multirow[t]{5}{*}{ Tsawwassen } & DgRs 2 & Stselax & 0 & 1 & 0.00 \\
\hline & & Transitional & 0 & 10 & 0.00 \\
\hline & & Marpole & 5 & 3 & 0.63 \\
\hline & & St. Mungo & 2 & 2 & 0.50 \\
\hline & & Unknown & 4 & 5 & 0.44 \\
\hline \multirow[t]{4}{*}{ Ts'ishaa } & DfSi 16 & "Back Terrace"* & 4 & 0 & 1.00 \\
\hline & & Area $1 *$ & 0 & 0 & $\mathrm{n} / \mathrm{a}$ \\
\hline & & Area $2 *$ & 0 & 0 & $\mathrm{n} / \mathrm{a}$ \\
\hline & & Area 3* & 2 & 0 & 1.00 \\
\hline \multirow[t]{3}{*}{ West Point } & 45KI428/9 & Component IV & 0 & 0 & $\mathrm{n} / \mathrm{a}$ \\
\hline & & Component III & 0 & 4 & 0.00 \\
\hline & & Component II & 1 & 12 & 0.08 \\
\hline
\end{tabular}




\begin{tabular}{|l|l|l|l|l|l|}
\hline Site Name & $\begin{array}{c}\text { Site } \\
\text { Number }\end{array}$ & $\begin{array}{c}\text { Assemblage/ } \\
\text { Component }\end{array}$ & $\begin{array}{c}\text { Slate } \\
\text { Points }\end{array}$ & $\begin{array}{c}\text { Flaked } \\
\text { Points }\end{array}$ & $\begin{array}{c}\text { Slate } \\
\text { Points of } \\
\text { Total } \\
\text { Points }\end{array}$ \\
\hline Wet Creek & HiTp 1 & Component I & 0 & 11 & 0.00 \\
Yuquot & DjSp 1 & Component III & 0 & 0 & $\mathrm{n} / \mathrm{a}$ \\
& & Component II & 0 & 0 & $\mathrm{n} / \mathrm{a}$ \\
\hline
\end{tabular}

tPoint counts for St. Mungo Cannery (DgRr-2) were not available, only presence/absence. ${ }^{\ddagger}$ The ground slate tools from Hatzic Rock (DgRn-23) are functionally ambiguous. They appear lanceolate in form; however, the investigator feels that they were likely knives. See The Fraser River and Fraser Delta in section 4.5.2.

\subsection{A Comparison of the Earliest Ground Slate Point Dates and Geography}

The figures below are a series of floating bar charts depicting the calibrated two sigma ranges of the 69 selected dates for each study site, with the sites arraigned north to south along the $\mathrm{Y}$ axis. The bars representing the dates have their probability distribution cures omitted for clarity. Figure 6 represents all of the selected 69 dates and all of the study sites. Figure 7 has sites with no ground slate component omitted. Figure 8 is constructed using dates selected (using the same criteria) from a pool limited to dates which scored in the top $50 \%$ of the radiocarbon hygiene process, the point being to evaluate whether or not the radiocarbon hygiene process produced a different trend. 

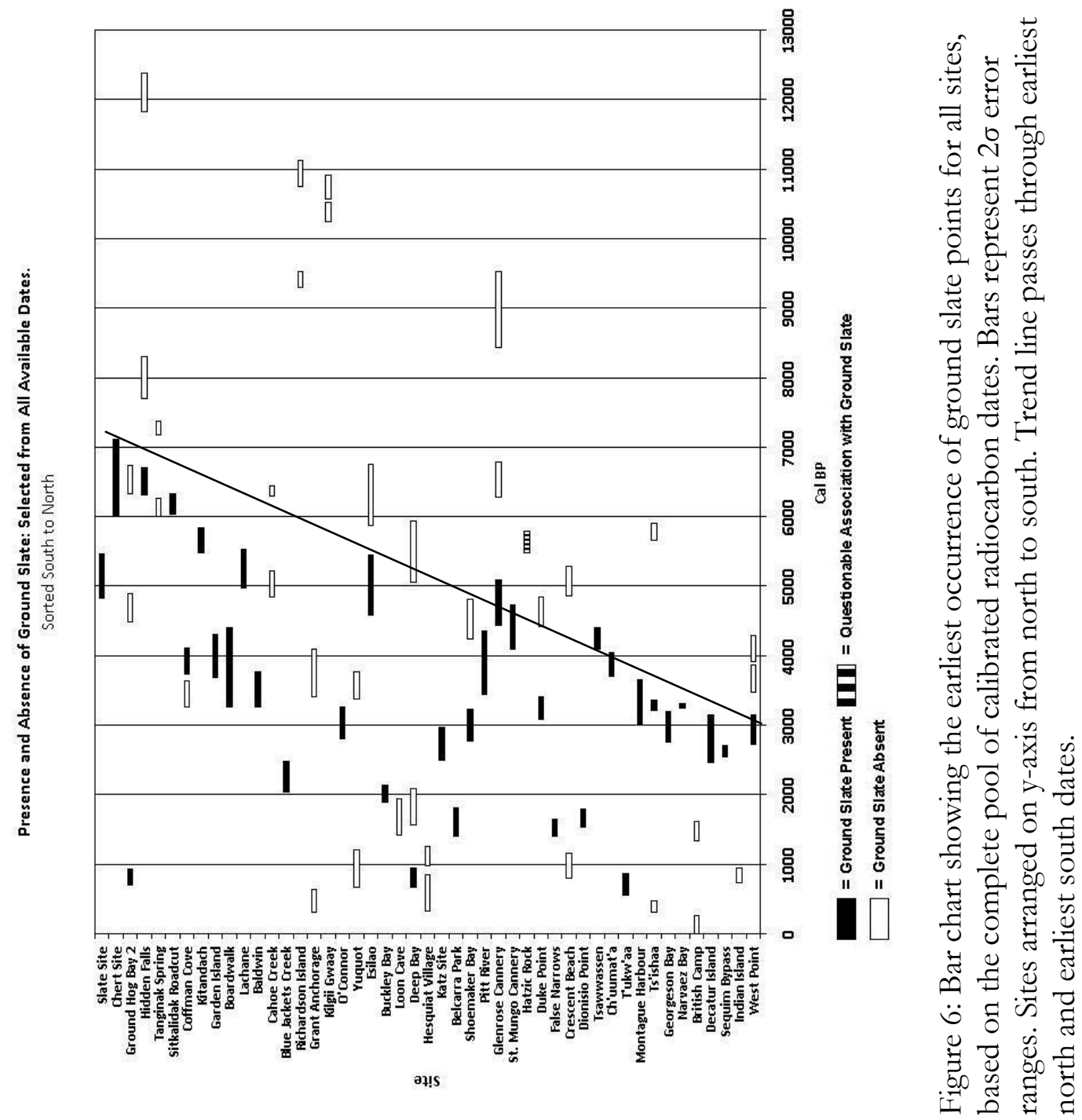


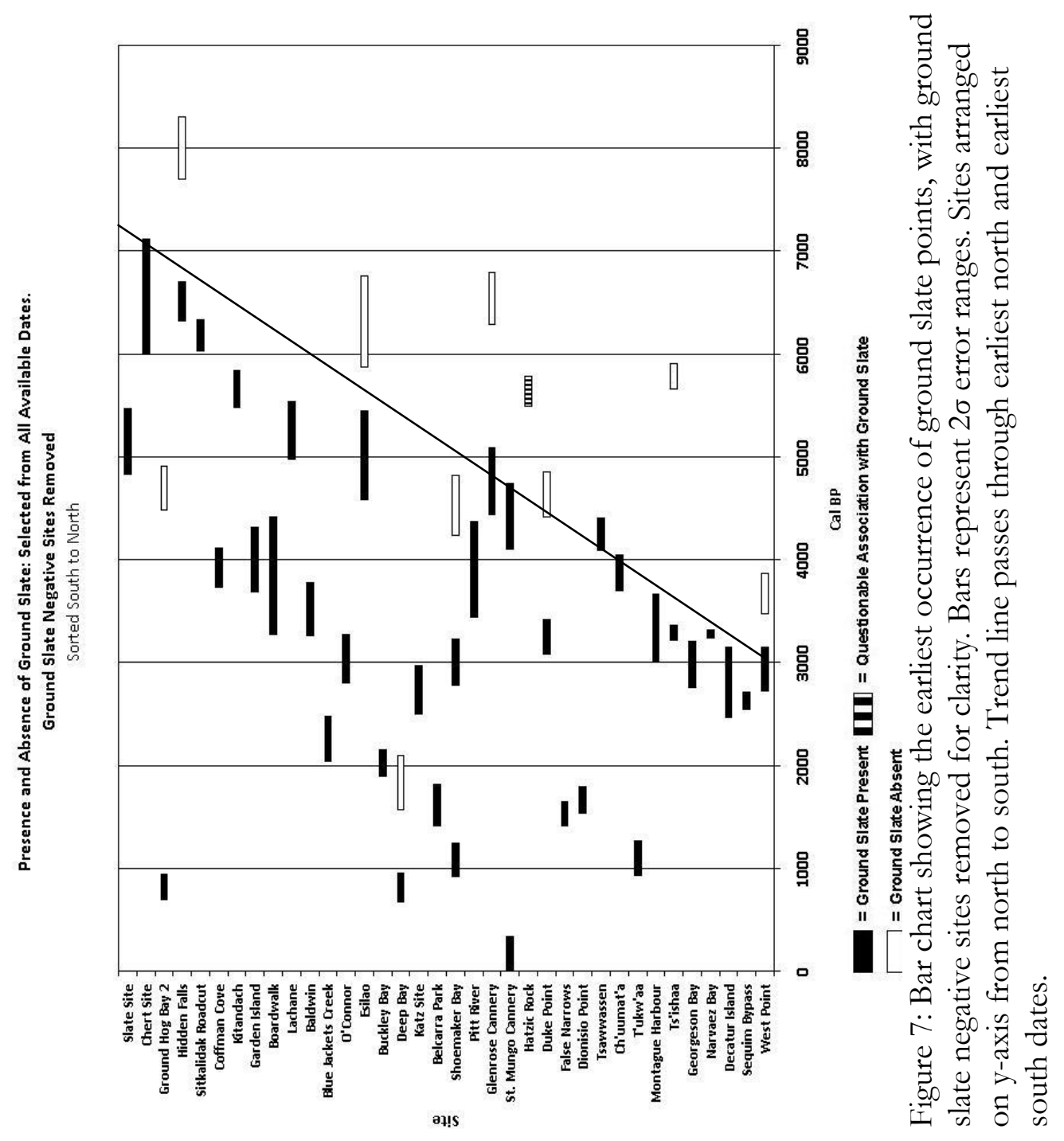




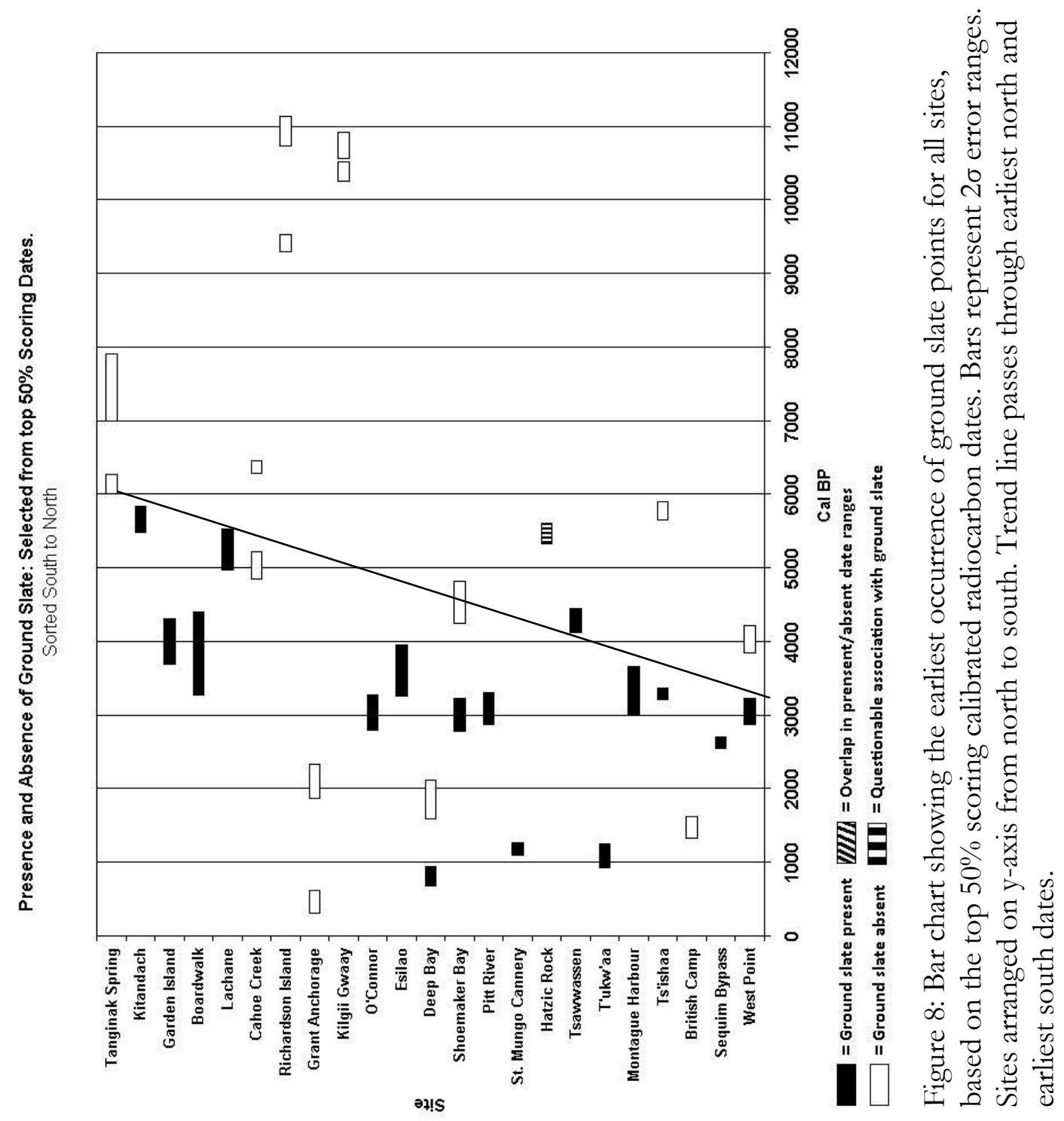




\section{Chapter 4: Discussion}

The following section provides discussion of the results of the preceding analyses, as well as discussion of information from the site reports used in this study to more fully illustrate the trends evident in my analyses.

\subsection{From Chipped to Ground?}

I will first address the implications of my analyses with regards to research question 1; did slate points in fact replace functionally comparable chipped stone technologies? Table 6 addresses whether there is in fact a relationship between chipped stone projectile points and ground slate points. There is a general consensus among researchers on the Northwest Coast that chipped stone points are supplanted, either largely or entirely by ground slate in the archaeological record (Borden 1962; Matson and Coupland 1995; Moss 2004; Ritchie 1969). By looking at slate points as a percentage of the total points recovered, we can track whether the technology is gaining or declining in prevalence throughout time. There are a number of cases which illustrate this notion of a gradual replacement of flaked points by ground points: Deep Bay, which has ground slate comprising $0.6 \%$ of the total point count in the earliest component, and $100 \%$ in the most recent. Duke Point shows a similar pattern, with no ground slate points in the earliest levels, transitioning to $60 \%$ of the point total in the latest levels. The Chert Site transitions from no ground slate points to $46 \%$ of the total in the latest components.

This trend, however, is far from universal. Assemblages from Ground Hog Bay 2 and Hidden Falls tend to go from no ground slate, to slate making up $100 \%$ of the point total, but these sites have no flaked stone component. In these cases the balance of the assemblage is frequently cobble tools, or bone and shell tools. While there is an obvious 
increasing preference for slate tools at these sites, this cannot be called a "flaked to ground" transition. Other common patterns observed in this study are assemblages dominated by ground slate from the very lowest reaches of excavation, namely the Prince Rupert Harbor sites: Baldwin, Boardwalk, Garden Island, Kitandach, and Lachane. Of course we cannot assume from this that ground slate points have "always" been employed at these sites, only that the technology has some antiquity here, and chipped stone tools are notably absent.

This leads me to the third research question posed at the beginning in of this thesis, what geographic or temporal trends exist between the adoption of slate points, either regionally or coast-wide? These patterns appear to be loosely regionally correlated; see Figure 9. This figure displays data from Table 5 geographically; assemblages with less than a 10\% ground slate to flaked stone difference between components were deemed to display no clear pattern, as I did not feel that changes this small in such a variable dataset were reliable indicators. The prevalence of sites labeled "insufficient data" usually reflects the fact that many sites have only one component, or insufficiently provenienced radiometric dates to distinguish between components using this methodology. 


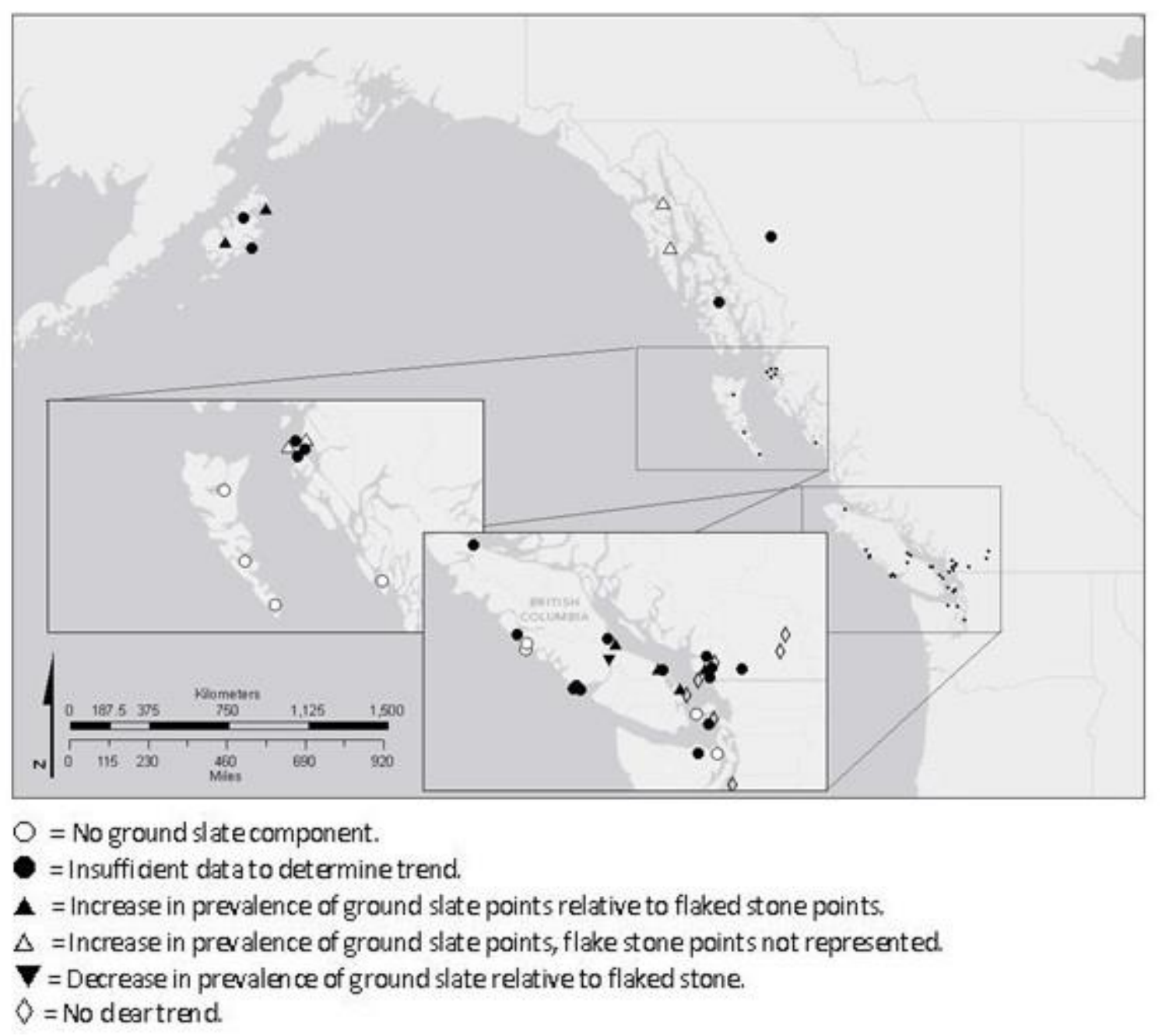

Figure 9: Geographic trends in the abundance of slate points versus flaked stone points.

There are of course limitations to drawing conclusions from this very general sort of data; one site may have been broken into components separated by hundreds of radiocarbon years, others by thousands. One site may have had 2,000 $\mathrm{m}^{3}$ excavated, anther $2 \mathrm{~m}^{3}$ (more on this problem below). Another major issue is the omission of a third category of tools prevalent on the Northwest Coast: bone and shell tools. Some of the assemblages examined in this study are dominated by bone tools, and shell tools are also fairly common. Bone tools 
could conceivably be thought of as functionally equivalent to slate and flaked stone tools, and their omission from the database was a regrettable oversight, as the waxing and waning of this technology no doubt has implications for the use of ground slate.

\subsection{The Appearance of Ground Slate on the Northwest Coast}

I will now address my second research question: when did ground slate points first appear in the archaeological record of the Northwest Coast? I will start by discussing at Figure 6, which draws upon the complete pool of dates, and provide some interpretation of the patterns evident therein. There is a general trend of ground slate points appearing earlier in the north, and later in the south; with the earliest positives at the Chert $(\sim 6,000 \mathrm{cal} \mathrm{BP})$ and Hidden Falls $(\sim 6,300 \mathrm{cal} \mathrm{BP})$ sites in Southeast Alaska, and the latest basal dates near Puget Sound (West Point, 2,900 cal BP) and the San Juan Islands (Decatur Island I/II, 2,500 cal BP). Although there are exceptions to this pattern (notably Ground Hog Bay 2),

this trend is the safest (i.e. most general) interpretation of the data. This trend is more clearly defined in Figure 7, which was constructed using the same process as Figure 6, but sites without ground slate points were omitted in an effort to remove some of the "noise" from the figure.

Figure 8 is the result of applying the results of the radiocarbon hygiene program to the data used to construct Figures 6 and 7. The bottom 50\% of the total pool of radiocarbon dates (score of less than 17) were excluded from the dataset used to make this plot. This process eliminated 53\% (26) of the sites entirely. This is unsurprising, as investigators tend to employ the same method of radiometric sampling and consistent reporting procedures throughout a site; the end result being that the only source of inter-site variability in scores came from whether or not samples were taken from features or artifacts. 
The remaining dates were then subjected to the same criteria used to select dates for Figures 12 and 13 (earliest date associated with ground slate points, closest date not associated with ground slate points). While a north to south pattern is still evident in the figure, the site selection is truncated in that it only applies as far north as Prince Rupert Harbor (Tanginak Spring, 49KOD481, was negative for ground slate). In effect, this has resulted in a more tightly focused, more reliable dataset. In this sense, the radiocarbon date culling process did what it was designed to. However, the resulting figure is not as useful in a practical sense as Figures 6 and 7, nor does it tell us anything that these figures do not. Hoping to still capitalize on the radiocarbon hygiene program, I constructed another bar chart by applying a "curved" scoring system to the pool of dates, in which only the top ranking dates for each site were used. The end result was not readily distinguishable from Figure 8.

The most evident exception to the general north to south trend in Figures 6 and 7 is the almost complete absence of the technology from the archaeological record of Haida Gwaii (also known as the Queen Charlotte Islands). This near absence is exceptional for a number of reasons. Firstly, these are island sites, with maritime adapted inhabitants (Fedje and Mathewes 2005). Secondly, it is geographically very near Prince Rupert Harbor; where ground slate points are archaeologically abundant. Lastly, only two sites on Haida Gwaii in this study, Cahoe Creek and Blue Jackets Creek, were occupied concurrently with those sites from Prince Rupert Harbor used in this study (Ames 2005; Fedje and Mathewes 2005). In fact, only two sites on Haida Gwaii used in this study had any ground stone points at all, Blue Jackets Creek (Severs 1974), and Fa'Tt 28, a considerably later site (ca. 1,100 cal BP) where one ground basalt point was recovered (Acheson 1991). 
It is worth noting, however, that the other Haida Gwaii sites discussed in this thesis, Richardson Island and Kilgii Gwaay, produced radiocarbon dates which significantly preceded those of the Prince Rupert Harbor sites, (Figures 6 and 7) so we cannot isolate geography as the only variable when making comparisons between the these sites. The exceptional rarity of ground slate points on Haida Gwaii also brings us back to the question of data sufficiency, first addressed in Section 2.4.

\subsection{Is Absence of Evidence Really Evidence of Absence?}

How can we be sure that the paucity of ground slate points from Haida Gwaii is "real" and not just a sampling issue? Although Betz and Lyman (1991) demonstrated that excavation size is directly correlated with artifact assemblage richness and diversity, my analysis showed that with regards to the assemblages used in this study, both area and volume are fairly poor predictors for the number of ground slate points recovered (area $\mathrm{R}^{2}=$ $0.436 \mathrm{p}=0.001$, volume $\left.\mathrm{R}^{2}=0.089 \mathrm{p}=0.261\right)$. Figures 4 and 5 . From my analysis, it appears that area is the better of the two, as Betz (1991) initially found. However, the high pvalue for the volume regression indicates that the analysis is suspect. Keeping this caveat in mind, we can tentatively conclude that with regard to this subset of sites, excavation size does not seem to explain all of the apparent variability in number of ground slate points recovered. This is fortunate, as had excavation size explained all the variability between assemblages, this would have been a very short thesis. In fact, no strong correlation between the variables can be unequivocally demonstrated. Further analysis of this issue would prove interesting, but unfortunately falls outside the scope of this thesis. I suspect that the discrepancy between my findings and those of Betz and Lyman are no doubt due in part to the effects of small sample size, as well as focusing in on one very specific, rare type of tool, 
rather than complete assemblages such as Betz and Lyman used. While I have concluded here that excavation size does not in itself explain the variation in the number of ground slate points recovered, in my discussion of individual sites below I treat excavated area and volume as informal measures of the robustness of my conclusions, due to Betz and Lyman's findings.

\subsection{Discussion of Individual Sites:}

In an effort to give a more complete, nuanced understanding of the variable nature of the adoption of ground slate, and to continue to account for the north to south trend, I will now discuss some regional trends in the adoption of the technology, drawing upon details from site reports. The following sites are in some cases exceptions to the general latitudinal-temporal trend, or are particularly good illustrations of it.

\subsubsection{The Northern Study Area: Kodiak Island to Haida Gwaii}

\section{Kodiak Island and Vicinity:}

The Slate (49AFO109), Chert (49AFO106), and Sitkalidak Roadcut (49KOD438) sites of Southeast Alaska provide an interesting study for the adoption of slate points. These three sites are of particular interest because the excavations clearly identify the transitional period where ground slate was adopted in southwest Alaska; the presence of slate implements are one of the demarcating elements between the Ocean Bay I and Ocean Bay II cultural phases. Also of note is the fact that these sites are in a region of interaction between Alutiiq-speaking Eskimo peoples such as the Chugach and Koniag, and the Na-Denéspeaking Eyak and Tlingit peoples.

The Sitkalidak Roadcut site is located on Sitkalidak Island which is separated from Kodiak Island by only a few kilometer of water. Don Clark (1982) characterizes this 


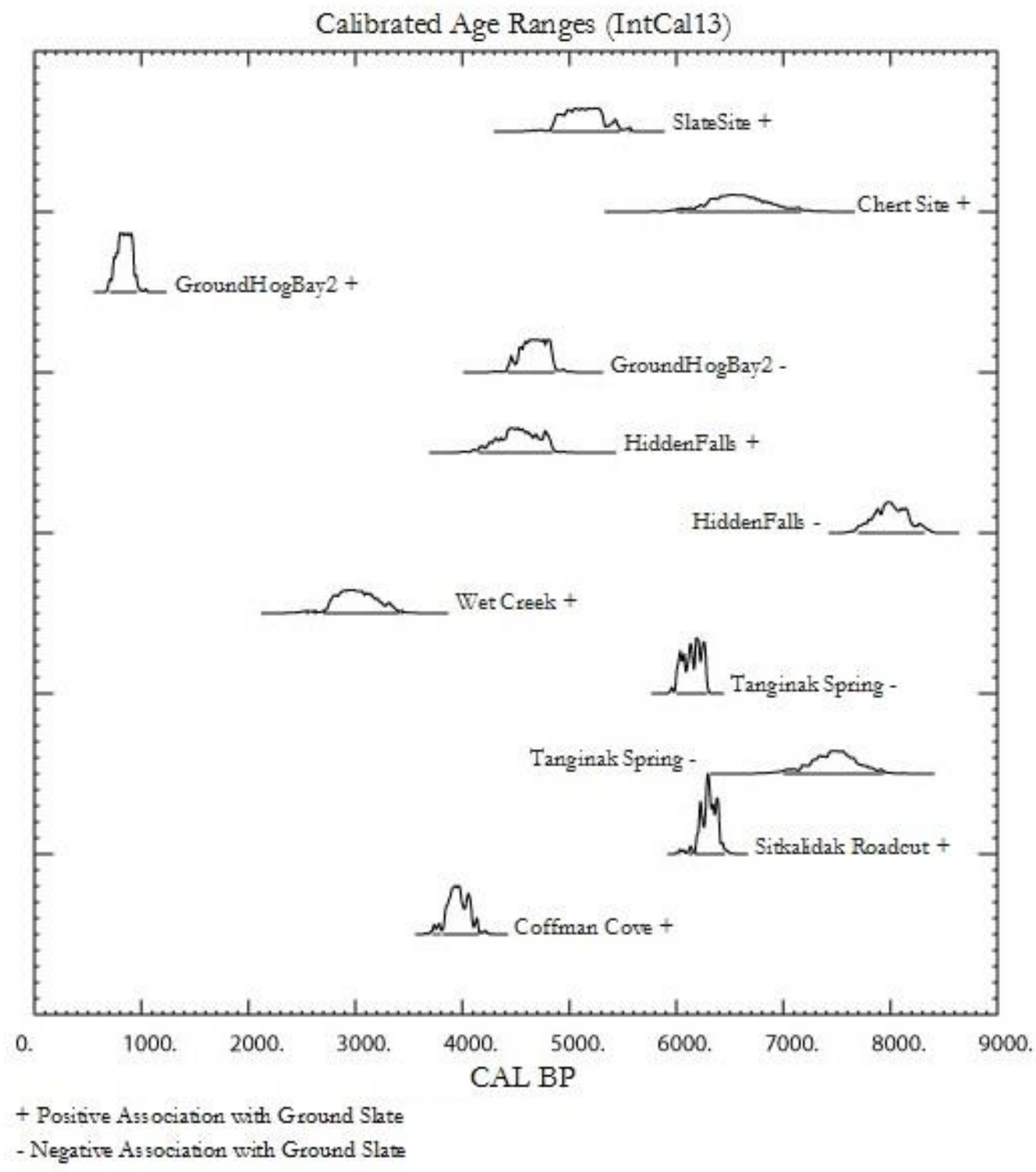

Figure 10: Radiocarbon calibration probability distribution for sites in Southeast Alaska, sites sorted north to south.

assemblage as transitioning from an overwhelmingly flaked stone dominated lithic assemblage to a ground slate-heavy assemblage. Clark notes that slate points are present in small numbers in the basal levels of the site, but continue to increase slowly in abundance while flaked stone tools fall off precipitously at the Ocean Bay I/II boundary $(\sim 4,500-4,200$ 
cal BP [Clark 1982]). This suggests that the people who inhabited the site brought with them the knowledge of working slate (all of the sites discussed in this section, Sitkalidak Roadcut, Chert, and Slate have abundant evidence of "saw-and-snap" manufacture in the form of slate bars in various stages of completion). Unfortunately, figures for excavated area and volume were unavailable for this site, but Clark gives the total number of lithic tools recovered from the site as 116 (Clark 1982:107).

The Chert Site, on Afognak Island, displays a somewhat different relationship between flaked chert tools and ground slate. This is evidence of a slate industry that is entirely absent in the lowest levels of the site (Ocean Bay I, 0 slate points, 33 chipped stone points ), but by the upper third of the occupation layer, the ground slate industry begins to rival the flaked stone industry in abundance, (Ocean Bay II, 31 slate points, 36 chipped stone points) (Clark 1982). The Chert Site does not seem to display the same drop in the abundance of flaked stone tools relative to ground slate; rather ground slate seems to represent an addition to the toolkit, slightly subordinate in number to flaked tools. Clark reports that the nearest source of tool-quality chert was some 40 kilometers away, whereas slate was available locally. Clark does not report volume for this excavation, but notes recovering 459 lithic tools (1982:109).

The Slate Site, also on Afognak Island, consists of a single component, Ocean Bay II. Accordingly, flaked stone points are absent in the lowest excavated levels. However, unlike the other Kodiak area sites discussed above, there is actually a marked increase over time in the prevalence of flaked stone implements, though they are never very common (Clark 1982). This trend is apparent from the investigator's notes, but does not appear in Table 6 , as the finest unit of subdivision is the component, not individual strata. 
Taken together, data from these three sites would suggest that while there was a marked increase in preference for ground slate implements over time in the region, flaked stone tools never fell entirely out of favor.

\section{Ground Hog Bay 2:}

The Ground Hog Bay 2 (49JUN018) site also warrants a longer look as an exception to the general north-south trend. Ground Hog Bay 2 (hereafter GHB2) is located in the fjords of southeast Alaska, at Glacier Bay. There were fewer ground slate points recovered from this site than one might expect, and they were attributed to the very latest (protohistoric) levels of the site (Ackerman 1968). The investigator reports an excavated area of $12 \mathrm{~m}^{2}$, from which two ground slate points were recovered. The trend evident in Figures 6 and 7 suggests (theoretically) that ground slate points should be appearing in this region about 5,500 to $6,500 \mathrm{cal} \mathrm{BP}$, but the first occurrence can only be attributed to a strata dating to about 1,100 cal BP. GHB2 is located very near to the Hidden Falls site, where ground slate points are well represented. Ground slate points to show up at Hidden Falls at 42004850 cal BP (Davis 1989). The number of tools recovered from the lower strata of the site, as well as the presence of ground slate points in only the upper strata of this site suggests that this is a real absence, and not a sampling issue.

Prince Rupert Harbor and Vicinity:

The Prince Rupert Harbor sites used in this study: Baldwin (GbTo-36), Boardwalk (GbTo-31), Garden Island (GbTo-23), Kitandach (GbTo-34), and Lachane (GbTo-33) represent archetypical Northwest Coast maritime assemblages, and given their proximity to one another are treated together. Most site excavations focused on midden material with very complex stratigraphy indicative of "cut and fill" activities. Features such as hearths, 
postmolds, burials, and canoe skids indicate that these sites were likely stable, long term (if perhaps seasonal) occupations.

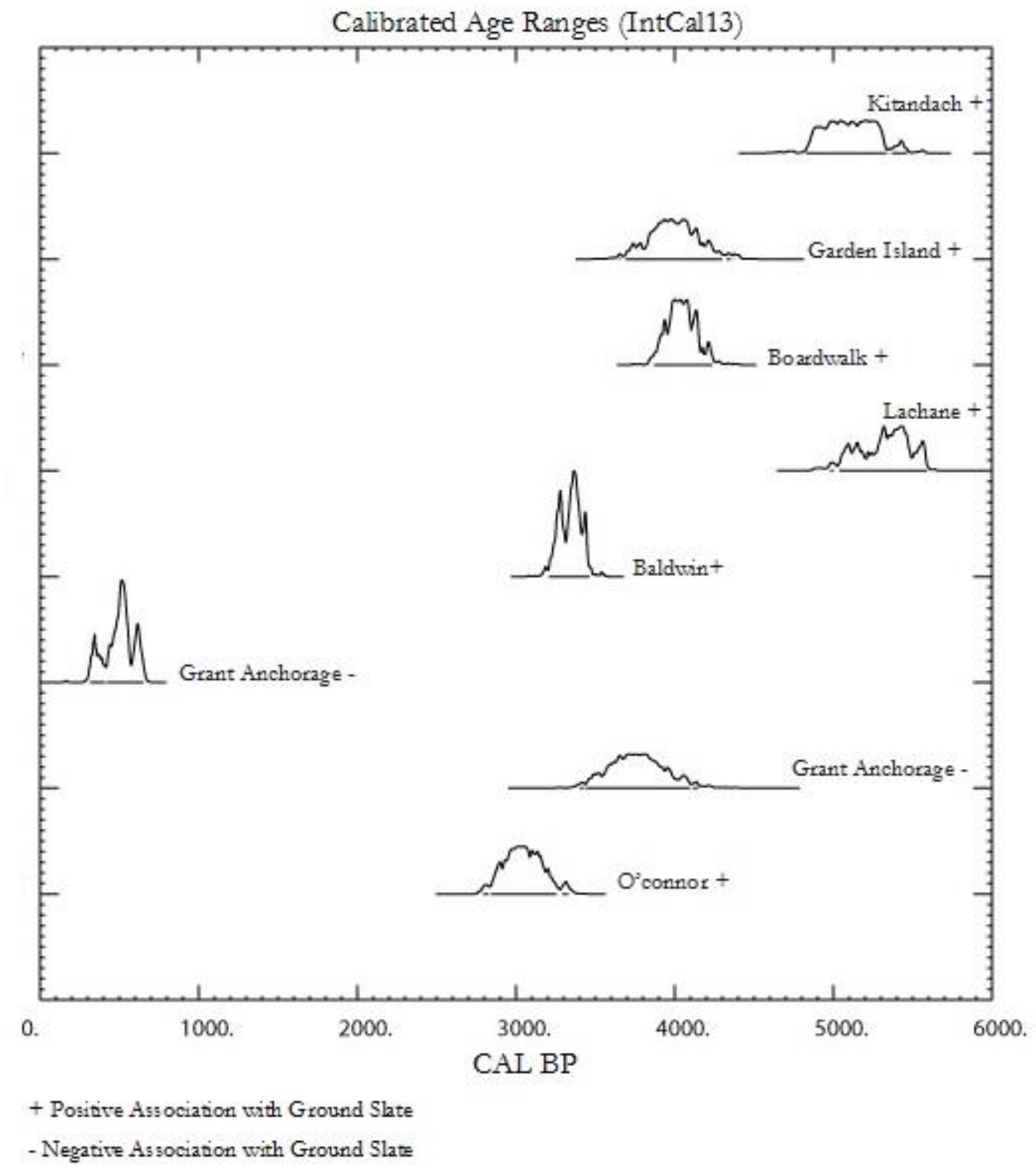

Figure 11: Radiocarbon calibration probability distribution for sites in Prince Rupert Harbor and other sites on the central British Columbia coast. Note that Kitandach, Garden Island, Boardwalk, Lachane, and Baldwin are in such close proximity that the north-south sorting of these five sites is not significant. 
This fact, coupled with some of the largest excavations of any sites used in this study (Baldwin: $208 \mathrm{~m}^{3}$, Boardwalk: $1032 \mathrm{~m}^{3}$, Garden Island: $297 \mathrm{~m}^{3}$, Kitandach: $1655 \mathrm{~m}^{3}$ Lachane: $1000 \mathrm{~m}^{3}$ ) has resulted in the recovery of an extensive ground slate assemblage. Bifacially flaked tools are notably absent. Despite abundant slate points, cobble tools and bone tools dominate these assemblages (Ames 2005). The Prince Rupert Harbor assemblages exemplify the pattern of a preference for ground slate points from the very lowest reaches of the excavations, indicating the technology was likely well-established prior to the occupation of Prince Rupert Harbor sites.

\section{Grant Anchorage:}

The Grant Anchorage site (Tc'Te-4) is located some some $250 \mathrm{~km}$ south of Prince Rupert Harbor, and 200 Kilometers southeast of the Richardson Island site on Haida Gwaii. The Grant Anchorage assemblage is dominated by various bifacially flaked projectile points, as well as bone points. With a reported excavated area of $54 \mathrm{~m}^{2}$ (volume was not reported), I am disinclined to think that the excavations here meet the $100 \mathrm{~m}^{3}$ per 1,000 radiocarbon years threshold, due to the small excavated area. While there is nothing in this artifact assemblage that can be called a ground slate point per se, the investigator reports a number of ground slate objects of uncertain purpose, likely abraders, and one object that exhibits the "saw-and-snap" manufacturing characteristic of some types of ground slate points (Simonsen 1973). The case for a true absence of ground slate points here is considerably less robust than on Haida Gwaii; this absence might theoretically be accounted for by the abundance of bone points 


\section{Haida Gwaii}

The sites located on Haida Gwaii used in this study are of particular note, as ground slate technology appears to be very rare here.

The Cahoe Creek site (FjUb-10) is located on the shores of the Masset Inlet, a saltwater inlet on Graham Island. The site is close to $50 \mathrm{~km}$ from the open sea by boat, and approximately $20 \mathrm{~km}$ from the sea overland. The investigators characterize the site as a "primarily maritime adapted semi sedentary camp or village" (Christensen and Stafford 2005:271). Excavations occurred in a shell midden. In terms of the faunal assemblage, land mammal elements outnumber sea mammal elements, with fish more abundant than both (Christensen and Stafford 2005). The assemblage is characterized by microblades and cores, bone points, and cobble tools. Excavated volume is not available for the site, but my estimate for excavated area, based on maps of the excavations (Christensen and Stafford 2005:247) is approximately $10 \mathrm{~m}^{2}$. 


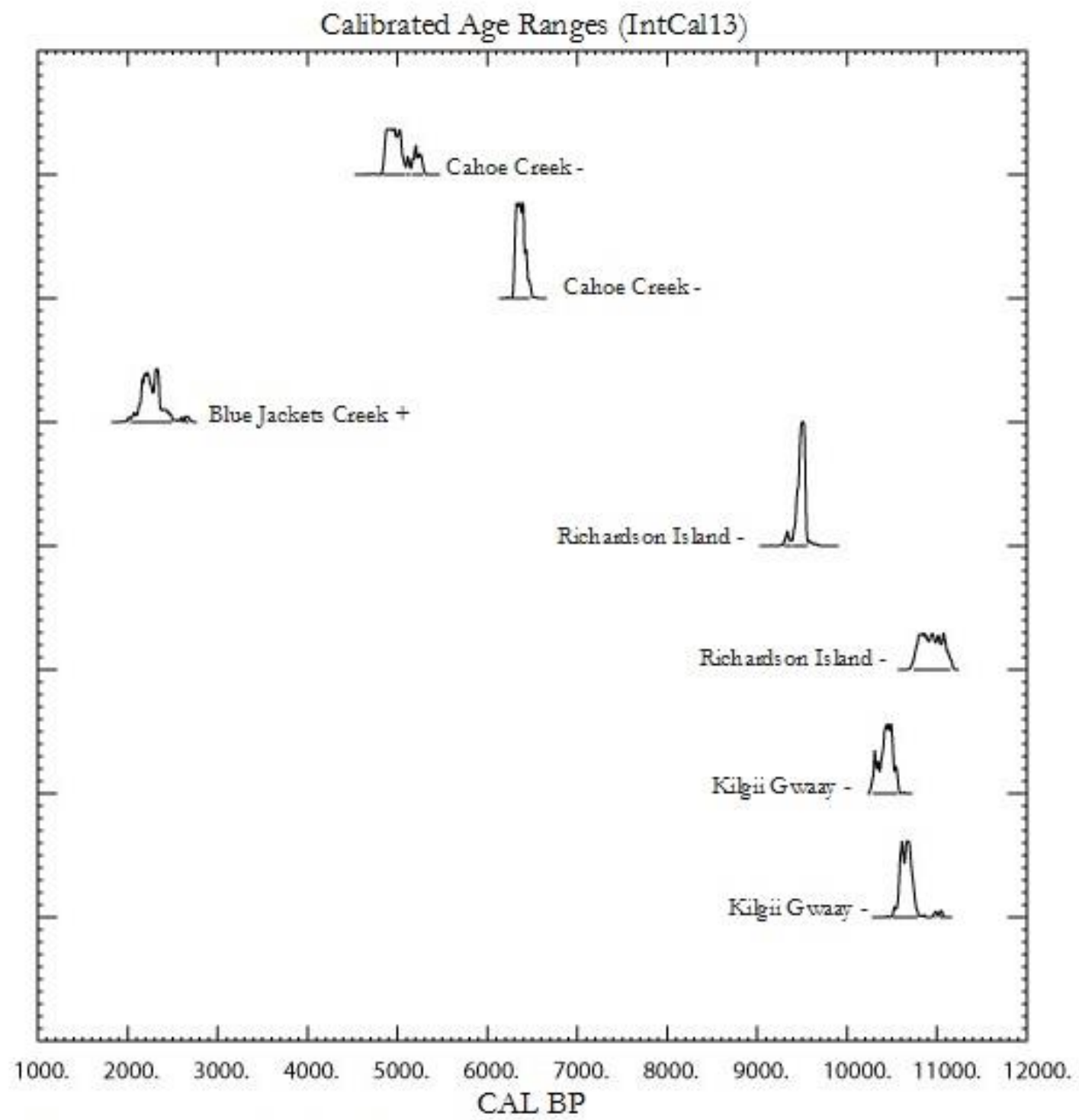

+ Positive Association with Ground Slate

- Negative As sociation with Ground Slate

Figure 12: Radiocarbon calibration probability distribution for sites on Haida Gwaii (Queen Charlotte Islands), sites sorted north to south.

The Richardson Island site (1127T) is located on a small island in southeastern Haida Gwaii. The lithic assemblage from the site is characterized by microblades/cores, which in later levels transition to a biface-heavy industry (Fedje, et al. 2005). The site has good chronological control, with 16 AMS dates. Faunal remains were scarce, mostly calcined 
bone, though both fish and large mammals were identified (ibid). The total excavated area is $2.5 \mathrm{~m}^{2}$. Excavated volume was not reported.

Although neither of two these sites almost certainly do not satisfy Lyman's $100 \mathrm{~m}^{3}$ per 1,000 years suggested criteria (due to their small area), my sense is that ground slate is rare on Haida Gwaii, based upon the fact that Fedje and Mathewes (2005) found no ground slate points at any other of the eight excavations reported in that work. Additionally, the lithic assemblages they reported (microblades and cores, heavy bifaces) are fundamentally different from the neighboring Prince Rupert assemblages.

The site of Blue Jackets Creek is located on the northern end of Graham Island, on Masset Inlet. Data for this site is scarce, but excavations carried out in 1973 by Severs (Severs 1974) are briefly reported. This site represents a considerably later occupation than the other Haida Gwaii sites noted above, with dates spanning from 2,840-4,124 cal BP $(2,720 \pm 85$ to $3,750 \pm 145$ RCY BP) (Severs 1974:199). The Blue Jackets Creek artifact assemblage is dominated by stone tools. Cobble choppers and adze performs were most common. Bifacially flaked tools were exceptionally rare. There were also a number of ground slate blades and points recovered, though the number of points and their specific context was not reported; Severs only notes that they were found in the "upper levels of the site" (Severs 1974:191).

Acheson, in his extensive work on southern Haida Gwaii reports finding one ground basalt point at FaTt 28, a shell midden on Moresby Island, but no slate points were reported. Basal layers of this midden dated to 920-1,185 cal BP (1,120 \pm 70 RCY BP) (Acheson 1991), which provides further evidence for the rarity of ground stone points on Haida Gwaii, even during later periods. Orchard (2007), in his work on southern Haida Gwaii, 
likewise did not recover any ground slate points from starta dating to as late as the Late Pacific period.

4.4.2 The Southern Study Area: Vancouver Island, the Salish Sea, and the Fraser River The southern end of my study area presents a more complicated picture of the relationship between the use of ground slate and flaked stone points than do the more northerly sites discussed above, but also greater potential for information. The majority of sites looked at in this study are located in the southern study area, which is considerably better studied than other portions of the Pacific Northwest coast (e.g. Alexander Archipelago in Southeast Alaska), and this much larger dataset results in more "noise", i.e. the north to south trend evident in the northern study area is not as clear with these sites. I will start by examining region-wide trends, and then site-by-site analysis. 


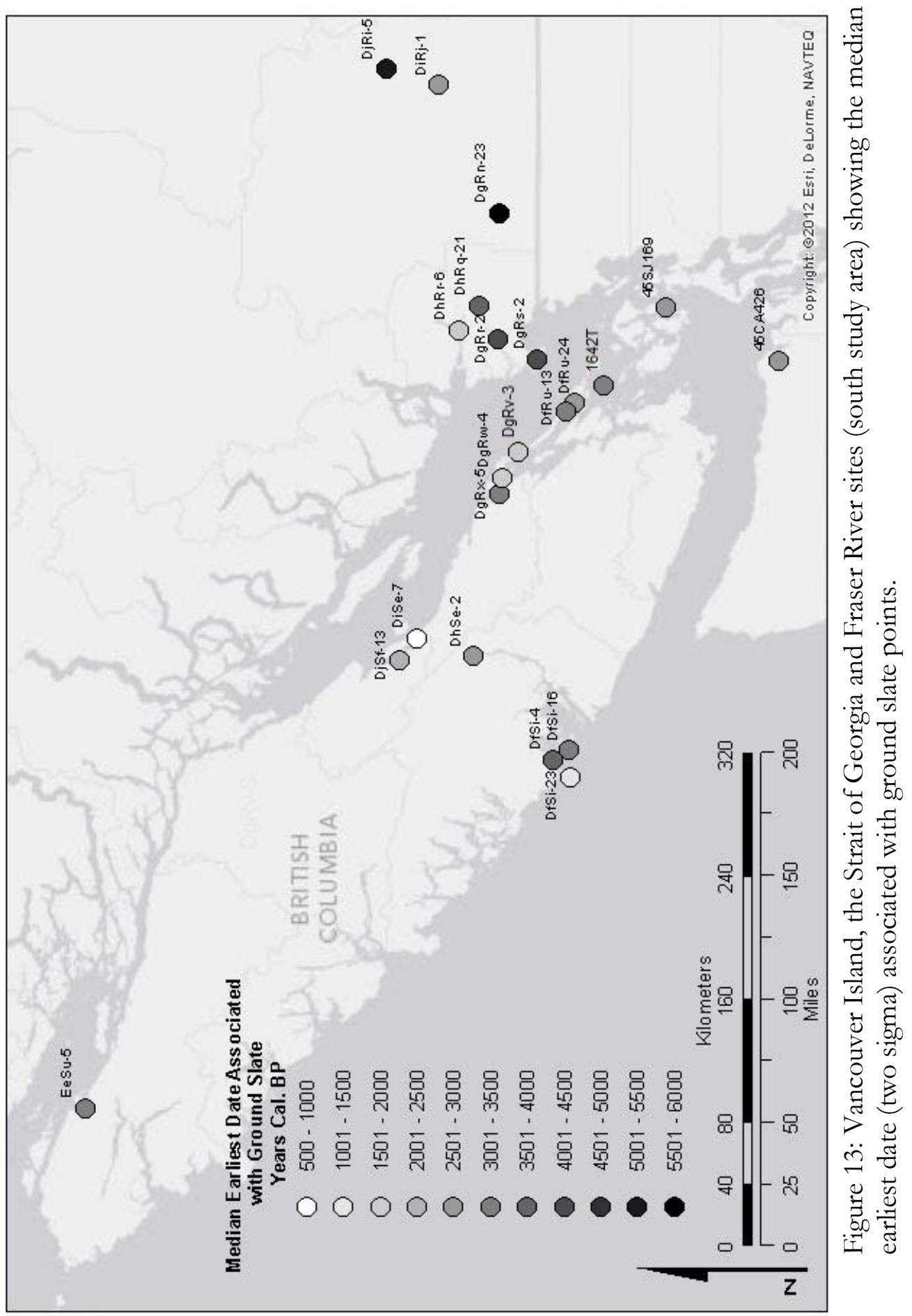




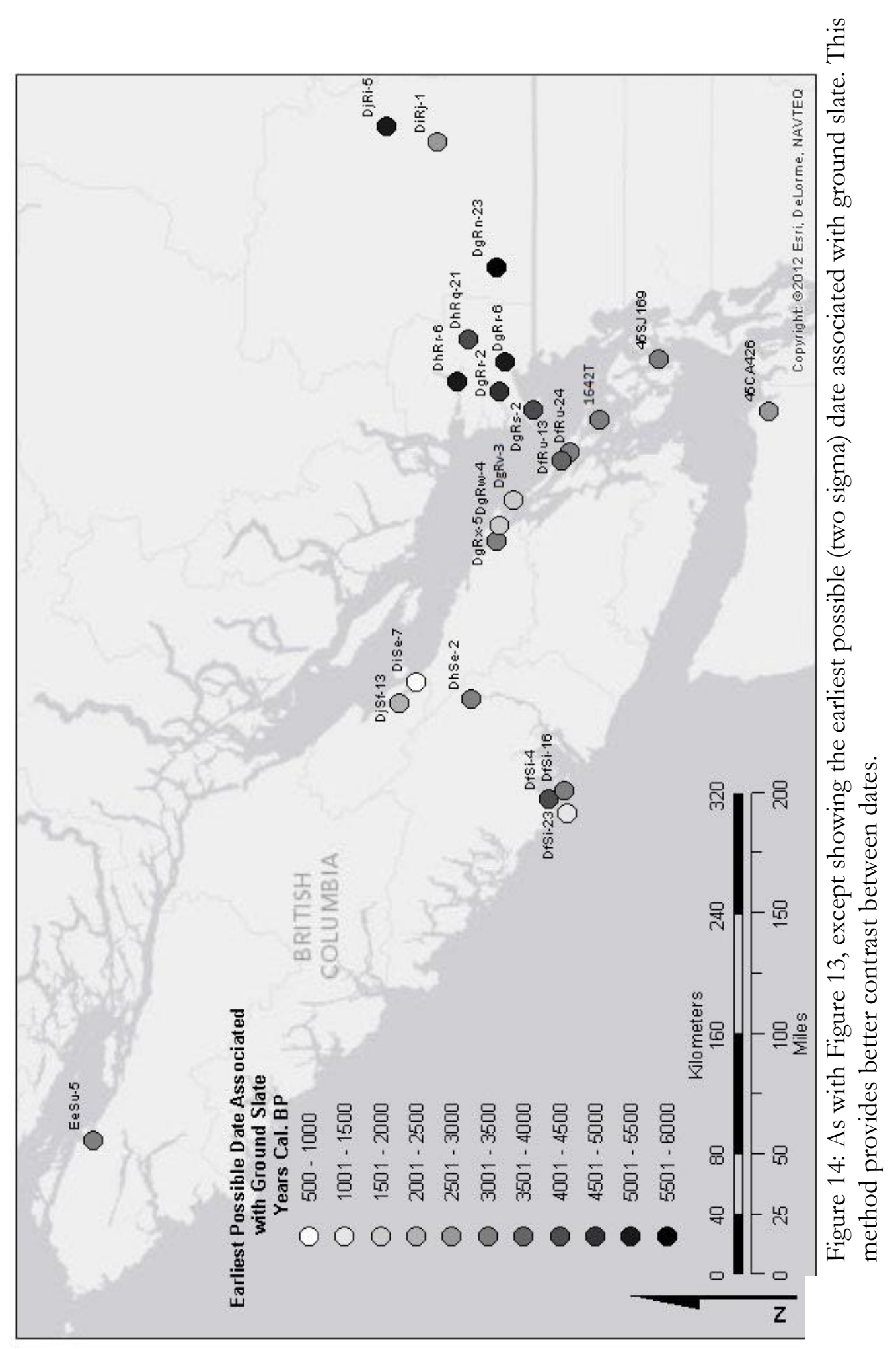


There is no question that the oldest occurrence of ground slate points in the region is on the Fraser Delta and Lower Fraser River. This runs counter to what I had expected when I first began collecting data in the region: I initially hypothesized that the technology came down the west coast of Vancouver Island (for a time DiSf-4, Ch'uumat'a, was the earliest occurrence). The data do not support this hypothesis. Having the earliest dates for slate points occur on and at the mouth of the Fraser River is in keeping with the north to south trend evident in Figures 6 and 7, but this presents a functional complication, in that it does not reflect the geographic realities of the region. The western interior of British Columbia is a rugged, mountainous country bisected by deep canyons and fjords- substantial barriers to travel, and accordingly, the spread of information. The coastline, however, presents a veritable highway system of waterways, sheltered from the open ocean by islands- a Pacific Aegean in which skilled canoe crews could cover vast distances with relative ease (Ames 2002). The question then arises: why should slate points appear to have been first adopted along a corridor to the interior? I will return to the question in section 4.6.

The Fraser River and Fraser Delta:

Esilao (DjRi-5) represents both one of the earliest dates for ground slate points in the southern study area, as well as the furthest site up the Fraser River used in this study. Slate points are exceedingly rare $(n=2)$, but as would be expected for a riverine environment, transverse slate knives are abundant ( $\mathrm{n}=232$, including fragments) (Mitchell 1963). Furthermore, the two points recovered from Esilao are atypical in form; 7-8 $\mathrm{cm}$ in length, with rough (not finely ground) stemmed bases. Compare to the points from Deep Bay (DiSe-7) shown in Figure 1 (a-d). Note, however, that the points from Deep Bay are considerably later in time. Additionally, one of the specimens from Esilao is rectangular in 
cross section for almost the entire length of the tool, except for $3 \mathrm{~cm}$ in the middle of the point, which has been beveled to an edge.

Table 7: Relative proportions of slate points, slate knives, and flaked points for sites in the southern study area.

\begin{tabular}{|c|c|c|c|c|c|c|c|}
\hline & $\begin{array}{l}\text { Slate } \\
\text { Points }\end{array}$ & $\begin{array}{l}\text { Slate } \\
\text { Knives }\end{array}$ & $\begin{array}{l}\text { Flaked } \\
\text { Stone } \\
\text { Points }\end{array}$ & Total & $\begin{array}{l}\text { \% Slate } \\
\text { Points }\end{array}$ & $\begin{array}{l}\% \text { Slate } \\
\text { Knives }\end{array}$ & $\begin{array}{l}\% \text { Flaked } \\
\text { Points }\end{array}$ \\
\hline \multicolumn{8}{|l|}{ Fraser River } \\
\hline Esilao & 4 & 232 & 113 & 349 & $1.15 \%$ & $66.48 \%$ & $32.38 \%$ \\
\hline Glenrose Cannery & 14 & 33 & 40 & 87 & $16.09 \%$ & $37.93 \%$ & $45.98 \%$ \\
\hline Hatzic Rock* & $5^{*}$ & $5^{*}$ & 42 & 47 & $10.64 \% *$ & $10.64 \% *$ & $89.36 \%$ \\
\hline Katz Site & 17 & 474 & 71 & 562 & $3.02 \%$ & $84.34 \%$ & $12.63 \%$ \\
\hline Pitt River & 12 & 13 & 15 & 40 & $30.00 \%$ & $32.50 \%$ & $37.50 \%$ \\
\hline St. Mungo Cannery & + & + & + & $\mathrm{n} / \mathrm{a}$ & $\mathrm{n} / \mathrm{a}$ & $\mathrm{n} / \mathrm{a}$ & $\mathrm{n} / \mathrm{a}$ \\
\hline \multicolumn{8}{|l|}{ Fraser Delta } \\
\hline Tsawassen & 11 & 91 & 21 & 123 & $8.94 \%$ & $73.98 \%$ & $17.07 \%$ \\
\hline Belcarra Park & 97 & 65 & 130 & 292 & $33.22 \%$ & $22.26 \%$ & $44.52 \%$ \\
\hline \multicolumn{8}{|l|}{ Strait of Georgia } \\
\hline Montague Harbor & 29 & 10 & 26 & 65 & $44.62 \%$ & $15.38 \%$ & $40.00 \%$ \\
\hline Dionisio Point & + & + & + & $\mathrm{n} / \mathrm{a}$ & $\mathrm{n} / \mathrm{a}$ & $\mathrm{n} / \mathrm{a}$ & $\mathrm{n} / \mathrm{a}$ \\
\hline Narvaez Bay & + & $?$ & $?$ & $\mathrm{n} / \mathrm{a}$ & $\mathrm{n} / \mathrm{a}$ & $\mathrm{n} / \mathrm{a}$ & $\mathrm{n} / \mathrm{a}$ \\
\hline Georgeson Bay & 24 & 14 & 19 & 57 & $42.11 \%$ & $24.56 \%$ & $33.33 \%$ \\
\hline Duke Point & 42 & 36 & 44 & 122 & $34.43 \%$ & $29.51 \%$ & $36.07 \%$ \\
\hline False Narrows & 56 & 125 & 75 & 256 & $21.88 \%$ & $48.83 \%$ & $29.30 \%$ \\
\hline Decatur Island I/II & 3 & 2 & 4 & 9 & $33.33 \%$ & $22.22 \%$ & $44.44 \%$ \\
\hline Buckley Bay & 7 & 6 & 0 & 13 & $53.85 \%$ & $46.15 \%$ & $0.00 \%$ \\
\hline Deep Bay & 15 & 8 & 22 & 45 & $33.33 \%$ & $17.78 \%$ & $48.89 \%$ \\
\hline O'Connor & 3 & 0 & 0 & 3 & $100.00 \%$ & $0.00 \%$ & $0.00 \%$ \\
\hline \multicolumn{8}{|l|}{ Olympic } \\
\hline \multicolumn{8}{|l|}{ Peninsula/ Puget } \\
\hline \multicolumn{8}{|l|}{ Sound } \\
\hline West Point & 1 & 1 & 27 & 29 & $3.45 \%$ & $3.45 \%$ & $93.10 \%$ \\
\hline Sequim Bypass & 17 & 1 & 16 & 34 & $50.00 \%$ & $2.94 \%$ & $47.06 \%$ \\
\hline \multicolumn{8}{|l|}{ Western } \\
\hline \multicolumn{8}{|l|}{ Vancouver Island } \\
\hline Ch'uumat'a & 2 & 2 & 0 & 4 & $50.00 \%$ & $50.00 \%$ & $0.00 \%$ \\
\hline Ts'ishaa & 6 & 2 & 0 & 8 & $75.00 \%$ & $25.00 \%$ & $0.00 \%$ \\
\hline T'ukw'aa & 3 & 0 & 0 & 3 & $100.00 \%$ & $0.00 \%$ & $0.00 \%$ \\
\hline Shoemaker Bay & 92 & 8 & 35 & 135 & $68.15 \%$ & $5.93 \%$ & $25.93 \%$ \\
\hline
\end{tabular}

*As was noted previously, the slate tools from Hatzic Rock (DgRn-23) cannot be unequivocally deemed to be either points or knives.

Mitchell feels that this point is a complete tool (not in a state of manufacture), but does not speculate as to the purpose of this edge treatment (Mitchell 1963). Unfortunately, 
there are no photographs of these points. Though it is evident that slate points were present at Esilao at this early date, these two points do not constitute an industry per se. The case can be made that these points represent an experimental technology, or perhaps an outgrowth of the local slate knife industry.

Just downriver from Esilao, the Katz site (DiRj-1) presents a different picture of ground slate use: slate points, as well as knives, are found in relative abundance here, and are found in various stages of manufacture and repair (reshaping of broken implements) (Hanson 1973). While slate points are well-represented here, they are significantly outnumbered by both slate knives and flaked stone points. This suggests a quintessential generalized terrestrial/riverine/maritime economy, as we might expect given the site's location (Table 5). The Katz Site ( 3,000-2,500 cal BP), is considerably younger than Esilao $(5,500-4,600 \mathrm{cal} \mathrm{BP})$, however, it is clear that a slate point industry was well established at the time of occupation.

Downriver from Esilao is the Hatzic Rock site (DgRn-23). This site offers an example of the ambiguity involved in assigning artifacts to arbitrary classes. The lithic assemblage at Hatzic Rock is characterized by pebble tools in its lowest components, transitioning to a more generalized lithic industry with diverse biface forms in upper components. Pebble tools are abundant throughout. Ground slate tools are rare, consisting of the usual abraders, as well as five fragments of slate blades (Mason 1994). When these fragments are refitted, the blades are approximately $2 \mathrm{~cm}$ by $15 \mathrm{~cm}$, stemless, and lanceolate in shape. The cross section shape was not reported. The investigator classifies these artifacts as cutting implements (knives), but their form certainly resembles the lanceolate slate points common in the northern study area (see Figure 1). Even if these implements are in fact 
knives, the techniques used to make them would be very similar to slate points. It is unclear from the text of the report whether the implements are bifacially or unifacially ground.

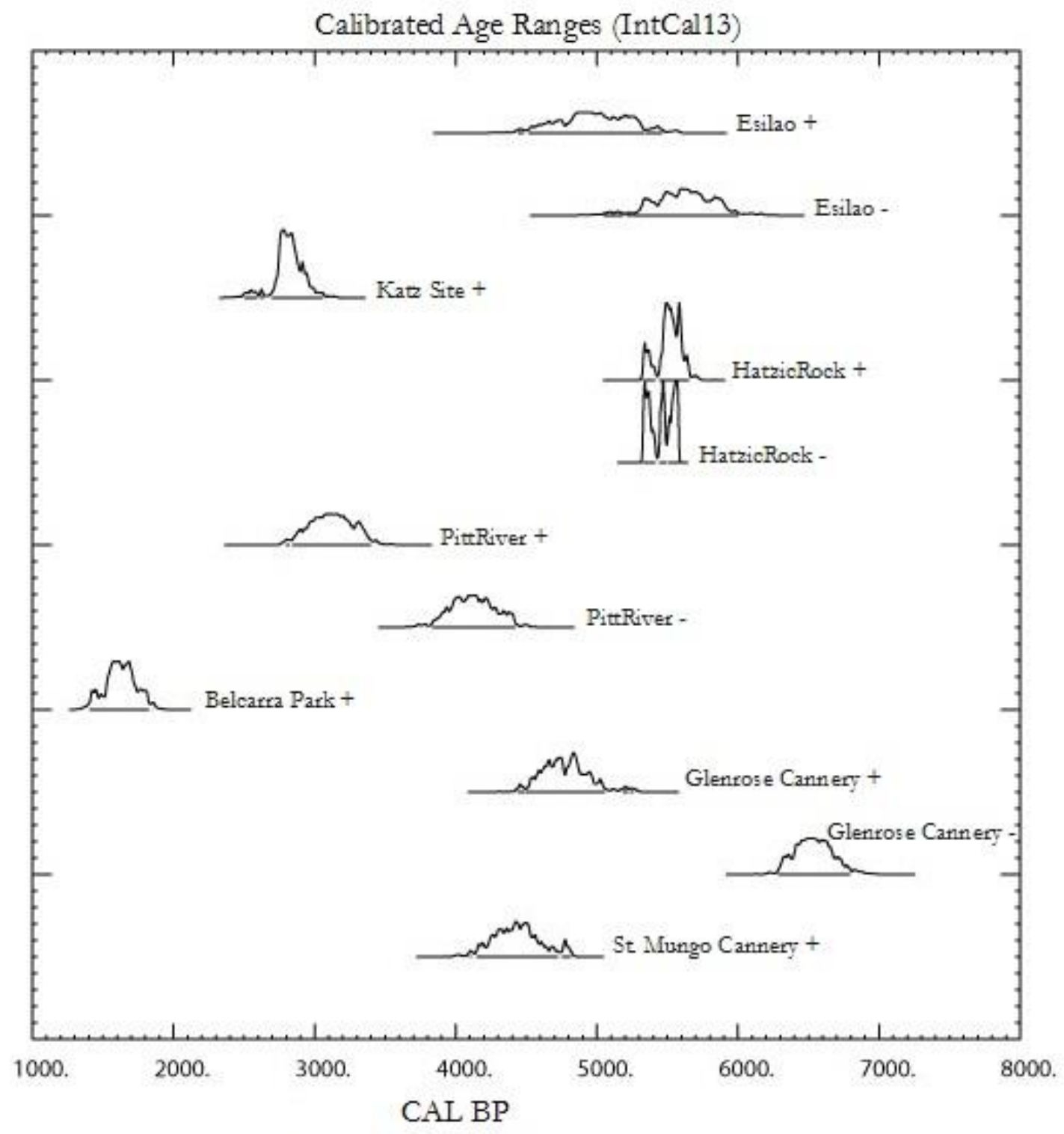

+ Positive Ass ociation with Ground Slate

- Negative As sociation with Ground Slate

Figure 15: Radiocarbon calibration probability distribution for sites on the Fraser River, sites sorted upriver to downriver. 
Given this functional ambiguity, coupled with the somewhat anomalously early ground slate points date range of 5,600-5,300 cal BP, I have opted not to unequivocally assign Hatzic Rock a ground slate point positive distinction.

A more chronologically comparable ground slate assemblage to the one found at Esilao ( 5,500- 4,600 cal BP) can be found at the Glenrose Cannery site $(\sim 4,400-5,000 \mathrm{cal}$ BP). The slate points from Glenrose are usually either triangular or occasionally leaf shaped in form. While slate points are still outnumbered by slate knives and flaked stone points, the differences are less marked than at either Esilao or Katz (Table 5).

The Strait of Georgia:

The site of Deep Bay (DiSe-7) is slightly problematic. The site shows an anomalously late date for the first appearance of ground slate compared to its neighbors (Figure 16). However, this site presents one of the best stratigraphic illustrations of the appearance of ground slate of any site in the southern study area. I estimate that excavations at the site were roughly $60 \mathrm{~m}^{3}$. There was a clear decline at the site in the prevalence of flaked stone points relative to ground stone points over time, and the investigator has radiometric dates for the strata on either side of the first appearance of ground slate points, which came into use at Deep Bay sometime between 1,853-823 cal BP (1,910 \pm 110 and $900 \pm 90$ RCY BP) (Monks 1977). There is one piece of ground slate which appears in the earliest component at Deep Bay (Table 4), but the investigator believes it to be intrusive, as it is very near the component I/II boundary (Monks 1977). At present, I cannot present a satisfactory explanation for why such a clear transition should appear so late, other than perhaps while the technology may have been known regionally for some time, the occupants of Deep Bay 
had little use for it at first. I also cannot definitively rule out the possibility that this late date represents a sampling issue.

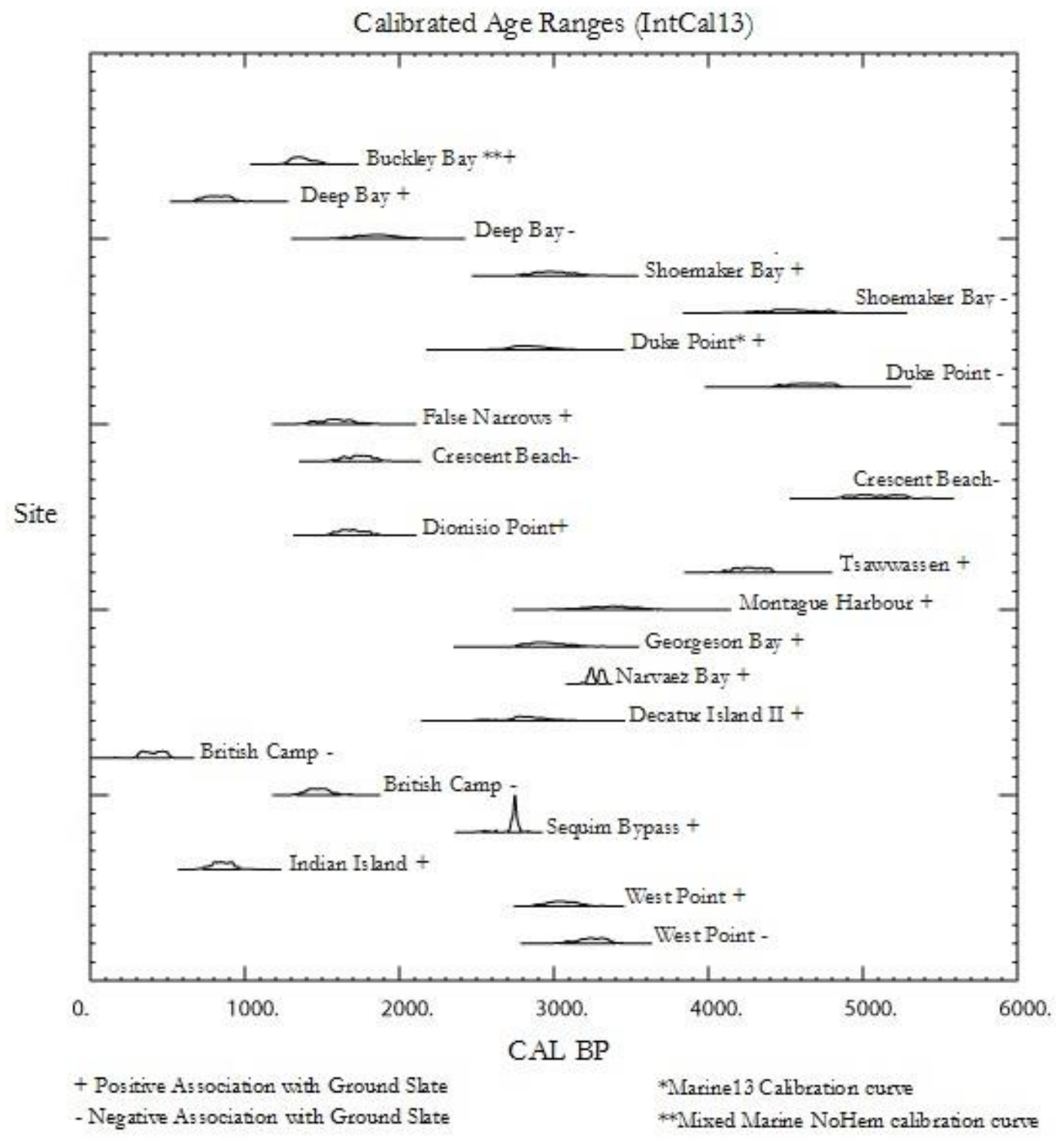

Figure 16: Radiocarbon calibration probability distribution for sites on the east coast of Vancouver Island and other sites in the Salish Sea, sites sorted north to south. 
Approximately $70 \mathrm{~km}$ down the coast of Vancouver Island from the Deep Bay site is the Duke Point site (DgRx-5). Like Deep Bay, this site illustrates the classic replacement of flaked stone points with ground slate. While slate points come to dominate the point assemblage at Duke Point, not to the degree that they do at Deep Bay. Additionally, the slate points from Duke Point seem to be more variable in form, with triangular, stemmed, and unstemmed varieties represented. Chipped and ground slate points are also present in very small numbers (Murray 1982). The investigator also notes unusual edge treatments for some of the slate points, asymmetrical beveling for example.

The ground slate assemblage from Duke Point cannot be as closely associated with radiometric dates as Deep Bay, but I believe the earliest occurrence to be between 4,6553,288 cal BP (4,130 \pm 100 and 3,490 \pm 100 RCY BP) (Morlan 2005). I again can offer no strong explanation as to why two sites separated by less than $100 \mathrm{~km}$ (Duke Point and Deep Bay) can display so similar a flaked-to-ground transition which would seem to begin more than 1500 years apart, other than the fact that the finest unit of measure for associating artifacts with dates here is the component, rather than individual strata, as was the case at Deep Bay. It is worth noting, however, the date spans of Component III of both Deep Bay and Duke Point; regardless of the earliest appearance of slate points, they come to dominate the point total around the same time, roughly 900-700 cal BP. This lends credence to the notion, posited above, that while slate points had been known for some time, something happened (e.g. a change in prey choice, or the advent of compound seal mammal hunting gear) to make them a more attractive technological choice. 
Table 8: Comparison of Components: Duke Point (DgRx-5) and Deep Bay (DiSe-7).

\begin{tabular}{|c|c|c|c|c|c|}
\hline Site/Component & $\begin{array}{c}\text { Ground } \\
\text { Points }\end{array}$ & $\begin{array}{c}\text { Flaked } \\
\text { Points }\end{array}$ & $\begin{array}{c}\% \text { Slate } \\
\text { Points of } \\
\text { Total Points }\end{array}$ & $\begin{array}{c}\text { Date Span: } \\
\text { cal BP }\end{array}$ & $\begin{array}{c}\text { Date Span: } \\
\text { RCY BP }\end{array}$ \\
\hline Duke Point III & + & + & $60 \%$ & $680 \pm 90$ & $768-522$ \\
Deep Bay III & + & - & $100 \%$ & $460 \pm 90$ & $646-308$ \\
Duke Point II & + & + & $20 \%$ & $3,490 \pm 100$ & $3,992-3,550$ \\
Deep Bay II & + & + & $65 \%$ & $900 \pm 90$ & $961-676$ \\
Duke Point I & + & + & $12 \%$ & $4,130 \pm 100$ & $4,864-4,414$ \\
Deep Bay I & + & + & $6 \%$ & $2,630 \pm 100$ & $2,955-2,425$ \\
\hline
\end{tabular}

Further down the west coast of Vancouver Island, on Galiano Island, is the Montague Harbor site (DfRu-13). Like other sites in the region, Montague Harbor shows a marked increase in the prevalence of ground slate in the most recent occupational layers at the expense of flaked stone points (Mitchell 1971). Unfortunately, we only have radiocarbon dates for the earliest and latest of the three components identified by the investigator. Ground slate points are present in small numbers in the earliest component, which spans between 3,600-2,750 cal BP (3,160 \pm 130 and 2,890 \pm 140 RCY BP) (Mitchell 1971). Ground slate points come to dominate the point totals about 930-530 cal BP (790 \pm 130 RCY BP), again, much like other sites in the region.

The three inner-coast sites discussed above (Deep Bay, Duke Point, and Montague Harbor) represent a distinct regional pattern of ground slate use. The technology is present, in very small numbers, in the earliest components of all three sites, which produced dates as early as $\sim 3,600-3,000$ cal BP. However, the technology did not gain "traction" for quite some time; a strong preference for ground slate points did not seem to emerge until around 700-900 cal BP. 
West Vancouver Island:

I will turn now to a more in-depth study of two sites from the west coast of Vancouver Island. It is considerably more difficult to form a picture of the adoption of slate points on this outer coast; as ground slate is less common in the region (McMillan and St. Claire 2005).

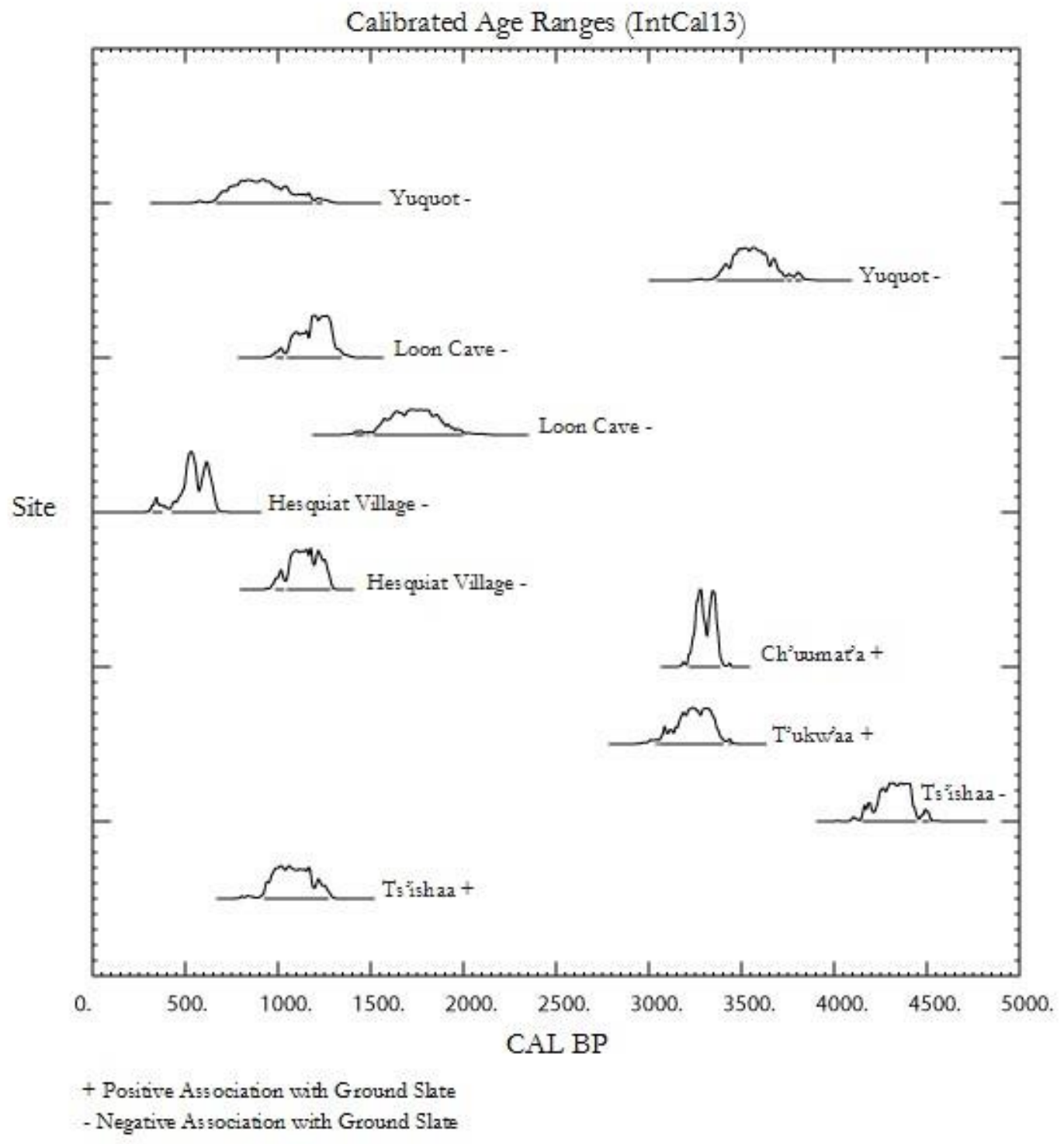

Figure 17: Radiocarbon calibration probability distribution for sites on the west coast of Vancouver Island, sites sorted south to north to south 
Figure 17 gives the impression that Ch'uumat'a (DfSi-4) represents the earliest occurrence of slate in the region, but this may or may not be the case, as I was not able to associate slate points with dated strata to a finer degree than component. A stronger case can be made for nearby 'Ts'ishaa (DfSi-16), a site where ground slate is exceedingly rare (two specimens recovered from over $200 \mathrm{~m}^{3}$ of excavation), but can be closely associated with a date of 3,200-3,400 cal BP $(3,100 \pm 35$ RCY BP). Flaked stone tools are also relatively rare at Ts'ishaa; the assemblage is overwhelmingly composed of bone and shell tools (McMillan and St. Claire 2005).

The site of Yuquot (DjSp-1), on the central outer coast of Vancouver Island, is an even more clear illustration of this assemblage type: no flaked stone points or bifaces were recovered, and only one (entirely unprovenienced) ground slate point. Again, the assemblage is dominated by bone and shell tools, (Folan and Dewhirst 1980), a characteristic shared by all outer coast sites looked at in this study: Hesquiat Village (DiSo-1), Loon Cave (Diso-9) T’ukw'aa (DfSi-23), in addition to those discussed above.

The Shoemaker Bay site (DhSe-2) is unique among the sites looked at in this study. The site is located far up the Alberni Inlet, which opens to the Pacific Ocean at Barkley Sound (the location of both Ch'uumat'a and Ts'ishaa), but is much closer geographically to the inner coast of Vancouver Island. Shoemaker Bay has an extensive ground slate point assemblage, with the multitude of forms (stemmed, unstemmed, triangular) characteristic of Inner Coast assemblages. Shoemaker Bay is also unique in that it is one of the few sites where ground slate points were more abundant in the earlier component than the later. Additionally, flaked stone points increase relative to ground points in this later component. 
This trend should be considered suspect, however, due to unequal samples sizes: component I of Shoemaker Bay (basal date of 3,200-2,800 cal BP) is considerably larger in volume than component II (begins 1,500-1,200 cal BP). Regardless, Shoemaker Bay demonstrates that a fully developed ground slate industry existed in the area prior to about 3,000 years ago (McMillan and St. Claire 1982).

Based on its artifact assemblage, the occupants of Shoemaker Bay are more closely associated with Strait of Georgia peoples than outer coast peoples. However, McMillan and St. Claire (1982) observed clear economic ties between Shoemaker Bay and the west coast of the island.) Occupants of Shoemaker Bay were making use of open-ocean (i.e. Pacific) resources (e.g. deep water fish, seals, etc.) (McMillan and St. Claire 1982:128). This combination of an outer coast economy coupled with an inner coast toolkit is unique among the sites looked at in this study, and has important implications for the question of whether the adoption of certain technologies has more to do with cultural association or functional constraints imposed by prey choices.

\subsection{Was the Fraser Really First?}

I would now like to return to the suggestion posited at the beginning of section 4.5.2; that sites on the Fraser River represent the earliest appearance of ground slate points in the southern region of my study area. The pattern evident in Figures 13 and 14 would seem to bear this out; the data presented in this work demonstrate that ground slate points appear considerably earlier in the archaeological record of Fraser River sites than in the other sites from the southern study area. One conclusion that can be drawn from these data is that the occupants of the Fraser were employing ground slate points well before their coastal neighbors. Below, I outline two other possible explanations. 
The case could be made for independent development of ground slate points in the Fraser River canyon, i.e. a very similar technology to northern ground slate points was developed there, and did not diffuse in from elsewhere. As evidence of this hypothesis, there are the many unique forms that ground slate points take in the region (see above 4.5.2, The Fraser River and Fraser Delta), which could suggest a period of regional experimentation and innovation (Fitzhugh 2001). A more complete sample of Fraser River assemblages would be needed to test this hypothesis. I find this notion intriguing, and worthy of further exploration.

However, I think the most likely explanation as to why ground slate points seem to appear first on the Fraser River is that we are dealing with an issue of sampling bias; we do not have access to the oldest sites in the Strait of Georgia or on Vancouver Island. In a study of late Holocene sea level fluctuations centered on British Columbia's Gulf Islands National Park Reserve, Fedje et al. (2009) determined that sea levels in the region from 13,000 to about 3,000 years ago were significantly lower than at present, owing to a complex interaction of isostatic response to retreating glaciers, an influx of glacial melt water, and the interactions of the Juan de Fuca, Explorer, and Pacific crustal plates (Fedje, et al. 2009:236). While this sea level rise was slight, geologically speaking, ranging from -1.5m RSL (relative sea level) at about 3,700 cal BP to -0.5m RSL at about 1,500 cal BP (Fedje, et al. 2009:239), this is a significant factor when looking for archaeological remains from people who lived directly on the water. Sites with early slate point assemblages such as Pitt River and Esilao were unlikely to have been affected much by this amount of sea level rise at all, given their distance upriver. 
Additionally, the authors carried out archaeological work at a number of sites located in the intertidal zone. Among the artifacts recovered from the Narvaez Bay site (1642T) was a ground slate point (likely triangular) from 80 centimeters below surface. The surface of the Narvaez Bay site sits 1.3 meters below present day high tide. Excavations at 1642T yielded an AMS date of 3,326-3,242 cal BP (Fedje, et al. 2009:244). While still not as early as the dates reported for the Fraser River sites, this shows that slate points were in use in the Strait of Georgia earlier than other sites used in this study (e.g. Deep Bay, False Narrows) might suggest. It also proves that intact archaeological deposits can be recovered from inundated contexts, an exciting possibility.

In a broader study of the British Columbia Coast, Clague et al. (1982) also suggest a rise in sea levels in the Strait of Georgia over the last 13,000 years, continuing until fairly recently. Among other lines of evidence, they cite Montague Harbor, one of the sites used in this study, which produced radiocarbon dates of $730 \pm 130$ to $3,160 \pm 130$, and is now partially inundated at high tide (Clague, et al. 1982:607). The Pacific coast of Vancouver Island, on the other hand, shows evidence for 2-4m of emergence over the last 4,000 years (Clague, et al. 1982:612). Taken together, these studies suggest that we should expect the oldest sites from the Strait of Georgia have been inundated, assuming that people were living on or very near the shoreline, which they almost certainly were. Conversely, early sites on the Fraser River, Fraser Delta, and west coast of Vancouver Island are more likely to be intact.

Given this information, I believe that sites on the Fraser River and in the Fraser Lowlands, as well as those on the east coast of Vancouver Island represent a more or less accurate picture of the earliest appearance of ground slate, whereas slate points would seem to appear erroneously late in the archaeological record of sites in the Strait of Georgia. 


\section{Chapter 5: Conclusions}

The goal of this thesis was threefold: Firstly I set out to assess whether or not ground slate points replace chipped stone technologies. Secondly, I wanted to know when, specifically, ground slate points first appeared in the archaeological record of the Northwest Coast. And finally, I wanted to know what geographic or temporal trends exist regarding the adoption of slate points. To answer these questions, I synthesized information from a collection of site reports, which are the product of both cultural resource management and academic research, and span several decades of work. Additionally, and perhaps just as importantly, these questions have led me to consider the strengths and limitations of working with large datasets drawn from diverse sources. In an effort to quantify the variability inherent in using these diverse sources, I developed and employed a radiocarbon hygiene program, in order to draw conclusions from only the most suitable radiocarbon dates. The issue of inter-site comparability was also considered, by looking at the effects of variable excavations sizes, and accordingly variable sample sizes.

\subsection{Trends}

Based on the aggregate analysis of the 94 components from 50 sites on the Northwest Coast, it has been demonstrated that the practice of manufacturing and employing ground slate points moves south along the Northwest Coast, appearing first in southeast Alaska as early as 7,100-6,100 cal BP, with progressively later earliest appearance dates further south, finally appearing in the archaeological record of the Puget Sound region around 2,900 BP. The sites on the lower Fraser River appear to have the earliest occurrence of ground slate on the southern British Columbia coast, though it is a distinct possibility that sites of comparable age on the Inner Coast (Strait of Georgia) may have been inundated by 
rising sea levels in the last 4,500 years. I postulate that the practice of grinding slate points came into the region via the sheltered waterways of the Inner Coast, and then made its way up the Fraser. However, the data regarding the very earliest appearance of slate points on the inner coast are incomplete, due to rising sea levels. This picture is complicated by such sites such as Deep Bay (DiSe-7) and Duke Point (DgRx-5), which present conflicting and highly variable basal dates for the technology. Despite the variable dates for the earliest occurrence of ground slate points, there is no question that they become most prevalent throughout the Inner Coast by 900-700 cal BP, a fact which should be at the center of further studies on the adoption of ground slate points.

The northern study area presents a less complicated picture of the adoption of ground slate points, though there are notable exceptions to the chronological trend identified in this work, such as the Ground Hog Bay 2 site (49JUN018) which has an anomalously late date for the appearance of slate points.

As to the commonly held notion that ground slate points replace comparable flaked stone tools (whether due to technological superiority, raw material availability, etc.), I have demonstrated that this is only occasionally the case. This thesis has demonstrated that the preference or non-preference for slate tools seems to vary not just temporally, but geographically as well. For example, the occupants of the Slate, Chert, and Sitkalidak Roadcut sites of southeast Alaska all developed a preference for slate points over flaked points through time, but this preference was not always manifested the same way- at Sitkalidak, the number of flaked stone tools fell off precipitously once slate points came into use, whereas at the Slate site, slate tools were simply added to the existing toolkit, rather than replacing flaked points. The occupants of Prince Rupert Harbor seemed to have had no use, 
knowledge, or raw material for making bifacially flaked points. On the other hand, the inhabitants of Haida Gwaii seemed to have no use for slate points, preferring instead bone and shell tools. Likewise, the inhabitants of the Outer Coast of Vancouver Island seemed to have no special preference for slate tools (though it would appear that they too knew how to make them, or could trade from them), also preferring bone and shell. Meanwhile, on the Inner Coast, we see a general replacement of flaked points by ground slate in the archaeological record.

Given these findings, I conclude that on a coast-wide basis, what is observed in the archaeological record is a ground slate emergence rather than a transition. This terminology better suits the variable nature of the diffusion of ground slate points; an emergence suggests that the technology arose or diffused into an area, and may replace a functionally similar technology, or, that it may have been added to the toolkit alongside established technologies. The term "transition" is not so flexible.

I must of course also acknowledge some shortcomings of this study. The case for the north-to-south trend I have identified could be made more robust by the addition of more sites/assemblages for analysis in the northern study area, particularly between Prince Rupert Harbor and Kodiak Island (As I mentioned in section 2.1, there is a distinct lack of sites used in this study in this region). Additionally, there are not as many ground slate negative dates in the southern study area as I would prefer, but, as was mentioned in section 4.4.2, sites such as Glenrose Cannery (Matson 1976), which produced ground slate negative dates of 7,600-9,000 cal BP, do lend some credence to the notion that this trend is not simply an artifact of a paucity of early dates in the southern study area. Additionally, while other sites used in this study, such as St. Mungo Cannery, may lack many radiocarbon dates for these 
early components, make a good case for a true lack of ground slate in the earliest components based on relative stratigraphy.

\subsection{On Radiocarbon}

The experience of putting the radiocarbon hygiene program developed here into practice has led me to some conclusions. Firstly, my system did allow me to support the idea that the north to south trend I identified was a real trend, as the pattern was evident not only with all dates, but also with only the best dates. Further, larger studies of the utility of radiocarbon hygiene (Cooper and Thomas 2012; Pettitt, et al. 2003; Wallace and Green 2012) have found that date selection can have a significant impact on the results of a study. Most archaeologists hold that charcoal collected from a cultural stratum, or ideally from a cultural feature, will produce a "good" date. While this is true to a certain extent, we can do better. The most common failings are to treat all samples as equally reliable, and to prefer charcoal samples by default. Particularly on the Northwest Coast and in the Arctic, researchers must be cognizant of inbuilt age error when employing wood charcoal samples, due to the old wood issues discussed in section 2.3.2. Efforts should be made to identify the species of the sample, to assess whether the longevity of the wood is a problem. Particularly in the Arctic, even this precaution cannot entirely rule out old wood issues, due to the prevalence of driftwood as a fuel source. Accordingly, preference should be given to unmodified terrestrial mammal bone for dating (when available) as 1 . The presence of faunal remains in a site is a direct, fine-grained link between the dated sample and human activity, 2. The material is not subject to unknown marine fractionation, or inbuilt age issues. The exception, of course, would be tools made of terrestrial mammal bone, which could have been curated for a significant about of time, or made from found material. While dating shell 
carries some inherent difficulties, this material can also be an important resource. As with terrestrial mammal bone, shell can represent a very specific temporal event (harvest and consumption), and it is very common in the archaeological record of the Northwest Coast. That being said, extra care must be taken when employing shell samples, as additional data is required to make an accurate marine correction. Researchers should educate themselves on the peculiarities of marine isotope fractionation (e.g. that $\Delta \mathrm{R}$ values vary not just geographically, but throughout time [Deo et al. 2004]).

A further area of concern that I have identified in my research is how closely a date listed in a report could associated with the phenomena under study (in this instance, how closely can a ${ }^{14} \mathrm{C}$ sample be associated with a tool). This is a classic issue of the ambiguity between the targeted event versus the dated event. The best designed radiocarbon hygiene program cannot help you if you have insufficient information about the provenience of your samples. This raises the issue of how important it is for investigators to be as explicit about site stratigraphy when reporting, especially with radiocarbon samples. The most useful reports in this study had the locations of radiocarbon samples, as well as the date they returned, illustrated on the site soil profile figures. Not having radiocarbon dates reported vertical provenience seriously handicaps their utility. The same applies for artifacts, or faunal materials for that matter; oftentimes artifact counts are identified to component rather than strata, (which is somewhat useful), or identified only by which excavation unit they came from (which, chronologically, is not useful at all).

With regard to the utility of the radiocarbon hygiene scoring rubrics, such as the one developed in this work, I do not think that a codified scoring procedure is as important as simply choosing your samples (particularly the material sampled) carefully. The best rubric is 
still subjective, and attaching a numerical value to that subjective decision might suggest a false sense of precision.

\subsection{Implications, Speculations, and Future Directions}

As was discussed in section 1.2, explanations for the emergence of ground slate points generally fall into one of two camps: the availability of raw materials (e.g. Moss 2004, Fitzhugh 2004) versus a technological advantage provided by slate (e.g. C. Ames 2009, Clark 1982). The two are not necessarily mutually exclusive, and this thesis does not settle the matter. However, the chronology of ground slate points developed here does provide an important tool for future studies regarding both of these possible explanations, and thereby aid in untangling the link between aquatic subsistence strategies and technological decision making.

Given the regional nature of the shift to slate discussed above, I am inclined to think that the underlying cause is also something regional (e.g. raw material availability) rather than being due to some intrinsically superior feature of slate points. For example, the sites of Ts'ishaa (DfSi-16) on Barkley Sound on the west coast of Vancouver Island, where ground slate points are rare, and the nearby ground slate-rich site of Shoemaker Bay (DhSe-2) which straddles the Inner and Outer Coasts. The inhabitants of both sites made use of open-ocean resources, but did so with markedly different toolkits. Though the $60 \mathrm{~km}$ paddle from Shoemaker Bay to Ts'ishaa is not an especially difficult journey, taking perhaps 10-20 hours one way (Ames 2002:36), it can certainly be argued that while slate was available to the occupants of Ts'ishaa, bone and shell were certainly more so. The next step in testing this hypothesis would be a geologic study of toolstone sources. If, as Moss (2004) suggests, cryptocrystalline materials are sufficiently rare throughout coastal British Columbia and 
southeast Alaska that access to these resources could become prohibitively difficult, even to people with boats? Does the chronology established in this work correspond to any proxy measure for population density (e.g. number of radiocarbon dates)(Shott 1992)? This leads me to a very important point; current explanations of the causes of the ground slate transition are almost universally predicated on the idea that slate suitable for making tools is widely available. I can so no reason why this notion should not be tested. We must know how common slate toolstone is if this theory is to have any validity.

With regards to technological explanations, it is worth noting the fact that the two most distant regions in this study, Southeast Alaska and the Strait of Georgia, display very similar patterns in their preference for slate points to flaked points, remarkable given the thousands of kilometers and thousands of years that separate these regions. The fact that slate does replace flaked stone points in a number of disparate regions suggests that perhaps we should not rule out technological explanations for the emergence of slate points all together. As I stated in the introduction, slate points are (frequently) not weapons in and of themselves, but rather the mechanism by which complex tools are armed. A broader study of the emergence of complex weapons systems (e.g. harpoons armed with slate or bone points, compound fishhooks, etc.) would likely draw more robust conclusions about the link between aquatic hunter-gatherer economies and technology than the limited study undertaken here. In retrospect, the question of why ground slate points appear to be linked to hunting in aquatic environments is too simplistic. The question that should be asked is what other technological changes are concurrent with the emergence of slate points? This is an easier question to answer, now that the chronology of the emergence of ground slate has been established. This question is in turn a small detail of a larger question: what precipitated 
the development of this complex aquatic hunting gear, if, as it has been supposed, humans have been making use of aquatic resources for time immemorial (e.g. Erlandson 2001)? Another future direction which could build upon this work would be to take the methods employed here and expand the geographic scope. As I stated in the introduction, ground slate points seem to appear first in southeast Alaska, and later in the north, but what is the specific timing of the spread of these tools in the region, and how (or does) that timing relate to important population movements in the arctic (e.g. the Thule migration)? Questions such as these invite new avenues of research into hunter-gatherer maritime adaptation, and the chronology developed here is a tool for exploring some of these questions.

As is the case with many scholarly works, I feel that this thesis has likely raised more questions than it has answered. I consider this a good thing. The value of research can be judged not just by the solutions it presents, and questions it answers, but by whether or not it provides a springboard for a greater understanding of its subject, and by suggesting new lines of inquiry. We now have a clearer picture of the when and where of the emergence of ground slate points, but also, I hope, a solid foundation for answering question of why. 


\section{References Cited}

Acheson, Steven R.

1991 In the wake of the ya'aats' xaatgaay (iron people) : a study of the changing settlement strategies among the Kunghit Haida.

Ackerman, Robert E.

1968 The archaeology of the Glacier Bay region, southeastern Alaska. Washington State University, laboratory of anthropology, Pullman.

Ames, Christopher

2009 From chipped to ground the spatio-temporal systematics of 9,000 years of archaeological change in southwest British Columbia, McGill University, Montreal.

Ames, Kenneth M.

2002 Going by Boat: The Forager-Collector Continuum at Sea. In Beyond foraging and collecting : evolutionary change in hunter-gatherer settlement systems, edited by B. Fitzhugh and J. Habu. Kluwer Academic/Plenum Publishers, New York.

2005 The north coast prehistory project excavations in Prince Rupert Harbour, British Columbia: the artifacts. John and Erica Hedges Ltd., Oxford.

Ames, Kenneth M. and Herbert D. G. Maschner 1999 Peoples of the Northwest Coast : their archaeology and prehistory. Thames and Hudson, New York.

Arnold, Jeanne E.

1992 Complex Hunter-Gatherer-Fishers of Prehistoric California: Chiefs, Specialists, and Maritime Adaptations of the Channel Islands. American Antiquity 57(1):60-84.

Bailey, Geoff

1978 Shell Middens as Indicators of Post-Glacial Economies: A Territorial Perspective. In The Early Post Glacial Settlement of Northern Europe: An Ecological Perspective, edited by P. Mellars. Gerald Duckworth.

Bamforth, Douglas B and Peter Bleed 1997 Technology, flaked stone technology, and risk. Archeological Papers of the American Anthropological Association 7(1):109-139.

Bettinger, Robert L., Bruce Winterhalder and Richard McElreath 2006 A simple model of technological intensification. Journal of archaeological science. 33(4):538. 
Betz, Virginia M.

1991 Sampling, Sample Size, and Artifact Assemblage Size and Richness in Oregon Coast Archaeological Sites. In Prehistory of the Oregon coast: the effects of excavation strategies and assemblage size on archaeological inquiry, edited by R. L. Lyman. Academic Press, San Diego.

Binford, Lewis R. 1980 Willow Smoke and Dogs' Tails: Hunter-Gatherer Settlement Systems and Archaeological Site Formation. American Antiquity 45(1):4-20.

Borden, Charles E.

1962 West Coast Crossties with Alaska. In Prehistoric cultural relations between the Arctic and Temperate zones of North America, edited by J. M. Campbell. Society for American Archaeology, Montreal.

Christensen, Tina and Jim Stafford

2005 Raised Beach Archaeology in Northern Haida Gwaii: Preliminary Results from the Cahoe Creek Site. In Haida Gwaii : buman history and environment from the time of loon to the time of the iron people, edited by D. W. Fedje and R. W. Mathewes. UBC Press, Vancouver.

Clague, John, John R. Harper, R. J. Hebda and D. E. Howes 1982 Late Quaternary sea levels and crustal movements, coastal British Columbia. Can. J. Earth Sci. Canadian Journal of Earth Sciences 19(3):597-618.

Clark, Donald W.

1982 An Example of Technological Change in Prehistory: The Origin of a Regional Ground Slate Industry in South-Central Coastal Alaska. Arctic Anthropology 19(1):103-125.

Clark, Gerald H. 1979 Archaeological testing at the Coffman Cove site, Southeastern Alaska.

Cohen, Mark Nathan

1977 The food crisis in prehistory. Overpopulation and the origins of agriculture.

Collard, Mark, Michael Kemery and Samantha Banks

2005 Causes of toolkit variation among hunter-gatherers: a test of four competing hypotheses. Canadian Journal of Archaeology/Journal Canadien d'Archéologie:1-19.

\section{Cooper, J and KD Thomas}

2012 Constructing caribbean chronologies: comparative radiocarbon dating of shell and wood artefacts from pre-columbian sites in cuba. Archaeometry 54(2):401425 . 
Cutting, C.L

1962 Historical aspects of fish. In Fish As Food V2: Nutrition, Sanitation, and Utilization, edited by G. Borgstrom. vol. 2. Elsevier.

Davis, Stanley D.

1989 The Hidden Falls site, Baranof Island, Alaska. Alaska Anthropological Association, Anchorage, AK.

Deo, Jennie N, John O Stone and Julie K Stein

2004 Building confidence in shell: variations in the marine radiocarbon reservoir correction for the Northwest Coast over the past 3,000 years. American Antiquity:771786.

Dumond, Don E

1968 On the Presumed Spread of Slate Grinding in Alaska. Arctic Anthropology 5(1):82-91.

1987 The Eskimos and Aleuts 180. Thames and Hudson London.

Erlandson, Jon M.

2001 The Archaeology of Aquatic Adaptations: Paradigms for a New Millennium. Journal of Archaeological Research 9(4):287-350.

Fedje, Daryl W., Martin P.R. Magne and Tina Christensen

2005 Test Excavations at Raised Beach Sites in Southern Haida Gwaii and Their Significance to Northwest Coast Archaeology. In Haida Gwaii : buman bistory and environment from the time of loon to the time of the iron people, edited by D. W. Fedje and R. W. Mathewes. UBC Press, Vancouver.

Fedje, Daryl W. and Rolf W. Mathewes

2005 Haida Gwaii : human history and environment from the time of loon to the time of the iron people. UBC Press, Vancouver.

Fedje, Daryl W., Ian D. Sumpter and John R. Southon

2009 Sea-levels and Archaeology in the Gulf Islands National Park Reserve.

Canadian Journal of Archaeology / Journal Canadien d'Archéologie 33(2):234-253.

Fitzhugh, Ben

2001 Risk and Invention in Human Technological Evolution. Journal of Anthropological Archaeology 20(2):125-167.

2004 Colonizing the Kodiak Archipelago: Trends in Raw Material Use and Lithic Technologies at the Tanginak Spring Site. Arctic Anthropology 41(1):14-40. 
Folan, William J. and John Dewhirst

1980 The Yuquot project. National Historic Parks and Sites Branch, Parks Canada, Environment Canada, Ottawa.

Friesen, T Max and Charles D Arnold 2008 The timing of the Thule migration: new dates from the western Canadian Arctic. American Antiquity:527-538.

Haggarty, James C. and John H. W. Sendey 1976 Test excavation at the Georgeson Bay Site, Gulf of Georgia region, British Columbia. British Columbia Provincial Museum, Victoria, B.C.

Hanson, Gordon William 1973 The Katz site : a prehistoric pithouse settlement in the lower Fraser Valley, British Columbia.

Lyman, R. Lee

1991 Prehistory of the Oregon coast: the effects of excavation strategies and assemblage size on archaeological inquiry. Academic Press, San Diego.

Mason, Robert Andrew

1994 Hatzic Rock site a Charles Culture settlement.

Matson, R. G.

1976 The Glenrose Cannery site. National Museums of Canada, Ottawa.

Matson, R. G. and Gary Graham Coupland 1995 The prehistory of the Northwest Coast. Academic Press, San Diego.

McGhee, Robert 2001 Ancient people of the Arctic. UBC Press.

McMillan, Alan D. and Denis E. St. Claire 1982 Alberni prehistory : archaeological and ethnographic investigations on Western V ancouver Island. Theytus Books, Penticton, B.C.

1991 The Toguaht Archaeological Project: Report on the 1991 Field Season. The British Columbia Heritage Trust Archaeology Branch: Ministry of Tourism Toquaht Band- Ucluelet, B.C.

1992 The Toquaht Archaeological Project: Report on the 1992 Field Season. The British Columbia Heritage Trust Archaeology Branch: Ministry of Tourism Toquaht Band- Ucluelet, B.C. 
1994 The Toquaht Archaeological Project: Report on the 1994 Field Season. The British Columbia Heritage Trust Archaeology Branch: Ministry of Tourism Toquaht Band- Ucluelet, B.C.

2005 Ts'ishaa : archaeology and ethnography of a Nuu-chah-nulth origin site in Barkley Sound. Archaeology Press, Dept. of Archaeology, Simon Fraser University, Burnaby, B.C.

McNeely, R. , A. S. Dyke and J. R. Southon

2006 Canadian marine reservoir ages, preliminary data assessment.

Geological Survey Canada.

Mitchell, Donald H.

1963 Esilao, a pit house village in the Fraser Canyon, British Columbia.

1971 Archaeology of the Gulf of Georgia area, a natural region and its culture types. Syesis 4(Supplement 1).

Monks, Gregory G.

1977 An examination of relationships between artifact classes and food resource remains at Deep Bay, DiSe 7.

Morlan, Richard E.

2005 Canadian Archaeological Radiocarbon Database. Canadian Museum of Civilization.

Moss, Madonna L.

2004 The Status of Archaeology and Archaeological Practice in Southeast Alaska in Relation to the Larger Northwest Coast. Arctic Anthropology 41(2):177-196.

Murray, Rebecca A.

1982 Analysis of artifacts from four Duke Point Area sites, near Nanaimo, BC: an example of cultural continuity in the southern Gulf of Georgia region. National Museums of Canada, Ottawa.

Orchard, Trevor Jonathan 2007 Otters and urchins: continuity and change in Haida economy during the Late Holocene and maritime fur trade periods. ProQuest.

Pettitt, P. B., W. Davies, C. S. Gamble and M. B. Richards 2003 Palaeolithic radiocarbon chronology: quantifying our confidence beyond two half-lives. Journal of Archaeological Science 30(12):1685-1693.

Renouf, M. A. P.

1991 Sedintary Hunter-Gatherers: A case for Northern Coasts. In Between bands and states, edited by S. A. Gregg. Southern Illinois Univ. 
Ritchie, William A.

1969 Ground Slates: East and West. American Antiquity 34(4):385-391.

Sauer, Carl O

1962 Seashore-primitive home of man? Proceedings of the American Philosophical Society:41-47.

Severs, Patricia D. S.

1974 Archaeological Investigations at Blue Jackets Creek, F1Ua-4, Queen Charlotte Islands, British Columbia, 1973. Bulletin (Canadian Archaeological Association) (6):163-205.

Shott, Michael J

1992 Radiocarbon dating as a probabilistic technique: the Childers site and Late Woodland occupation in the Ohio Valley. American Antiquity:202-230.

Simonsen, Bjorn O.

1973 Archaeological investigations in the Hecate Strait-Milbanke Sound area of British

Columbia. National Museum of Man, Ottawa.

Spriggs, Matthew and Atholl Anderson

1993 Late colonization of east Polynesia. Antiquity 67(255):200-217.

Stuiver, Minze, Paula J. Reimer and Ron Reimer

2005a Calib 6.1.0. Manual. 5 ed.

2005b Calibration Software: Calib 6.1.0.

Wallace, Rod and Roger C Green

2012 Reassessing the radiocarbon chronology of the Maioro site (R13/1):

Northern Waikato, New Zealand.

Waterbolk, H.T.

1971 Working with radiocarbon dates. Proceedings of the Proceedings of the prehistoric society 37:15-33.

Yesner, David R

1980 Maritime hunter-gatherers: ecology and prehistory. Current Anthropology:727-

750.

1987 Life in the garden of Eden: Causes and Consequences of the Adoption of Marine Diets by Human Societies. . In Food and evolution: Toward a theory of human food habits, edited by M. Harris and E. B. Ross. Temple University Press. 


\section{Appendix A: Artifact Counts by Site}

GSL: Ground slate points, longer than $10 \mathrm{~cm}$.

GSS: Ground Slate points, shorter than $10 \mathrm{~cm}$.

GST: Ground slate points, stemmed base.

GSU: Ground slate points, undifferentiated (metric attributes not available).

GS Total: Total of all slate point categories.

GSNP: ground slate, non-point (e.g. blades, knives, single edge tools, etc. that cannot be definitively termed projectile points).

FSP: Flaked (chipped) stone points.

FSB: Flaked (chipped) stone bifaces which cannot be that cannot be definitively termed projectile points.

FS Total: Total of all Flaked (chipped) stone categories.

\begin{tabular}{|c|c|c|c|c|c|c|c|c|c|c|}
\hline Site Name & $\begin{array}{c}\text { Site } \\
\text { Number }\end{array}$ & GSL & GSS & GST & GSU & $\begin{array}{l}\text { GS } \\
\text { Total }\end{array}$ & $\begin{array}{c}\text { GSN } \\
\text { P }\end{array}$ & FSP & FSB & $\begin{array}{c}\text { FS } \\
\text { Total }\end{array}$ \\
\hline Baldwin & GbTo 36 & 0 & 0 & 0 & 16 & 16 & 0 & 0 & 0 & 0 \\
\hline Belcarra Park & $\operatorname{DhRr} 6$ & 0 & 51 & 2 & 14 & 67 & 65 & 130 & 32 & 162 \\
\hline Blue Jackets Creek & F1ua-4 & & & & + & + & + & $+?$ & + & $?$ \\
\hline Boardwalk & GbTo 31 & 0 & 0 & 0 & 50 & 50 & 0 & 0 & 0 & 0 \\
\hline Boardwalk & GbTo 31 & & & & 144 & 144 & 2 & 0 & 0 & 0 \\
\hline British Camp & $45 \mathrm{SJ} 24$ & 0 & 0 & 0 & 0 & 0 & 9 & 28 & 5 & 33 \\
\hline Buckley Bay & DjSf-13 & & & & 7 & 7 & 6 & 0 & 1 & 1 \\
\hline Cahoe Creek & FiUb 10 & & & & 0 & 0 & 0 & 0 & 2 & 2 \\
\hline Ch'uumat'a & DfSi 4 & & & & 2 & 2 & 2 & 0 & 1 & 1 \\
\hline Chert Site & 49AFO106 & & & & 31 & 31 & 3 & 69 & 234 & 303 \\
\hline Coffman Cove & 49PET067 & & & & 10 & 10 & 0 & 0 & 1 & 1 \\
\hline $\begin{array}{l}\text { Crescent Beach } \\
\text { Decatur Island }\end{array}$ & DgRr1 & & & & 0 & 0 & 0 & 9 & 3 & 12 \\
\hline $\mathrm{I} / \mathrm{II}$ & $45 \mathrm{SJ} 165$ & & & & 3 & 3 & 2 & 4 & 17 & 21 \\
\hline Deep Bay & DiSe-7 & 0 & 6 & 0 & 9 & 15 & 8 & 22 & 0 & 22 \\
\hline Dionision Point & DgRv-3 & & & & + & & + & + & + & \\
\hline Duke Point & DgRx 5 & 0 & 0 & 0 & 42 & 42 & 36 & 44 & 2 & 46 \\
\hline Esilao & DjRi-5 & 2 & 0 & 0 & 2 & 2 & 232 & 113 & 144 & 224 \\
\hline False Narrows & DgRw 4 & 14 & 16 & 5 & 21 & 56 & 125 & 75 & 76 & 151 \\
\hline Garden Island & GbTo 23 & & & & 14 & 13 & 1 & 0 & 0 & 0 \\
\hline Georgeson Bay & DfRu 25 & & & & 24 & 24 & 14 & 19 & 4 & 24 \\
\hline Glenrose Cannery & $\operatorname{DgRr} 6$ & & & & 14 & 13 & 33 & 40 & 72 & 112 \\
\hline $\begin{array}{l}\text { Grant Anchorage } \\
\text { Ground Hog Bay }\end{array}$ & FcTe-4 & 0 & 0 & 0 & 0 & 0 & 0 & 4 & 3 & 7 \\
\hline 2 & 49JUN018 & 2 & 0 & 0 & 0 & 2 & 5 & 0 & 3 & 3 \\
\hline Hatzic Rock & DgRn-23 & 3 & 0 & 0 & 0 & 3 & ? & 42 & 0 & 0 \\
\hline Hesquiat Village & DiSo 1 & 0 & 0 & 0 & 0 & 0 & 0 & 1 & 0 & 0 \\
\hline Hidden Falls & 49SIT119 & 13 & 1 & 2 & 83 & 99 & 23 & 0 & 2 & 2 \\
\hline Indian Island & 45JE16 & 0 & 0 & 0 & 0 & 0 & 1 & 1 & 0 & 1 \\
\hline Katz Site & DiRj 1 & & & & 17 & 17 & 474 & 71 & 53 & 124 \\
\hline
\end{tabular}




\begin{tabular}{|c|c|c|c|c|c|c|c|c|c|c|c|}
\hline Kilgii Gwaay & $1325 \mathrm{~T}$ & 0 & 0 & & 0 & 0 & 0 & 0 & 1 & 1 & 2 \\
\hline Kitandach & GbTo 34 & & & & & 8 & 8 & 3 & 0 & 0 & 0 \\
\hline Lachane & GbTo 33 & & & & & 6 & 6 & 1 & 0 & 0 & 0 \\
\hline $\begin{array}{l}\text { Loon Cave } \\
\text { Montague }\end{array}$ & DiSo 9 & 0 & 0 & & 0 & 0 & 0 & 0 & 0 & 0 & 0 \\
\hline Harbour & DfRu 13 & 0 & 18 & & 3 & 8 & 29 & 10 & 26 & 9 & 35 \\
\hline Narvaez Bay & $1642 \mathrm{~T}$ & 0 & 1 & & 0 & 0 & 1 & 0 & 0 & 0 & 0 \\
\hline O'Connor & EeSu 5 & 0 & 2 & & 0 & 0 & 3 & 0 & 0 & 3 & 3 \\
\hline Pitt River & DhRq-21 & & & & 1 & 11 & 12 & 13 & 15 & 178 & 193 \\
\hline Richardson Island & $1127 \mathrm{~T}$ & 0 & 0 & & 0 & 0 & 0 & 0 & 0 & 55 & 55 \\
\hline Sequim Bypass & 45CA426 & & & & & 17 & 17 & 1 & 16 & 60 & 76 \\
\hline Shoemaker Bay & DhSe-2 & & & & & 92 & 92 & 8 & 35 & 7 & 42 \\
\hline Sitkalidak Roadcut & 49KOD438 & & & & & 40 & 40 & 3 & 11 & 18 & 29 \\
\hline $\begin{array}{l}\text { Slate Site } \\
\text { St. Mungo }\end{array}$ & 49AFO109 & & & & 10 & 135 & 145 & 7 & 13 & 0 & 13 \\
\hline Cannery & $\mathrm{DgRr}-2$ & & & & & + & + & & & & \\
\hline T’ukw’aa & DfSi 23 & & & & & 3 & 3 & 0 & 0 & 0 & 0 \\
\hline Tanginak Spring & $49 \mathrm{KOD} 481$ & 0 & 0 & & 0 & 0 & 0 & 0 & 154 & 34 & 188 \\
\hline Tsawwassen & DgRs 2 & 0 & 0 & & 0 & 11 & 11 & 91 & 21 & 14 & 35 \\
\hline Ts'ishaa & DfSi 16 & 0 & 0 & & 4 & 2 & 6 & 2 & 0 & 2 & 1 \\
\hline West Point & $45 \mathrm{KI} 428 / 9$ & 0 & 1 & & 0 & 0 & 1 & 1 & 27 & 52 & 77 \\
\hline Wet Creek & HiTp 1 & & & & & 1 & 1 & 0 & 19 & 443 & 462 \\
\hline Yuquot & $\mathrm{DjSp} 1$ & 0 & 0 & & 0 & 0 & 0 & 0 & 0 & 0 & 0 \\
\hline
\end{tabular}

